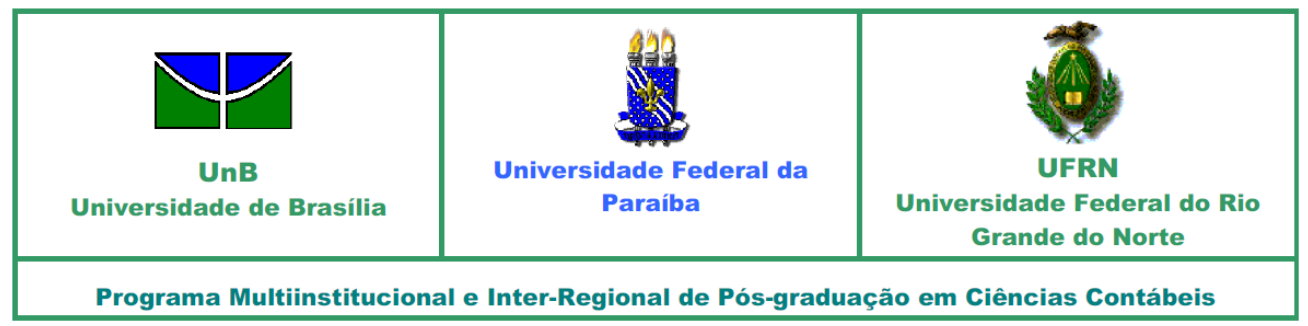

\title{
A TRAJETÓRIA DO CONTROLLER E O DESENVOLVIMENTO DE SUAS COMPETÊNCIAS
}

ROBERTO JOSÉ VIEIRA DE SOUSA LIMA

\author{
NATAL/RN
}


ROBERTO JOSÉ VIEIRA DE SOUSA LIMA

\title{
A TRAJETÓRIA DO CONTROLLER E O DESENVOLVIMENTO DE SUAS COMPETÊNCIAS
}

\begin{abstract}
Dissertação apresentada ao Programa Multiinstitucional e Inter-regional de Pósgraduação em Ciências Contábeis da Universidade de Brasília, Universidade Federal da Paraíba e Universidade Federal do Rio Grande do Norte, como requisito à obtenção do título de Mestre em Ciências Contábeis.

Orientadora: Profa. Dra. Aneide Oliveira Araujo
\end{abstract}




\section{A TRAJETÓRIA DO CONTROLLER E O DESENVOLVIMENTO DE SUAS COMPETÊNCIAS}

Dissertação apresentada como requisito parcial à obtenção do título de Mestre em Ciências Contábeis do Programa Multiinstitucional e Inter-regional de Pós-graduação em Ciências Contábeis da Universidade de Brasília, Universidade Federal da Paraíba e Universidade Federal do Rio Grande do Norte.

Data da aprovação: 01/02/2016

BANCA EXAMINADORA:

Profa. Dra. Aneide Oliveira Araújo

Orientadora

(UnB/UFPB/UFRN)

Prof Dr. Adilson de Lima Tavares

Membro Examinador Interno

(UnB/UFPB/UFRN)

Prof. Dr. Fábio Frezatti

Membro Examinador Externo

(USP)

NATAL/RN

2016 
Lima, Roberto José Vieira de Sousa.

A trajetória do controller e o desenvolvimento de suas competências / Roberto José Vieira de Sousa Lima. - Natal, 2016.

77f: il.

Orientadora: Profa. Dra. Aneide Oliveira Araújo.

Dissertação (Mestrado em Ciências Contábeis) - Universidade Federal do Rio Grande do Norte. Centro de Ciências Sociais Aplicadas. Programa Multiinstitucional e Inter-regional de Pós-graduação em Ciências Contábeis da Universidade de Brasília, Universidade Federal da Paraíba e Universidade Federal do Rio Grande do Norte.

1. Contabilidade - Dissertação. 2. Controlador - Competência profissional Dissertação. 3. Controller - Aspectos profissionais - Dissertação. 4. Desenvolvimento de competências - Dissertação. I. Araújo, Aneide Oliveira. II. Universidade Federal do Rio Grande do Norte. III. Universidade de Brasília. IV. Universidade Federal da Paraíba. V. Título. 
Aos meus pais, D. Fátima e S. Didi.

Por nós e para vocês, sempre. 


\section{AGRADECIMENTOS}

Em primeiro lugar, gostaria de agradecer a minha orientadora Profa. Aneide, não somente pelas orientações, dedicação e paciência com o meu trabalho, mas também por ter aberto para mim as portas da UFRN. Também agradecer pelas longas conversas sobre o ofício de lecionar. Comigo ficam os ensinamentos de uma professora dedicada e, acima de tudo, apaixonada pelo que faz. Espero ter deixado a energia de quem está iniciando uma carreira e a vontade de aprender e evoluir sempre.

Agradecer ao Programa Multiinstitucional e Interregional de Pós-Graduação em Ciências Contábeis - PPGCC UnB/UFPB/UFRN pela oportunidade e a confiança. Também, a todos os seus professores com os quais mantive contato neste tempo: Edilson Paulo, Wenner, Paulo Cavalcanti, Paulo Aguiar, Marcia, Adilson, Aldo, Adriano, Paulo Hamilton e Erivan. Vi este programa nascer quando ainda era graduando em Ciências Contábeis pela UFPE e entendo sua importância para a nossa região. Fazer parte dele, na sua última turma, é algo que ainda me deixa muito feliz. Aproveito para agradecer à Coordenação de Aperfeiçoamento de Pessoal de Ensino Superior (CAPES) pela bolsa de estudos concedida.

Aos amigos da turma de Mestrado, minha gratidão e respeito. Como eu disse na última aula, foi muito bom ter vocês como companheiros nessa jornada. Inajá, Ana Karla, Marcelo, Polyandra, Victor Ranieri, João Marcelo, Fabiana, Camila, Nyalle, Leandro, Agamenon, Victor Godeiro e Carlos André, aprendi muito com todos, sem exceção. Aos quatro últimos amigos, noites de segunda-feira sempre me lembrarão de vocês.

Aos amigos fora do Mestrado, gostaria de dizer que parte de todos vocês também está nesse trabalho. Sou muito orgulhoso dos amigos que fiz e continuo fazendo: Pyedas, PJ's, RPGistas, Pernambucanos, Potiguares, alunos e professores da Estácio, obrigado por fazerem parte da minha vida.

Agradeço aos meus familiares todo o suporte e a força necessária para seguir nessa caminhada. Aos meus pais e irmãos gostaria, antes de agradecer, pedir desculpas pela ausência. Nesses últimos dois anos, a distância física foi acentuada pela falta de tempo. Enfim, o esforço valeu a pena, mais um objetivo concluído. Ao meu Pai e minha Mãe agradeço especialmente o empenho e dedicação de uma vida por nós. Também, por nos ensinarem que, mesmo com todas as dificuldades, é preciso lutar até o fim. Aos meus irmãos, Edinha, Léo e Keka, minha eterna admiração e carinho. Tenho um orgulho danado de vocês. Ainda em Pernambuco, agradeço a Vovó Edna, Cacá, Tio Roger, Paulinha, Thais, Thiago e a todos que se juntaram a esta família. Da minha família do RN, agradeço o acolhimento, a 
ajuda nos momentos difíceis e os inúmeros momentos de felicidade. S. Ramalho, D. Zilda (esses dois em especial), Samuel, Andrea, Tiago e Vinicius (meu compadre e amigo de uma vida), muito obrigado. Deixo também um beijo para os pequenos queridos: João Pedro, Victor, Lucas, Miguel, Luiz Davi, Mariana, Leonardo e Alice. Participar da vida de vocês é um grande barato.

Por fim, vem o agradecimento mais especial. Ela que é a grande entusiasta deste trabalho, quem embarcou nessa aventura sem relutar. Ludmila, muito obrigado por tudo nessa jornada. Sem sua compreensão, apoio nos momentos de dificuldade e carinho, dificilmente eu estaria escrevendo essas linhas. Sei que ainda estamos no começo, muitos outros desafios e jornadas virão. Em breve seremos três. Mas, com você, tudo fica mais fácil e mais apaixonante de se realizar. Amo-te. 
Um passo à frente

E você não está mais no mesmo lugar

Chico Science e Nação Zumbi 


\section{RESUMO}

Visto que toda pessoa é o resultado de suas vivências passadas e atuais, torna-se possível ponderar que as competências adquiridas por um Controller estão intimamente relacionadas com sua trajetória profissional. Ante o exposto, esta pesquisa tem como objetivo investigar os aspectos da trajetória do Controller e sua contribuição para o desenvolvimento de competências e atuação profissional. Quanto aos objetivos, este estudo se caracteriza como descritivo, já com relação aos procedimentos, levantamento ou survey e, no que se refere à abordagem do problema, se caracteriza como qualitativo. O procedimento de coleta se deu através de um questionário eletrônico, estruturado em três blocos: Competência dos Controllers em escala de importância; Experiências essenciais no desenvolvimento de um Controller; e Perfil do respondente. A amostra foi formada a partir de uma rede social profissional, e obtiveram-se respostas de 208 profissionais, de diferentes níveis hierárquicos, tempos de carreira diversos e de todas as regiões do país. Os resultados apontaram que, com relação às competências indispensáveis, os respondentes indicaram a capacidade analítica, domínio de contabilidade e finanças, planejamento, trabalho em equipe e visão estratégica. Como principal vivência para o desenvolvimento das competências necessárias, estes Controllers apontaram as experiências profissionais. Com relação à trajetória profissional, observou-se uma tendência crescente entre o tempo de carreira e a quantidade de Controllers ocupando níveis hierárquicos mais elevados nas empresas. Ademais, verifica-se que para chegarem a este cargo, os profissionais devem valorizar um conjunto de experiências, tais como cursos de pós-graduação bem avaliados academicamente e atuação em áreas, para além da contabilidade, como de auditoria e finanças. Desta maneira, pode-se concluir que vivências acadêmicas e profissionais, de naturezas diversas, podem contribuir de forma incisiva para o desenvolvimento das competências essenciais as suas atividades.

Palavras-Chave: Desenvolvimento de Competências. Trajetória Profissional. Controller. 


\begin{abstract}
Since every person is a result of your past and current experiences, we can consider that the skills developed by a Controller are closely related to his professional career. Based on this, the research aims to discuss trajectory's aspects of the Controller and its contribution to the development of skills and professional performance. This is a descriptive study in its aim, a survey in respect to its procedures and a qualitative one in regard to the approach of the problem. The collection procedure was made through an electronic questionnaire, structured in three blocks: Controllers's competence in order of importance; Essential experiences in developing a Controller; and respondent profile. The sample was defined from a professional social network which provided 208 responses, in different hierarchical levels and career times and from all regions of the country. The main results points that respondents evaluate analytical skills, accounting and finance domain, planning, teamwork and strategic vision as necessary skills. Also, as main experience for developing the necessary skills, these Controllers pointed professional experiences. Regarding professional career, there was a growing trend among career time and the amount of Controllers occupying higher hierarchical levels in companies. Moreover, it turns out that to reach this position, professionals should value a set of experiences, such as qualified postgraduate courses and performance in areas other than accounting, like auditing and finance. Thus, we can conclude that different types of academic and professional experiences can contribute incisively to the development of key competencies of its activities.
\end{abstract}

Key-words: Competency Development. Professional Career. Controller. 


\section{LISTA FIGURAS}

Figura 1: Competências como fonte de valor para o individuo e para a organização ............. 22

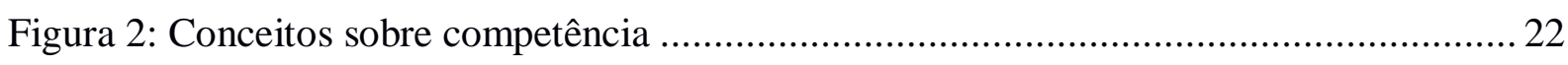

Figura 3: Noções de qualificação e competências e características principais dos respectivos

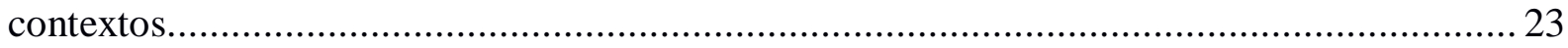

Figura 4: Visão geral de modelo de tarefas da Controladoria ............................................ 33 


\section{LISTA DE GRÁFICOS}

Gráfico 1: Sexo dos respondentes.......................................................................... 42

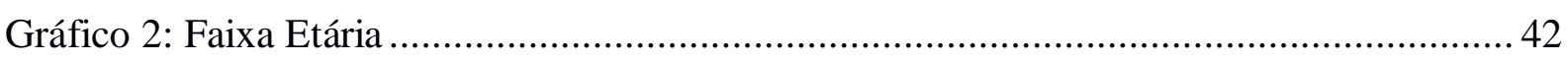

Gráfico 3: Formação de pós-graduação, por nível do curso ............................................. 44

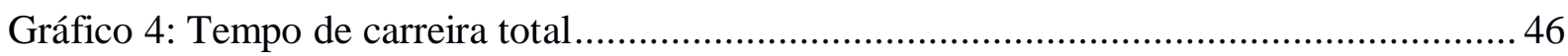

Gráfico 5: Tempo de carreira como Controller ............................................................... 46

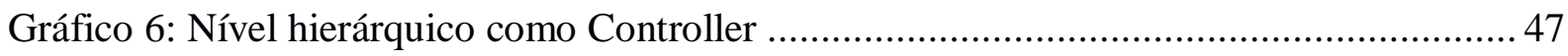

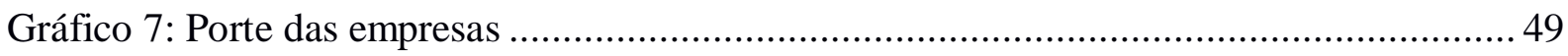

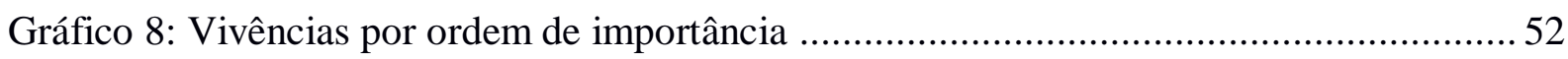

Gráfico 9: Tempo de carreira profissional X Nível Hierárquico ........................................ 59

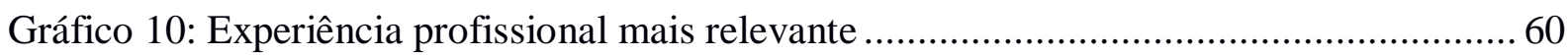




\section{LISTA DE QUADROS}

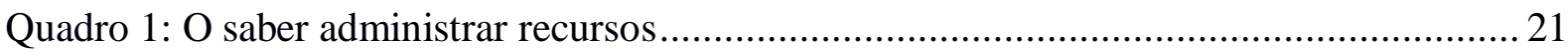

Quadro 2: Recursos incorporados ao profissional ........................................................ 24

Quadro 3: Processo de desenvolvimento de competências ............................................. 25

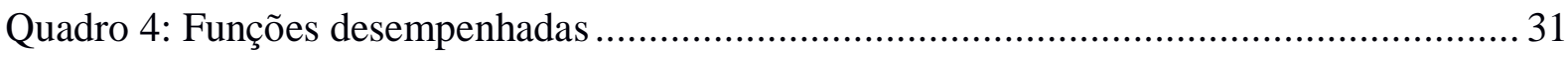

Quadro 5: Funções da Estrutura Conceitual Básica da Controladoria ................................... 32

Quadro 6: Perspectivas e funções básicas da Controladoria ............................................... 31

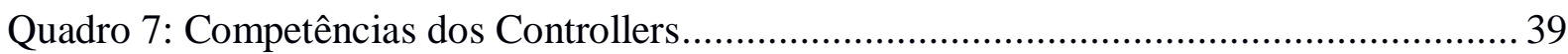

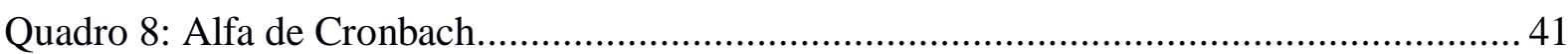




\section{LISTA DE TABELAS}

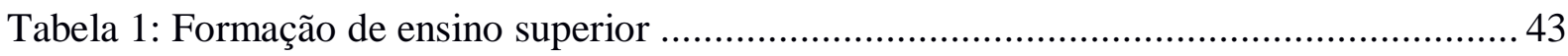

Tabela 2: Formação de pós-graduação......................................................................... 44

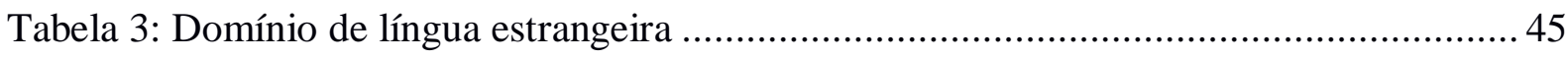

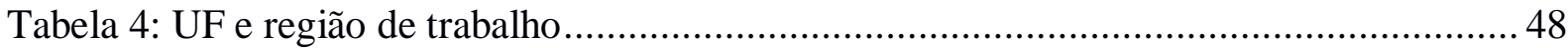

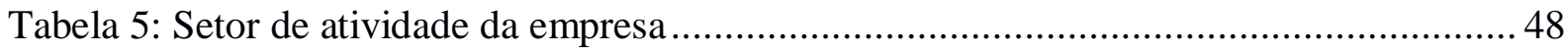

Tabela 6: Competências dos Controllers em grau de importância ...................................... 50

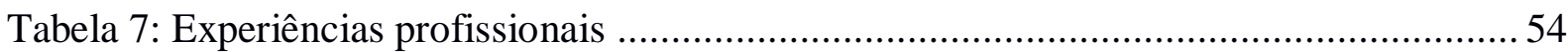

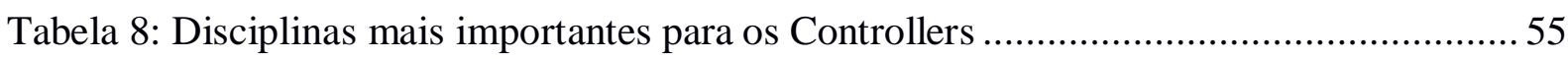

Tabela 9: Formação graduada x Porte da empresa ....................................................... 56

Tabela 10: Formação de pós-graduação x Nível hierárquico como Controller....................... 57

Tabela 11: Formação de pós-graduação x Porte da empresa ................................................. 58

Tabela 12: Domínio de idiomas X Porte da empresa ........................................................... 59

Tabela 13: Experiência profissional mais valiosa X Nível hierárquico ................................. 61 


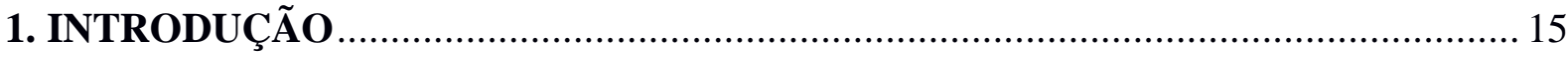

1.1 CONTEXTUALIZAÇÃO E PROBLEMA ............................................................. 15

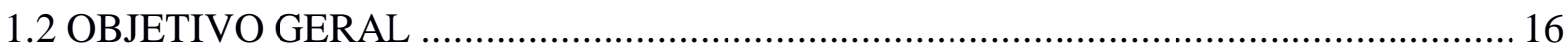

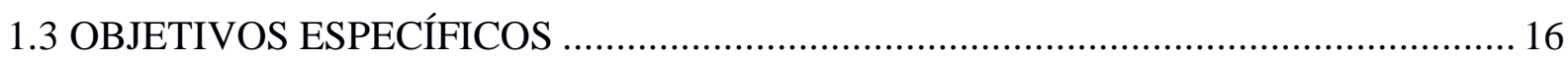

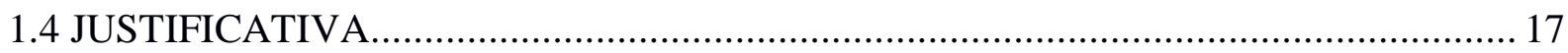

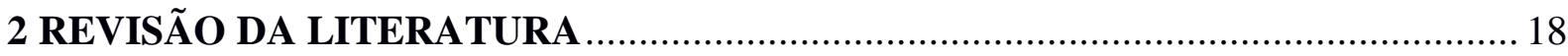

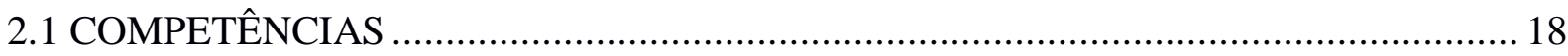

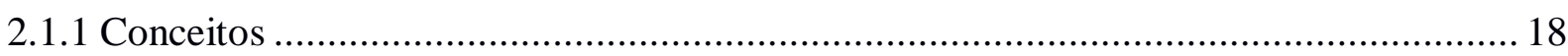

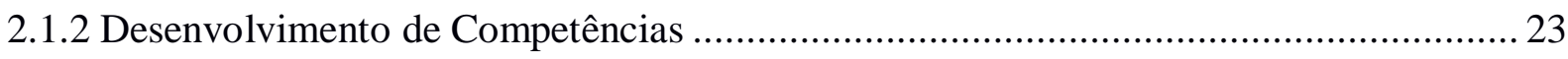

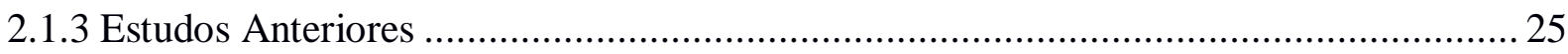

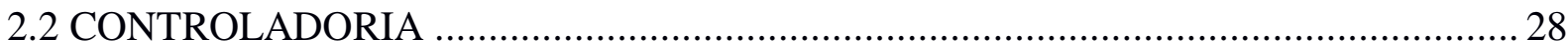

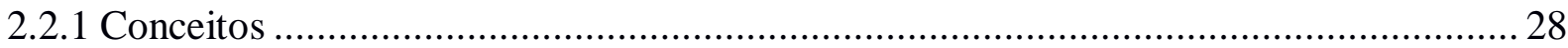

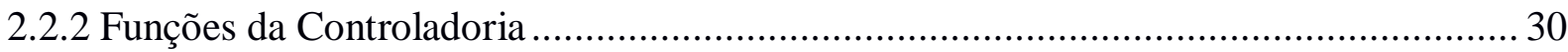

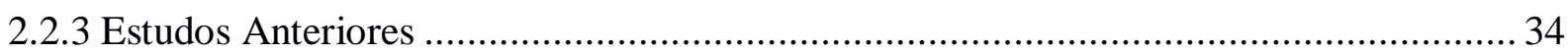

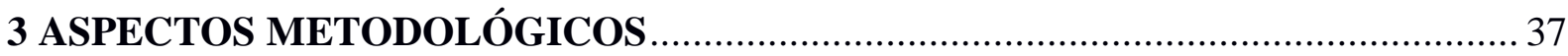

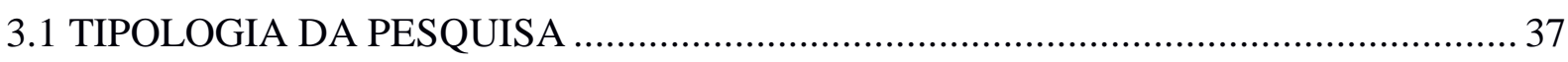

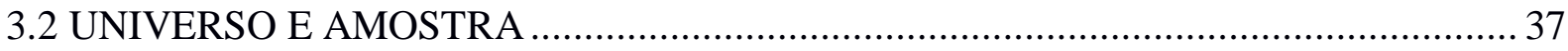

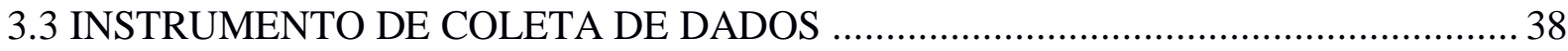

3.3 PROCEDIMENTOS DE ANÁLISE DOS DADOS …................................................ 40

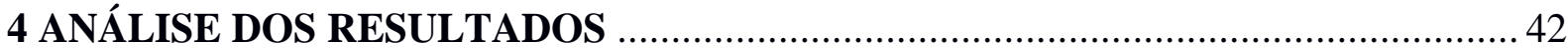

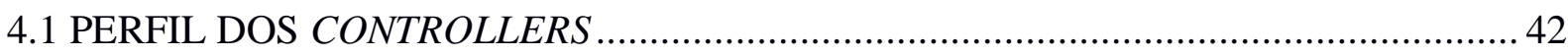

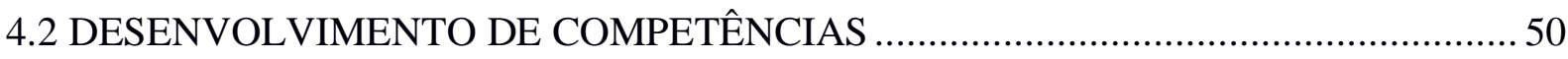

4.2 TRAJETÓRIA ACADÊMICA E PROFISSIONAL DOS CONTROLLERS .................... 55

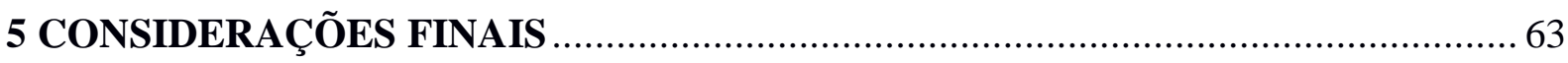

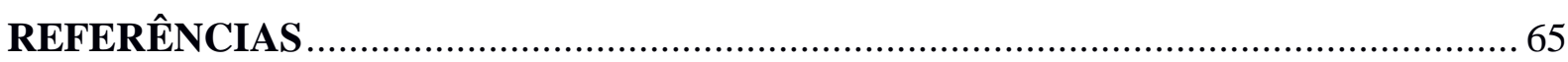

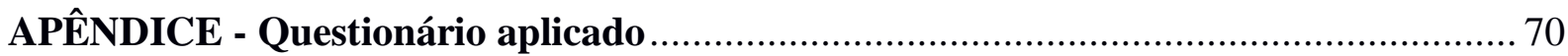




\section{INTRODUÇÃO}

\subsection{CONTEXTUALIZAÇÃO E PROBLEMA}

No atual contexto de alta competitividade da economia global, mudanças sociais, políticas, econômicas e tecnológicas são capazes de impactar rápida e diretamente a dinâmica das organizações. Ou seja, para se manterem ativas nesta conjuntura de negócios, as empresas precisam reagir a estas variações na mesma frequência e velocidade em que elas acontecem. Para isso, além de uma estrutura operacional eficiente, as empresas necessitam de informações qualificadas que auxiliem no processo de gestão.

Neste cenário, a Controladoria assume um importante papel, pois além de ter responsabilidade sobre a gestão da informação, possui uma visão integral das empresas e dos seus objetivos. Segundo Machado et al. (2010), sua origem se dá a partir de conceitos fundamentais da contabilidade e aponta para atividades de suporte informacional, controle interno, planejamento tributário, elaboração do orçamento e medidas operacionais. Assim, além de suprir a necessidade da gestão por relatórios para a tomada de decisão, esta passa a atuar mais diretamente no planejamento das ações das empresas.

O profissional responsável por compilar estas necessidades informacionais e de gestão, no Brasil, é o Controller. Conforme Figueiredo e Caggiano (2004), seu papel é cuidar da continuidade das organizações, viabilizando a coesão entre as atividades desenvolvidas pelos setores, por meio de um eficiente sistema de informações. Ou seja, ele é o profissional que tem a responsabilidade de coordenar as ações da empresa em busca de melhores resultados (GOMES; SOUZA; LUNKES, 2014).

Porém, para o Controller, atuar e contribuir neste cenário são tarefas com certo grau de complexidade. Conforme explicam Lunkes, Schnorrenberger e Rosa (2013), apesar de a Controladoria ser alvo de estudo desde a primeira metade do século XX, há ainda uma série de conceitos e visões insuficientes, confusas, contraditórias e não consensuais com relação às suas funções, gerando dificuldades na consolidação do ramo de conhecimento em si. Vários estudos recentes têm buscado identificar e analisar estas funções, tais como o de Lunkes, Gasparetto e Schnorrenberger (2010), Richartz et al. (2012), Lunkes, Schnorrenberger e Rosa (2013), Gomes, Souza e Lunkes (2014), Dal Vasco, Daniel e Tarifa (2014), entre outros.

Esta dificuldade na consolidação do ramo de conhecimento reflete-se na atuação do profissional, pois as competências requeridas por uma empresa de um Controller dependem das funções que o mesmo irá desempenhar. Seguem alguns exemplos de competências 
requeridas deste profissional: conhecimento em contabilidade e finanças, domínio de ferramentas de planejamento e controle, manejo de sistemas de informação, gerenciar orçamentos, além de habilidades de trabalho em equipe, liderança, comunicação oral, entre outros (CARDOSO et al., 2010, MACHADO et al., 2010; FERREIRA, 2011; ARAÚJO, CALLADO e CAVALCANTI, 2014).

Desta maneira, em razão de existirem empresas com propósitos e características bem diferentes, não é difícil considerar que as competências requeridas de um Controller, no atual contexto do mercado de trabalho, são bem diversas. Neste sentido, Ferreira (2011) explica que características como setor de atividade e porte da empresa influenciam no tipo de competência requerida e, consequentemente, na forma de atuação do profissional.

Ante o exposto, e visto que toda pessoa é o resultado de suas vivências passadas e atuais, torna-se possível ponderar que as competências adquiridas por um Controller estão intimamente relacionadas com sua trajetória profissional. Conforme explica Dutra (2004), como a trajetória profissional direciona o desenvolvimento de um indivíduo, é possível relacioná-la com as competências adquiridas por determinado profissional. Neste sentido, surge o seguinte problema de pesquisa: Quais vivências da trajetória do Controller contribuem para o desenvolvimento de competências e na atuação profissional?

\subsection{OBJETIVO GERAL}

Com base no problema de pesquisa acima exposto, têm-se o seguinte objetivo geral para esta pesquisa: Investigar os aspectos da trajetória do Controller e sua contribuição para o desenvolvimento de competências e atuação profissional.

\subsection{OBJETIVOS ESPECÍFICOS}

Como objetivos específicos, para atender ao objetivo geral, e, consequentemente, responder ao problema de pesquisa define-se:

a) Mapear o perfil social, acadêmico e profissional dos Controllers.

b) Analisar a contribuição de vivências e experiências para o desenvolvimento das competências essenciais de um Controller.

c) Debater a relação entre a trajetória dos Controllers e aspectos de sua prática profissional. 


\subsection{JUSTIFICATIVA}

Visto que a Controladoria é um campo de estudos onde muitos aspectos não estão consolidados e, também, diante do reduzido número de pesquisas partindo da prática profissional, este estudo justifica-se por trazer elementos necessários para debater a formação do Controller, desenvolver e aperfeiçoar as competências requeridas pelos empregadores potenciais e as necessidades dos profissionais na sua vida prática.

Em especial, com relação aos profissionais, presume-se que estudar aspectos como trajetória profissional e desenvolvimento de competências é algo relevante, tanto para os já atuantes, quanto para os postulantes a área. Pois, desta maneira, é possível reunir esforços e investir em vivências para desenvolver as competências requeridas e, assim, aumentar o desempenho. Isto, de maneira especial, para aqueles que valorizam o aperfeiçoamento profissional e a aprendizagem continuada.

Ademais, será possível contribuir com as instituições de ensino para o delineamento da formação deste profissional através de: (1) ideias para ajustes nos currículos e métodos de ensino, visando à adequação à realidade do mercado, proporcionando a melhoria dos cursos ofertados; (2) constatação da necessidade de oferta de cursos de especialização e extensão focados em certas áreas de conhecimento; e (3) desenvolvimento de cursos específicos com a finalidade de suprir a necessidade de profissionais mais especializados em determinadas áreas do saber (PIRES; OTT; DAMACENA, 2009). 


\section{REVISÃO DA LITERATURA}

\subsection{COMPETÊNCIAS}

\subsubsection{Conceitos}

No senso comum, a palavra competência é empregada para definir alguém qualificado para realizar uma tarefa. $\mathrm{O}$ oposto, além de indicar a negação de uma capacidade, guarda um sentido pejorativo (FLEURY; FLEURY, 2007). No âmbito organizacional e da gestão de recursos humanos, a conceituação de competência apresenta uma grande variedade de percepções e ainda muitas indefinições, o que dificulta o seu entendimento pelas empresas (RUAS, 2005).

Antes de apresentar esta variedade de percepções, acerca das competências no meio corporativo, vale trazer os níveis e instâncias de compreensão onde este conceito está inserido. Fleury e Fleury (2001) argumentam que o tema competência, em debates acadêmicos e empresariais, pode ser compreendido no nível da pessoa (a competência do indivíduo), das organizações (as core competences) e dos países (sistemas educacionais e formação de competências).

Alinhado, em certa medida, ao entendimento acima exposto, Ruas (2005) dispõe essas dimensões aos níveis institucionais das empresas, da seguinte maneira: (1) No nível organizacional, como competência coletiva, que seria o diferencial de competitividade de determinada empresa; (2) No nível funcional, ou intermediário, também coletiva, associada às competências das áreas das empresas; e (3) No nível individual, dos indivíduos.

A partir desses dois entendimentos, e conforme corroboram os trabalhos de Dutra (2004), Zarifian (2001), Le Boterf (2003), o estudo das instâncias da competência evoluem basicamente do nível individual (dos recursos das pessoas) para o nível coletivo (grupos e instituições). Desta feita, as percepções e, consequentemente, os conceitos de competência estarão nestes níveis, individual e coletivo.

Alinhado ao exposto, Dutra (2004) apresenta o desenvolvimento do conceito de competência em quatro fases, conforme a seguir: Primeira fase, baseada nos estudos de McClelland (1973) e Boyatzis (1982). Focada nas definições de padrões de trabalhos baseados em competências individuais que garantem aos profissionais uma alta performance; Segunda fase, incorpora os conceitos da primeira fase, mas criando escalas de diferenciação por nível de complexidade das tarefas; Terceira fase, que traz o conceito de competência 
organizacional (coletiva), e a ideia de alinhar esta com a competência de cada indivíduo; Quarta fase, a apropriação das pessoas dos conceitos lançados pela terceira fase.

É a partir da perspectiva do indivíduo que historicamente o conceito de competência começa a ser estudado no âmbito das organizações, tendo como marco o artigo de McClelland, Testing for competence rather than intelligence, publicado nos Estados Unidos em 1973 (FLEURY; FLEURY, 2007).

Em linhas gerais, há na atualidade duas correntes distintas de abordagem sobre as competências individuais: (1) a anglo-saxã ou norte-americana, pragmática e atrelada ao conceito de qualificação de um indivíduo que garante um desempenho superior; e (2) a escola francesa, que integra em uma visão ampla fundamentos da sociologia e da economia do trabalho, atrelando competência com o saber colocar em prática (DUTRA, 2004 e RUAS, 2005).

O conceito norte-americano de competência nasceu sob influência do taylorismo, tendo como foco identificar e aperfeiçoar as habilidades e conhecimentos dos profissionais no desempenho de uma determinada função (BRANDÃO, 2009).

Neste sentido, o principal enfoque do trabalho seminal de McClelland (1973) era o questionamento da função dos testes de Inteligência utilizados para a o recrutamento e seleção de pessoas para as empresas. Para o autor, embora esses testes tenham sido validados, as evidências que mediam as habilidades essenciais para um desempenho superior eram fracas. Ademais, ele indicou que as variáveis sociais influenciavam fortemente o sucesso de um profissional. Para Araujo (2011), além destas ideias, o principal ponto deste trabalho foi a diferenciação do conceito de competência das noções de aptidão, habilidade e conhecimento. Nesta perspectiva, aptidão seria um talento natural de alguém, habilidade uma capacidade específica prática e conhecimentos seriam informações necessárias para desempenhar uma função (FLEURY; FLEURY, 2007).

Outro trabalho importante desta corrente é o livro The competent manager, de Boyatzis (1982). De acordo com Cardoso (2006), o cerne desta obra é investigar características que gerentes deveriam possuir para uma performance mais eficaz, levando em consideração demandas da função, o ambiente e as competências do profissional. A novidade, segundo o mesmo, seria a inclusão do contexto onde o profissional está inserido como uma variável importante para comportamentos aceitáveis. Neste entendimento, há uma relação estreita entre competência e as necessidades estabelecidas pelos cargos existentes nas organizações (FLEURY; FLERY, 2007). 
Para Araujo (2011), sob a perspectiva da vertente norte-americana, existem características específicas dos indivíduos que guardam uma relação com um alto padrão de desempenho em determinada tarefa. Isto, ainda segundo o mesmo, pode ser avaliado de acordo com algum parâmetro de desempenho. Ou seja, competência seria um estoque de recursos, dispostos entre conhecimentos, habilidades e atitudes (CHA), que garantem ao indivíduo um desempenho superior no ambiente de trabalho (FLEURY; FLERY, 2007).

Com relação a estes conceitos, Durand (2000) explica que: (1) conhecimentos são as informações necessárias para executar certo trabalho, seria o "Saber o quê" e "Saber o porquê"; (2) habilidades envolvem a técnica e a capacidade do profissional, seria "Saber como"; e (3) atitudes estão relacionadas a identidade e vontade do trabalhador, o "Querer fazer”. Brandão (2009) complementa dizendo que conhecimento é o saber acumulado por uma pessoa ao longo da vida, habilidade é a capacidade de utilizar produtivamente o conhecimento e a atitude seria a predisposição em fazer algo.

Indo além da ideia de estoques de recursos que garantem alto desempenho em uma função ou cargo, Zarifian (2001) e Le Boterf (1994 e 2003) trazem para o debate sobre competências o ideal de agregação de valor e entrega a determinado contexto, independente da função desempenhada (CARDOSO, 2006). Com base neste alicerce surge a corrente europeia, com forte influência de autores franceses, de abordagem de competência.

De acordo com Fleury e Fleury (2001), o debate francês sobre competência surgiu ainda na década de 1970, com o objetivo de alinhar as necessidades das empresas com a capacitação dos trabalhadores, principalmente na indústria. Segundo os autores, os franceses começaram a questionar o conceito de qualificação proposto e sua relação com o processo de formação profissional.

A partir dos anos de 1990, em um ambiente empresarial e de negócios mais instável e suscetível a mudanças, cresceu o interesse das organizações e de pesquisadores pela noção de competência proposta pelos franceses, visto que esta buscava ir de encontro às bases tayloristas, focadas no saber executar bem determinada tarefa. O foco se tornou o saber mobilizar recursos adequadamente em conjunturas de baixa previsibilidade, em situações que fugiam da rotina de trabalho (ARAUJO, 2011).

Neste sentido, o entendimento de Zarifian (2001) sobre competência parte da constatação da transformação do processo produtivo, no qual a automação industrial, e/ou a informática, reposiciona a atividade humana no ambiente de trabalho. A questão, segundo o autor neste novo panorama, gira em torno de uma situação parcialmente inesperada, que foge do desenrolar natural das atividades. Ou, também, de novos problemas impostos pelo 
ambiente. São os chamados "eventos", circunstâncias onde as intervenções humanas são colocadas à prova.

Para, Le Boterf (2003), o que se requer de um profissional é que ele saiba administrar situações profissionais complexas, sendo capaz de estruturar recursos naquele instante, sem recorrer a combinações passadas, criando, inovando e reconstruindo. Conforme o autor, essa capacidade de "saber administrar recursos" deve estar alinhada a seis ações, apresentadas no Quadro 1:

Quadro 1: O saber administrar recursos

\begin{tabular}{|l|l|}
\hline \multicolumn{1}{|c|}{ Ações } & \multicolumn{1}{c|}{ Capacidade } \\
\hline Saber agir com pertinência. & $\begin{array}{l}\text { Capacidade de encarar um imprevisto, saber ir } \\
\text { além do prescrito. }\end{array}$ \\
\hline $\begin{array}{l}\text { Saber mobilizar saberes e conhecimentos } \\
\text { em um contexto profissional. }\end{array}$ & $\begin{array}{l}\text { Capacidade de utilizar conhecimentos e } \\
\text { habilidades (recursos) em um determinado } \\
\text { contexto. }\end{array}$ \\
\hline $\begin{array}{l}\text { Saber integrar ou combinar saberes } \\
\text { múltiplos e heterogêneos. }\end{array}$ & $\begin{array}{l}\text { Capacidade de organizar e empregar elementos } \\
\text { necessários, em uma variedade de recursos. }\end{array}$ \\
\hline Saber transpor. & $\begin{array}{l}\text { Capacidade de aplicar conhecimento e habilidades } \\
\text { em contextos distintos. }\end{array}$ \\
\hline Saber aprender e aprender a aprender. & Capacidade de tirar lições de cada experiência. \\
\hline Saber envolver-se. & $\begin{array}{l}\text { Capacidade de se envolver na execução de uma } \\
\text { atividade, de tomar iniciativas e fazer propostas. }\end{array}$ \\
\hline
\end{tabular}

Fonte: Adaptado de Le Boterf (2003).

Outro ponto importante da definição de competência por Le Boterf (2003) é o reconhecimento, visto que esta só existe socialmente, após o julgamento de outras pessoas, ela precisa ser validada. Ou seja, segundo o autor, um indivíduo tem competência para um determinado trabalho quando atinge os objetivos esperados e alcança o reconhecimento de terceiros.

Em uma perspectiva bem próxima a de Le Boterf (2003), Fleury e Fleury (2007) trazem para o seu conceito de competência o "saber agir consciente" e, também, a questão do reconhecimento. Ademais, eles entendem que a competência é capaz de agregar valor econômico as empresas e valor social ao indivíduo. Os autores esquematizam este conceito conforme a Figura 1. 
Figura 1: Competências como fonte de valor para o individuo e para a organização

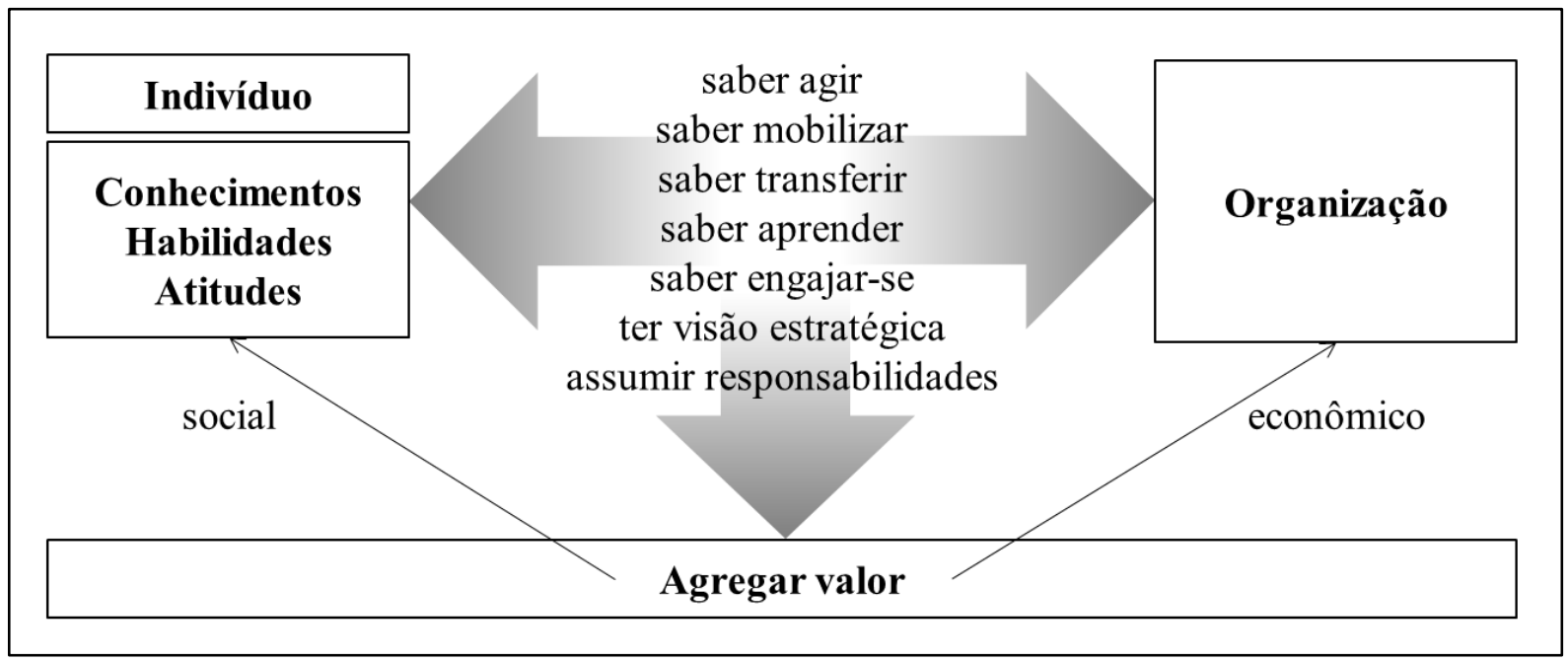

Fonte: Fleury e Fleury (2007).

A proposta de Zarifian (2001) para a definição de competências envolve três dimensões: (1) A da autonomia do indivíduo, onde o mesmo toma iniciativa e assume responsabilidades diante de situações profissionais. (2) A da dinâmica de aprendizagem, que se caracteriza pelas transformações dos conhecimentos adquiridos através das situações práticas. (3) A da capacidade de agir coletivamente, mobilizando redes de atores capazes de compartilhar as implicações de suas ações e, também, de assumir campos de corresponsabilidade. Na Figura 2, Dutra (2004) resume a distinção entre essas duas correntes, enfatiza o foco de cada uma e apresenta autores que já promovem uma interseção entre elas.

Figura 2: Conceitos sobre competência

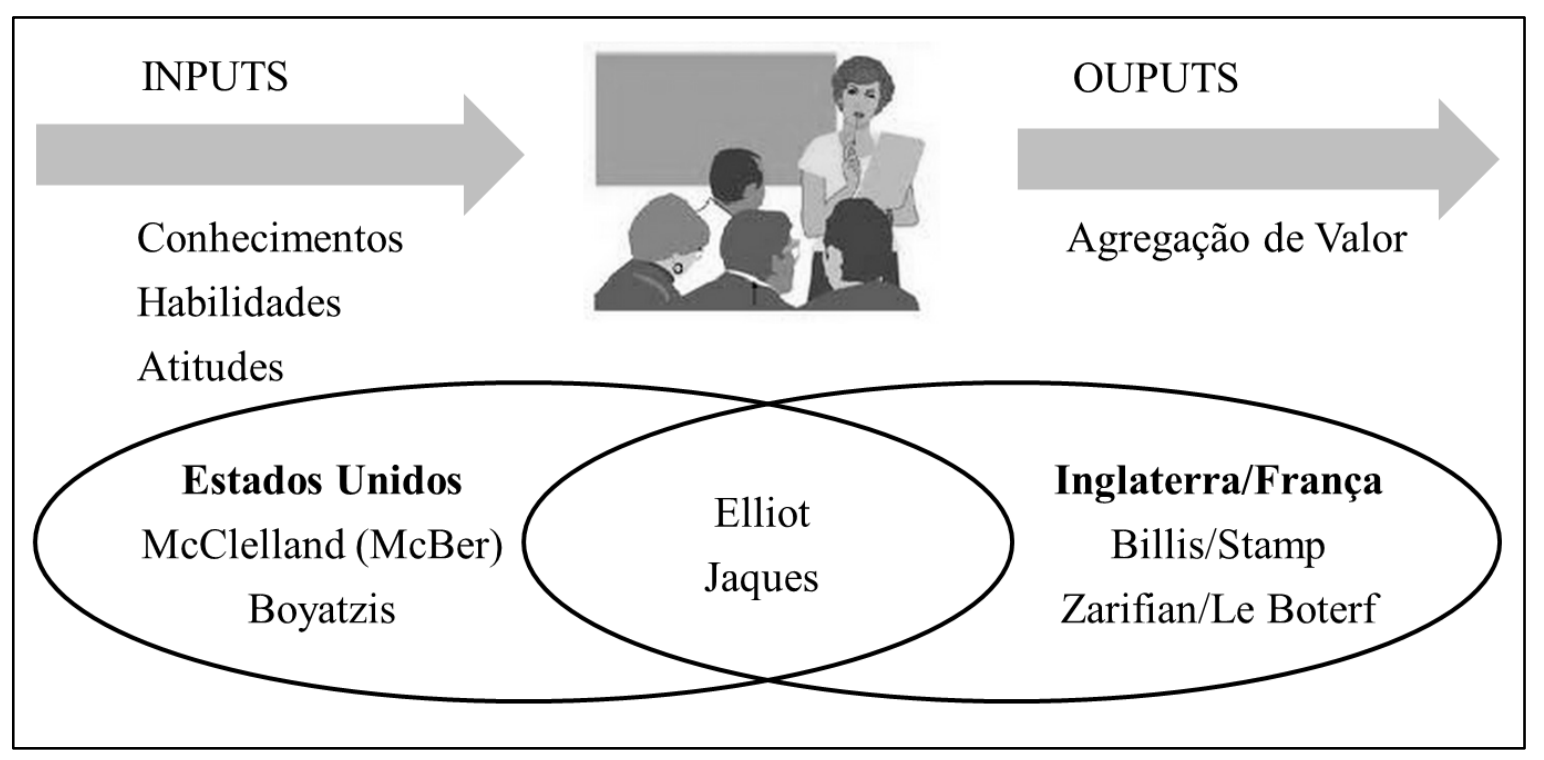

Fonte: Dutra (2004). 
Ao tratar da distinção entre as duas correntes, Ruas (2005) enfatiza a diferença entre qualificação e competência. Para ele, a qualificação está alinhada ao entendimento norteamericano, já a competência com o entendimento francês. A Figura 3 apresenta estes conceitos e distinções

Figura 3: Noções de qualificação e competências e características principais dos respectivos contextos

\section{QUALIFICAÇÃO}

- Relativa estabilidade da atividade econômica

- Concorrência localizada

- Lógica predominante: indústria (padrões)

- Organização do trabalho com base em cargos definidos e tarefas prescritas e programadas

- Foco no processo

- Baixa aprendizagem

\section{COMPETÊNCIA}

- Baixa previsibilidade de negócios e atividades

- Intensificação e ampliação da abrangência da concorrência

- Lógica predominante: serviços (eventos)

- Organização do trabalho com base em metas, responsabilidades e multifuncionalidade

- Foco nos resultados

- Alta aprendizagem

Fonte: Ruas (2005).

Para Araújo (2011), adotar este enfoque de competência relacionado com a entrega e a agregação de valor, e não em função do conceito de cargo, é algo valioso, pois, a partir de um perfil de competências, é possível realizar com mais qualidade a contratação, desenvolvimento, avaliação e remuneração de profissionais.

\subsubsection{Desenvolvimento de Competências}

Conforme Ruas (2005), o conceito de competência direciona um foco especial para o desenvolvimento de capacidades e recursos que podem ser mobilizados por indivíduos em eventos de pouca previsibilidade dentro das organizações. Ou seja, de um lado estão os profissionais, constituídos de recursos próprios, e do outro estão as organizações, com suas capacidades e necessidades. Conciliar esta relação, e agregar valor para as duas partes, é o grande desafio na gestão de pessoas, pois os conhecimentos, habilidades e atitudes dos indivíduos se transformam em competências entregues as empresas (ARAUJO, 2011). 
Dutra (2004) explica que avaliar as pessoas por sua capacidade de agregar valor traz um panorama mais adequado na orientação de seu desenvolvimento. É dentro desta perspectiva que os autores franceses constroem o debate sobre o desenvolvimento de competências individuais, associando à agregação de valor a organização.

No que tange ao desenvolvimento das pessoas com o objetivo de aprimorar sua entrega e ampliar suas responsabilidades, é possível pensar em duas categorias: (1) As ações de desenvolvimento formais, relacionadas com metodologias didáticas e conteúdos programáticos definidos, que seriam os cursos, palestras, seminários etc; e (2) As ações de desenvolvimento informais, ligadas a atuação do trabalhador no ambiente de trabalho, como coordenação ou participação em projetos, estágios, visitas etc. (DUTRA, 2004).

No Quadro 2, Le Boterf (2003) apresenta as formas de aquisição dos saberes necessários para as competências, a função de cada um deles, a principal maneira de aquisição e como estes se manifestam.

Quadro 2: Recursos incorporados ao profissional

\begin{tabular}{|l|l|l|l|}
\hline \multicolumn{1}{|c|}{ Tipo } & \multicolumn{1}{|c|}{ Função } & \multicolumn{1}{c|}{ Modo principal de aquisição } & \multicolumn{1}{c|}{$\begin{array}{c}\text { Modo de } \\
\text { manifestações }\end{array}$} \\
\hline Saberes teóricos & Saber compreender & $\begin{array}{l}\text { Educação formal; Formação } \\
\text { inicial e contínua }\end{array}$ & Declarativo \\
\hline Saberes de meio & $\begin{array}{l}\text { Saber adaptar-se; } \\
\text { Saber agir conforme a } \\
\text { situação }\end{array}$ & $\begin{array}{l}\text { Formação contínua e experiência } \\
\text { profissional }\end{array}$ & Declarativo \\
\hline $\begin{array}{l}\text { Saberes } \\
\text { procedurais }\end{array}$ & Saber como proceder & $\begin{array}{l}\text { Educação formal; Formação } \\
\text { inicial e contínua }\end{array}$ & $\begin{array}{l}\text { Declarativo e } \\
\text { procedural }\end{array}$ \\
\hline $\begin{array}{l}\text { Saber-fazer } \\
\text { operacionais }\end{array}$ & $\begin{array}{l}\text { Saber proceder; Saber } \\
\text { operar }\end{array}$ & Experiência profissional & Procedural \\
\hline $\begin{array}{l}\text { Saber-fazer } \\
\text { experencial }\end{array}$ & $\begin{array}{l}\text { Saber agir em função } \\
\text { de algo }\end{array}$ & Experiência profissional & Procedural \\
\hline $\begin{array}{l}\text { Saber-fazer } \\
\text { sociais ou } \\
\text { relacionais }\end{array}$ & $\begin{array}{l}\text { Saber cooperar; Saber } \\
\text { conduzir-se }\end{array}$ & Experiência social e profissional & Procedural \\
\hline $\begin{array}{l}\text { Saber-fazer } \\
\text { cognitivo }\end{array}$ & $\begin{array}{l}\text { Saber tratar a } \\
\text { informação; Saber } \\
\text { raciocinar }\end{array}$ & $\begin{array}{l}\text { Educação formal; Formação } \\
\text { inicial e contínua; Experiência } \\
\text { social e profissional analisada }\end{array}$ & Procedural \\
\hline
\end{tabular}

Fonte: Le Boterf (2003)

Para Le Boterf (2003), quanto às formas de aquisição dos saberes: (1) a educação formal seria a educação escolar básica de um indivíduo; (2) a formação inicial e continuada 
referem-se aos cursos profissionalizantes, graduações e pós-graduações; (3) a experiência profissional envolve a vida prática do trabalhador e; (4) a experiência social as vivências fora do ambiente de trabalho e escolar.

Com relação às formas de manifestação: (1) o modo declarativo é a expressão do conhecimento, ainda está separada do uso, serve para descrever; e (2) o modo procedural onde os saberes se manifestam na atividade prática, serve para prescrever (LE BOTERF, 2003).

Fleury e Fleury (2007) compilam essas informações de uma forma mais sintética, conforme pode ser visto no Quadro 3. Segundo eles, a competência situa-se em uma encruzilhada formada pela pessoa e sua biografia, a formação educacional e sua experiência profissional.

Quadro 3: Processo de desenvolvimento de competências

\begin{tabular}{|c|c|c|}
\hline Tipo & Função & Como Desenvolver \\
\hline Conhecimento teórico. & Entendimento, interpretação. & $\begin{array}{l}\text { Educação formal e } \\
\text { continuada. }\end{array}$ \\
\hline $\begin{array}{c}\text { Conhecimento sobre os } \\
\text { procedimentos. }\end{array}$ & Saber como proceder. & $\begin{array}{c}\text { Educação formal e } \\
\text { experiência profissional. }\end{array}$ \\
\hline Conhecimento empírico. & Saber como fazer. & Experiência profissional. \\
\hline Conhecimento social. & Saber como comportar-se. & $\begin{array}{c}\text { Experiência social e } \\
\text { profissional }\end{array}$ \\
\hline Conhecimento cognitivo. & $\begin{array}{c}\text { Saber como lidar com a } \\
\text { informação, saber como } \\
\text { aprender. }\end{array}$ & $\begin{array}{l}\text { Educação formal e } \\
\text { continuada, e experiência } \\
\text { social e profissional. }\end{array}$ \\
\hline
\end{tabular}

Fonte: Fleury e Fleury (2007)

Ainda com relação a estas formas de desenvolvimento de saberes, Perrenoud (1999) comenta que as experiências profissionais são fontes muito ricas de conhecimentos. Na sua visão, a rotina de trabalho consegue ensinar e construir competência em uma velocidade maior. Alinhado a esta ideia, Dutra (2004) explica que a trajetória profissional direciona naturalmente o desenvolvimento de um indivíduo.

\subsubsection{Estudos Anteriores}

Com relação aos estudos recentes sobre o desenvolvimento de competências, o "Journal of Management Development" publicou no ano de 2008 um volume especial chamado "Competencies in the 21st century", com editorial de Boyatzis, um dos precursores da corrente norte americana. Segundo Boyatzis (2008), esta edição especial tem o objetivo de 
atualizar o entendimento de competência, oferecendo quatro artigos que mostram a relação entre competências emocionais, sociais e cognitivas em várias ocupações.

Já no editorial, Boyatzis (2008) busca esta atualização definindo competência como uma capacidade ou habilidade, um conjunto de comportamentos organizados em torno de uma intenção. Ademais, destacam-se os artigos a seguir.

O artigo de Boyatzis e Saatcioglu (2008) apresenta uma atualização da visão de 20 anos de tentativas para desenvolvimento de competências, estudando 14 pesquisas longitudinais de um programa de MBA. Os achados deste indicam que a competência emocional, social e de inteligência cognitiva predizem eficácia em gestão e liderança, e podem ser desenvolvidas através de programas de pós-graduação.

Através de um estudo empírico, Leonard (2008) revela que o estabelecimento de metas de aprendizagem é particularmente importante para o desenvolvimento de competências, pois estas foram mais desenvolvidas em indivíduos que fixaram esses objetivos. Para chegar nesta conclusão, o autor fez um estudo longitudinal, que variou de nove meses a quatro anos e meio, com alunos de um programa de MBA. Esta pesquisa é parte de estudo longitudinal de 50 anos, sobre o desenvolvimento de competências e de experiências de carreiras, de estudantes de MBA, realizado no Case Western Reserve University.

O objetivo da pesquisa de Wheeler (2008) foi analisar as interações entre indivíduos e o ambiente social, e como esses indivíduos se engajam em auto aprendizagem. O número de esferas de vida, relacionamentos e atividades impactam positivamente na demonstração das competências. Aqueles participantes para quem a esfera da vida "empresa" é fundamental para o alcance dos objetivos da aprendizagem, manifestaram com mais clareza as competências-alvo.

Estudos ainda mais recentes também abordam a temática. Pinnington (2011) teve como objetivo analisar advogados no início de sua trajetória profissional, procurando compreender o desenvolvimento de competências e a evolução de suas carreiras. O estudo se deu através de entrevistas com advogados de nível júnior de um grande escritório de advocacia. $\mathrm{O}$ artigo considera a competência profissional e progressão na carreira a partir de uma perspectiva ontológica, vendo-os como "modos de ser". Para análise das entrevistas foi utilizada uma abordagem interpretativa onde a competência de um indivíduo pode ser relacionada a uma auto-compreensão particular. O resultados indicaram que a auto-percepção dos advogados é fortemente influenciada pela fase da sua carreira e, também, por sua posição na organização. Em contrapartida, sua compreensão sobre o trabalho revela mais questões 
individuais e particulares das atividades de trabalho, formas distintas de reconhecimento e desenvolvimento de competências técnicas e profissionais.

O estudo de Van Buuren e Edelenbos (2013) descrevem os resultados de um estudo de caso comparativo, em organizações públicas holandesas, de dois métodos de desenvolvimento de competências. Uma metodologia é vista com uma abordagem mais orientada para a formação teórica (programa LWT), enquanto que a outra tem um viés de treinamento orientado pela prática (programa $\mathrm{PwC}$ ). Ambos os casos foram avaliados por meio de uma mistura de métodos de investigação, tais como observação participante, entrevista e survey. Os resultados indicam que a abordagem orientada para a prática, programa $\mathrm{PwC}$, que faz uso de técnicas de coaching, parece estar melhor equipada para desenvolver competências específicas de uma situação do que a abordagem orientada por teoria, como testemunhado na LWT. No entanto, o último é mais adequado para comunicar novos conhecimentos, o que tem muito mais aplicação. Enquanto o primeiro método é muito mais eficaz no livre ajuste do ambiente de aprendizagem, o último é muito mais eficiente em comunicação de novos conhecimentos num curto período de tempo para muitos empregados simultaneamente. $\mathrm{O}$ primeiro é mais difícil de organizar e consolidar, ao passo que o último é muito mais difícil de se relacionar com as práticas organizacionais reais.

Velasco (2014) propõe um modelo de desenvolvimento de competências exigidas dos diplomados no trabalho. Para isso, ele precisou identificar as principais competências necessárias para os formados, em que medida, as instituições de ensino superior da Espanha forneceram uma base sólida para o desenvolvimento destas. O artigo utiliza o conjunto de dados fornecido pelo projeto chamado REFLEX (abreviação de Investigação sobre o Emprego e flexibilidade profissional), que teve como população-alvo alunos que se formaram no ano letivo de 1999-2000, em treze países europeus. O estudo de Velasco incidirá sobre o caso espanhol, com dados sobre quase 4.000 jovens diplomados. A pesquisa, realizada em 2005, continha perguntas sobre o ensino universitário, a transição do ensino superior para o primeiro emprego e a situação do mercado de trabalho 5 anos depois de terem se formado. $\mathrm{O}$ autor conclui que as competências mais exigidas para os graduados são: (a) a mobilização de suas próprias capacidades (utilizando tempo de forma eficiente, bom desempenho sob pressão); (b) a mobilização de outros profissionais (trabalhando de maneira produtiva com os outros, coordenando as atividades, explicando com clareza para os outros); e (c) ter bom conhecimento especializado (domínio do próprio campo, capacidade de adquirir novos conhecimentos rapidamente). Por fim, o trabalho indica que as IES espanholas conseguem desenvolver, em certa medida, essas competências. 


\subsection{CONTROLADORIA}

\subsubsection{Conceitos}

O profissional que desenvolve as atividades relacionadas à Controladoria é conhecido no ambiente acadêmico e profissional brasileiro como controller. Dependendo da época e do país, esta função tem diferentes nomenclaturas e atribuições (FERRARI et al., 2013). A história da Controladoria no Brasil e, consequentemente, deste profissional está ligada ao desenvolvimento e expansão desta atividade em empresas norte-americanas.

A Controladoria, na iniciativa privada, é voltada para atender necessidades das áreas de finanças, surgiu nos Estados Unidos na segunda metade do século XIX (JACKSON, 1949 apud LUNKES et al, 2012). Segundo Horváth (2006, apud Lunkes et al., 2012), a General Electric Company foi a primeira empresa norte-americana a formalizar a função de controller, em 1882. No início do século XX, conforme Beuren (2002), ela já fazia parte da realidade das grandes corporações norte-americanas, atuando no controle dos negócios das empresas, fossem subsidiárias ou filiais.

Deste ponto em diante, a Controladoria ganhou importância dentro do ambiente coorporativo, fazendo surgir órgãos como Controller's Institute of América que elaboraram em 1946 uma primeira versão institucional das funções dos controllers (LUNKES et al, 2009). Atualmente, vale ressaltar como órgão de representação o International Federation of Accounting (IFAC). Em sua definição, ele destaca a importância do controller para gerar informações qualificadas nas funções de planejamento, avaliação e controle de suas atividades e, também, para assegurar o uso adequado dos recursos. (CALIJURI, 2004).

No Brasil, não há um marco exato para o início da Controladoria e de suas funções (LUNKES; SCHNORRENBERGER, 2009). Porém, devido ao grande ingresso de investimentos de empresas norte-americanas na segunda metade da década de 50, acredita-se que esta função tenha surgido no Brasil neste período, cargos estes ocupados inicialmente por estrangeiros. Os primeiros anúncios no Brasil para este posto datam da década de 1960, nessa época com uma baixa quantidade de ofertas de trabalho. $\mathrm{O}$ aumento da demanda por este profissional, e a sua consolidação no mercado de trabalho ocorreu, a partir da década de 80 (SIQUEIRA; SOLTELINHO, 2001). Lunkes et al. (2009) explicam ainda que a Controladoria no cenário nacional, e consequentemente a atuação do Controller, devem ser analisados em dois momentos distintos no país: antes e depois das pesquisas sobre o GECON, promovidas pelo Professor Armando Catelli no final dos anos 1970. 
Apesar de ter surgido ainda no século XIX, e as primeiras pesquisas na área datarem da primeira metade do século XX, a Controladoria, conforme Ferrari et al. (2013), ainda precisa construir um conjunto mais claro de conceituações acerca de si. Anderson (1944), em um dos primeiros artigos a debater o assunto, já retratava esta dificuldade. Para Beuren (2002), por exemplo, as atuais abordagens sobre o tema, ao invés de tentar esclarecer seu verdadeiro significado, focam mais diretamente nas capacidades e atribuições para o exercício da função.

Segundo Anderson (1944), a Controladoria surgiu com a responsabilidade de manter os registros da empresa, elaborar relatórios e, principalmente, interpretar as informações contidas neles. Seria uma evolução natural da função contábil, uma ampliação do seu escopo de atuação. Neste sentido, Machado et al. (2010) explicam que esta é parte da contabilidade e amplia seu propósito agregando atividades de gestão de informação, controle interno, planejamento tributário, elaboração do orçamento e medidas operacionais, sendo assim decisiva para a gestão estratégica das entidades.

Desta feita, conforme explicam Almeida, Parisi e Pereira (2001), para uma correta compreensão do conceito de Controladoria é preciso dividi-la em duas vertentes: (1) Como unidade administrativa, responsável pela coordenação e disseminação da Tecnologia de Gestão; e (2) Como ramo do conhecimento, responsável pela base conceitual.

Como unidade administrativa, Mosimann e Fisch (1999) argumentam que a ela tem como finalidade garantir informações oportunas para o processo decisório, colaborar com os gerentes na gestão de suas áreas e assegurar a eficácia operacional. Já conforme Almeida, Parisi e Pereira (2001), esta seria responsável por direcionar os esforços da entidade para a otimização de seus resultados. Por fim, para Borinelli (2006), ela é a responsável pelo controle do processo de gestão e do fornecimento de informações para a tomada de decisão de agentes internos e externos.

Como ramo de conhecimento, conforme Mosimann e Fisch (1999), alicerçada nos princípios e técnicas da Administração, Economia, Psicologia, Estatística e, especialmente, a Contabilidade, a Controladoria é responsável pela gestão econômica das empresas, com foco na eficácia do negócio. Segundo Almeida, Parisi e Pereira (2001), ela está alicerçada na Teoria da Contabilidade e numa visão multidisciplinar. Já Borinelli (2006) argumenta que é um conjunto de conhecimentos aglutinados em bases conceituais de ordem operacional, econômica, financeira e patrimonial.

Os primeiros profissionais a ocuparem o cargo de Controller vieram das áreas de finanças e, principalmente, contabilidade, visto a forte relação já apresentada da função com 
Ciência Contábil. Hoje, com a expansão do seu escopo de atuação, profissionais da área de engenharia, administração e análise de sistemas também ocupam este cargo (ORO et al., 2009). Ou seja, cada vez mais deixa de ser uma função primordialmente contábil para trabalhar com atividades estratégicas das organizações (GOMES; SOUZA; LUNKES, 2014). No entanto, conforme estudo de Ferrari et al. (2013), somente o Conselho Federal de Contabilidade prevê a função de controller como prerrogativa da profissão contábil no Brasil.

Com relação ao perfil ideal do controller, Machado et al. (2010) explicam que é preciso um conjunto de competências de natureza técnica e/ou pessoal. Quanto às competências de natureza técnica, Mosimann e Fisch (1999) defendem que este profissional deve ter uma visão generalista do negócio, exigindo conhecimentos de todas as áreas da entidade. Já as competências de natureza pessoal estão relacionadas com habilidades intelectuais e pessoais, tais como raciocínio analítico, flexibilidade, comportamento social, capacidade de inspirar confiança etc. (KÜPPER, 2005 apud MACHADO et al, 2010).

\subsubsection{Funções da Controladoria}

A Estrutura Conceitual Básica proposta por Borinelli (2006) aborda bem as duas direções apresentadas anteriormente, ramo de conhecimento e unidade administrativa. No entanto, ele vai além desta visão incluindo mais uma perspectiva, a das funções da Controladoria.

De início, conforme Anderson (1944), as funções da Controladoria estavam atreladas à proteção dos ativos da empresa, ao cumprimento de relatórios legais e exigências de manutenção de registros e assistência à gestão na formulação de políticas e operações de controle.

Mais recentemente, conforme o Quadro 4, Almeida, Parisi e Pereira (2001), entendem que as funções têm em seu escopo as seguintes finalidades: 
Quadro 4: Funções desempenhadas

\begin{tabular}{|l|l|}
\hline \multicolumn{1}{|c|}{ Funções Desempenhadas } & \multicolumn{1}{|c|}{ Atividades } \\
\hline Subsidiar o processo de gestão & $\begin{array}{l}\text { Envolve ajudar a adequação do processo de gestão à } \\
\text { realidade da empresa ante seu meio ambiente. }\end{array}$ \\
\hline Apoiar a avaliação de desempenho & $\begin{array}{l}\text { Elaborando análise de desempenho: Econômico das } \\
\text { áreas; Dos gestores; Econômico da empresa e; Própria } \\
\text { área. }\end{array}$ \\
\hline Apoiar a avaliação de resultado & $\begin{array}{l}\text { Elaborando análise de resultado econômico dos produtos } \\
\text { e serviços; Monitorando e orientando o processo de } \\
\text { estabelecer padrões; Avaliando os resultados dos seus } \\
\text { serviços. }\end{array}$ \\
\hline Gerir os sistemas de informações & $\begin{array}{l}\text { Definição da base de dados; Elaboração dos modelos de } \\
\text { gestão de acordo com as características de cada área e; } \\
\text { Padronizando e harmonizando o conjunto de } \\
\text { informações econômicas (modelo de informação). }\end{array}$ \\
\hline Atender aos agentes do mercado & $\begin{array}{l}\text { Analisando impacto da legislação no resultado e; } \\
\text { Atendendo os diversos agentes do mercado. }\end{array}$ \\
\hline
\end{tabular}

Fonte: Almeida, Parisi e Pereira (2001).

Lunkes e Schnorrenberger (2009) compilam em seu estudo as funções básicas da Controladoria em três perspectivas de gestão: operacional, econômica e estratégica. No Quadro 6 são relatadas as funções dentro de cada perspectiva.

Quadro 5: Perspectivas e funções básicas da Controladoria

\begin{tabular}{|c|c|}
\hline Perspectivas & Funções Básicas \\
\hline Gestão Operacional & $\begin{array}{l}\text { - } \text { Planejamento (Operacional) } \\
\text { - } \quad \text { Elaboração de relatórios e interpretação } \\
\text { - Avaliação e deliberação } \\
\text { - Administração de impostos } \\
\text { - Elaboração de relatórios a órgãos reguladores e públicos } \\
\text { - } \text { Proteção do patrimônio } \\
\text { - Avaliações da economia política }\end{array}$ \\
\hline Gestão Econômica & $\begin{array}{ll}\text { - } & \text { Subsidiar o processo de gestão } \\
\text { - } & \text { Apoiar a avaliação de desempenho } \\
\text { - } & \text { Apoiar a avaliação de resultado } \\
\text { - } & \text { Gerir o sistema de informações } \\
\text { - } & \text { Atender aos agentes de mercado } \\
\end{array}$ \\
\hline Gestão Estratégica & $\begin{array}{ll}\text { - } & \text { Planejamento } \\
\text { - } & \text { Sistema de informações } \\
\text { - } & \text { Controle } \\
\text { - } & \text { Gestão de pessoas } \\
\text { - } & \text { Organizacional } \\
\end{array}$ \\
\hline
\end{tabular}

Fonte: Ferrari et al. (2013) 
De forma mais direta, Borinelli (2006) definiu em sua Estrutura Conceitual Básica as funções da Controladoria e as atividades a elas relacionadas, conforme o Quadro 5:

Quadro 6: Funções da Estrutura Conceitual Básica da Controladoria

\begin{tabular}{|c|c|}
\hline Funções & Atividades \\
\hline Função Contábil & $\begin{array}{l}\text { Relacionadas ao desenvolvimento da Contabilidade } \\
\text { Societária e/ou Financeira, tais quais: Gerenciar as } \\
\text { atividades de contabilidade, manter os registros } \\
\text { contábeis, elaborar as demonstrações financeiras, atender } \\
\text { aos stakeholders, proceder à análise interpretativa das } \\
\text { demonstrações contábeis e desenvolver políticas e } \\
\text { procedimentos contábeis e de controle. }\end{array}$ \\
\hline Função Gerencial-Estratégica & $\begin{array}{l}\text { Relacionadas com o fornecimento de informações de } \\
\text { natureza contábil, patrimonial, econômica, financeira e } \\
\text { não-financeira, úteis ao processo de gestão e a tomada de } \\
\text { decisões gerenciais e estratégicas. }\end{array}$ \\
\hline Função de Custos & $\begin{array}{l}\text { Compreende o registro, mensuração, controle, analise e } \\
\text { avaliação dos custos da organização, incluindo análises } \\
\text { gerenciais e estratégicas referentes à viabilidade de } \\
\text { lançamentos de produtos e serviços, resultados de } \\
\text { produtos e serviços, de linhas de negócios e de clientes. }\end{array}$ \\
\hline Função Tributária & $\begin{array}{l}\text { Relativas à Contabilidade Tributária (ou Fiscal): Atender } \\
\text { às obrigações legais, fiscais e acessórias previstas em leis } \\
\text { e normas tributárias. Isto significa registrar, apurar e } \\
\text { controlar impostos, tributos e contribuições, bem como } \\
\text { elaborar o Planejamento Tributário da organização. }\end{array}$ \\
\hline $\begin{array}{l}\text { Função de Proteção e Controle dos } \\
\text { Ativos }\end{array}$ & $\begin{array}{l}\text { Referentes à proteção aos ativos. Por exemplo, } \\
\text { selecionar, analisar e contratar opções de seguros, além } \\
\text { de controlá-los. Envolve ainda as atividades de registrar } \\
\text { e controlar todos os bens da organização. }\end{array}$ \\
\hline Função de Controle Interno & $\begin{array}{l}\text { Compreende o estabelecimento e monitoramento do } \\
\text { sistema de controles internos, destinado a proteger o } \\
\text { patrimônio organizacional e salvaguardar os interesses } \\
\text { da entidade. }\end{array}$ \\
\hline Função de Controle de Riscos & $\begin{array}{l}\text { Relacionadas com a identificação, mensuração, análise, } \\
\text { avaliação, divulgação e controle dos diversos riscos } \\
\text { envolvidos no negócio, bem como seus possíveis efeitos. }\end{array}$ \\
\hline Função de Gestão da Informação & $\begin{array}{l}\text { Relativas a conceber modelos de informações e a } \\
\text { gerenciar as informações contábeis, patrimoniais, de } \\
\text { custos, gerenciais e estratégicas. }\end{array}$ \\
\hline
\end{tabular}

Fonte: Borinelli (2006).

Em um estudo realizado com o objetivo de identificar as funções básicas da Controladoria, com base na literatura de Brasil, Estados Unidos e Alemanha, Lunkes et al. 
(2009) concluem que estas envolvem o Planejamento, o Controle, o Sistema de Informações, a Gestão de Pessoal e Organizacional.

Weber (2011) desenvolveu um modelo teórico, com base na teoria organizacional, a fim de explicar a matriz de atividades de um controller, bem como suas variações. O estudo identifica quatro níveis de tarefas, são eles: Tarefa básica (apresentar a situação econômica da empresa); Atividades que estendem a tarefa básica (informação qualificada para a gestão); Desenvolvimento relacionado com os processos de planejamento (assumir a responsabilidade de monitorar a geração de planos e coordenar os seus conteúdos); e Desenvolvimento em relação à avaliação das informações (fornecimento de informações proativamente). A Figura 5 ilustra o modelo proposto, os níveis de tarefas e suas relações:

Figura 4: Visão geral de modelo de tarefas da Controladoria

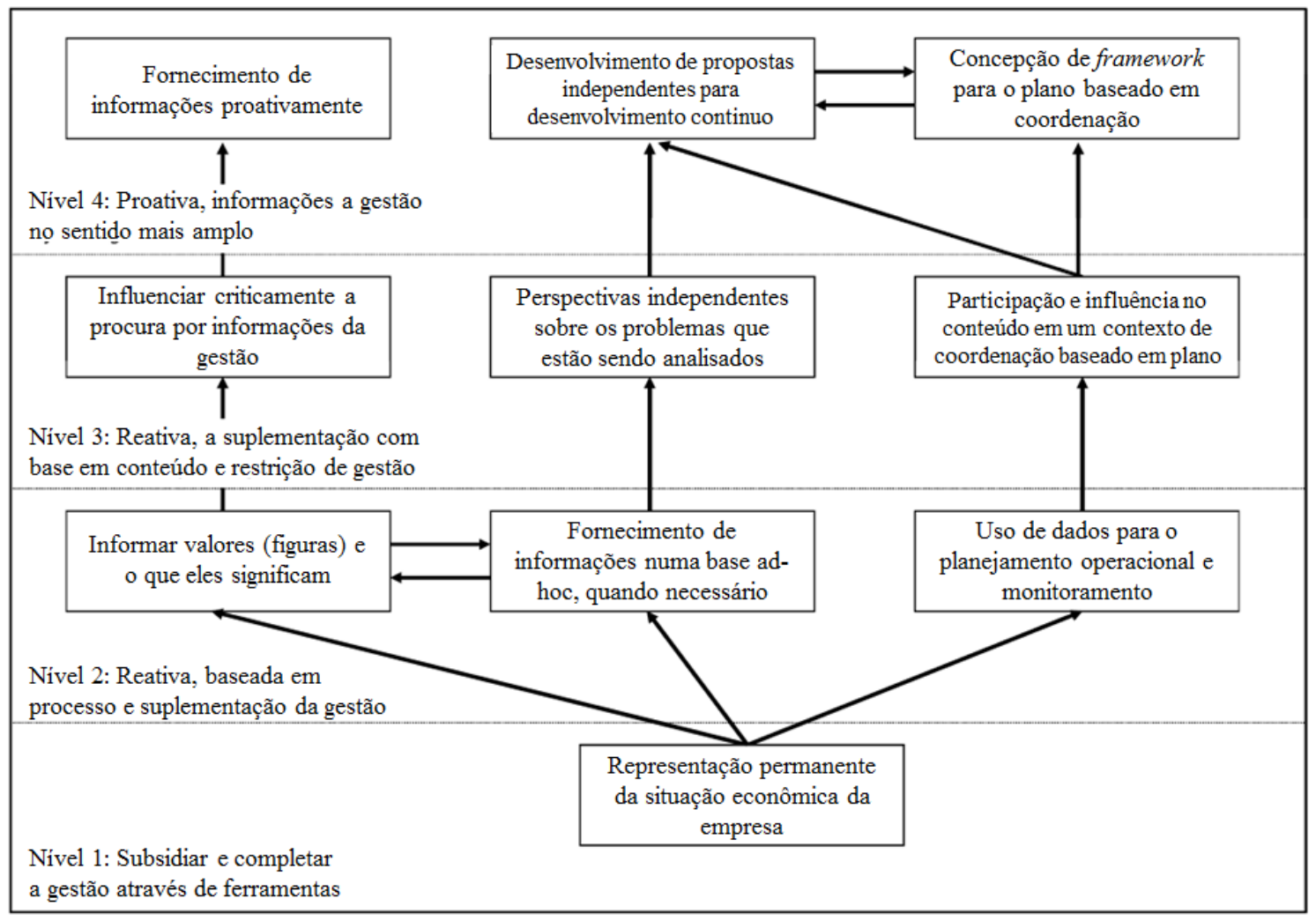

Fonte: Webber (2011).

Por fim, cabe ressaltar o papel da Controladoria para a governança corporativa, como responsável pelos controles internos das entidades e, consequentemente, para a diminuição e mediação dos conflitos entre principal (proprietários) e agentes (gestores) da Teoria da Agência. Isso se dá na medida em que se espera um acompanhamento estreito dos controles organizacionais, assegurando ao principal que os recursos necessários para a operação da empresa estejam sendo consumidos de forma coerente (NASCIMENTO; BIANCHI, 2005). 


\subsubsection{Estudos Anteriores}

Quanto aos estudos relacionados com as funções e competências requeridas, Calijuri (2004) buscou compreender, através de pesquisa junto aos controllers associados da ANEFAC (Associação Nacional dos Executivos de Finanças) e, também em anúncios divulgados na internet para este profissional, aspectos relativos ao exercício do cargo. O estudo teve como enfoque principal as funções desempenhadas, as habilidades requeridas e a formação acadêmica. Os resultados apontaram que as funções mais citadas pelos controllers são gestão de custos, coordenação de fechamentos contábeis mensais e elaboração de relatórios gerenciais, e as mais exigidas em anúncios são gerenciar a área contábil e fiscal, elaboração de relatórios gerenciais, e fechamento contábil em US GAAP. Além disso, este profissional deve ser preferencialmente formado em ciências contábeis e possuir habilidade de liderança, proatividade e facilidade no relacionamento interpessoal.

Com relação à formação profissional, Machado e Casa Nova (2007) verificaram se os conhecimentos adquiridos pelos estudantes no curso de graduação em ciências contábeis atendem aos requisitos do mercado de trabalho do profissional contábil. Compôs a amostra da pesquisa 120 formandos de quatro Instituições de Ensino Superior (IES) da cidade de São

Paulo e 31 profissionais com cargo de chefia de grandes empresas. Após aplicação de questionário, foram comparadas as respostas dos dois perfis, sendo possível identificar em quais áreas de conhecimento esses requisitos foram atendidos e em quais havia discrepâncias. $\mathrm{O}$ estudo demonstrou diferentes percepções de perfis dos conhecimentos entre as instituições de ensino e, também, do que se é exigido pelo mercado de trabalho.

Zoni e Kenneth (2007), através de questionário enviado para 17 empresas italianas, buscaram compreender o envolvimento dos Controllers com o processo de gestão, os motivos para uma maior ou menor participação deste e se o envolvimento tem uma associação significativa com o desempenho. Os resultados demonstraram que a maioria dos Controllers são pouco envolvidos com os processos de decisão da gestão. Além disso, o envolvimento dos Controllers nas decisões estratégicas e/ou operacionais está positivamente relacionado com a intensidade de capital, interdependência operacional, competência dos gerentes de linha financeira, formalização dos processos de planejamento e orçamentos. No geral, a maior participação do Controller pode ser associada positivamente com o desempenho da empresa. Este estudo foi replicado no Brasil por Vargas e Beuren (2012), chegando a resultados semelhantes. 
Cardoso et al. (2010), identificaram as competências requeridas ao Controller e avaliaram se existem competências a serem priorizadas. O estudo está baseado em 18 competências coletadas em 27 artigos sobre as habilidades do contador e do Controller, que foram submetidos, através de questionário, a 198 profissionais de contabilidade gerencial ou controladoria. Após aplicação do instrumento de coleta, chegou-se a 12 variáveis organizadas em 03 fatores: competências técnicas (Contabilidade e finanças, legal, ferramentas de controle, planejamento e capacidade analítica), competências comportamentais (Autocontrole, ouvir eficazmente, trabalho em equipe, gestão da informação e relacionamento externo) e competências de postura (Empreendedora e estratégica). Segundo os autores, esses fatores podem dar respostas ao questionamento sobre quais são as competências requeridas aos contadores gerenciais. Ademais, o estudo ressalta que as capacidades de empreender e de visão estratégica foram colocadas em um fator segregado em relação as demais competências, o que pode sugerir a grande diferença percebida pelos respondentes entre o Controller e as demais especialidades profissionais.

Machado et al. (2010) tiveram como objetivo identificar, através de questionário encaminhado por email, as competências do Controller nas 100 maiores empresas do Estado de Santa Catarina, segundo a Revista Amanhã de 2007. O estudo segregou as competências em pessoais e profissionais. As competências pessoais mais evidentes no estudo são a ética, flexibilidade para mudanças, honestidade e integridade, iniciativa e liderança. As competências profissionais mais importantes, segundo este estudo seriam visão estratégica e de processos, raciocínio lógico, planejamento e organização.

Maciel e Lima (2011), através de entrevistas com profissionais e pesquisadores da área de Controladoria, identificaram o perfil, no que tange conhecimentos, habilidades e atitudes, ideal do Controller no mercado de trabalho. O trabalho traz em seu corpo trechos das entrevistas com estes profissionais e pesquisadores. O estudo conclui que o perfil deve agregar conhecimento de capital humano, capacidade de gerenciar pessoas, domínio de procedimentos de comunicação, espírito de liderança e domínio de línguas.

Ferrari et al. (2013) identificaram, com base nos anúncios do Painel Executivo da Revista Exame (anos de 2005 até 2012), as funções e competências dos Controllers solicitadas no processo de recrutamento e seleção de empresas brasileiras. As funções mais solicitadas foram o gerenciamento da contabilidade, orçamento e controle fiscal/tributário. As competências mais exigidas foram visão global do mercado, dinamismo e liderança. A pesquisa concluiu que o mercado demanda Controllers com capacidade de gerenciamento das 
informações organizacionais, com sólidos conhecimentos técnicos e com habilidade nas relações interpessoais.

Araújo, Callado e Cavalcanti (2014) identificaram as competências desenvolvidas em cursos de pós-graduação lato sensu em Controladoria, relacionadas com o perfil visto na literatura para um Controller. O universo da pesquisa foi composto por alunos de IES da cidade de João Pessoa-PB. Os dados foram coletados através de questionário. Dentre as competências listadas, destacam-se: as habilidades específicas do Controller; elaboração e interpretação de relatórios gerenciais; procedimentos de auditoria; mensuração dos riscos organizacionais; sistemas de informação contábil; consultoria e procedimentos de controle interno. A atribuição "elaboração de orçamento" não teve como ser confirmada entre as desenvolvidas no curso.

Dal Vasco, Daniel e Tarifa (2014) apresentaram as funções e o papel dos Controllers nas cooperativas agropecuárias do Estado do Paraná. O estudo se deu através de questionário aplicado aos Controllers destas cooperativas. Com relação às funções citadas, custos, planejamento e controle orçamentário, elaboração de relatórios gerenciais e fechamentos contábeis foram as mais frequentes. As habilidades e competências mais recorrentes nas respostas foram liderança, iniciativa e flexibilidade. A ética foi citada como atitude imprescindível para a tarefa.

Gomes, Souza e Lunkes (2014) identificaram o perfil exigido pelas empresas brasileiras para a função de Controller, através de anúncios de emprego publicados em cinco sítios eletrônicos de recrutamento e seleção (Hays Brasil, Case Consulting, Catho, Michael Page e Manager). Trabalho semelhante foi realizado anteriormente por Oro et al. (2009) e Souza e Borinelli (2009). O estudo verificou que o mercado tem buscado, preferencialmente, Controllers formados em Ciências Contábeis, com conhecimentos em tecnologia da informação (Excel e sistemas integrados, principalmente) e em contabilidade internacional. Ademais, apesar de nem sempre serem demandadas as funções de planejamento e controle, o mercado exige que este profissional participe da gestão da empresa, com liderança, proatividade e capacidade analítica.

Em resumo, os trabalhos listados demonstram que algumas funções e habilidades aparecem com mais frequência, tais como fechamento contábil, informações gerenciais, planejamento, orçamento, liderança e proatividade. Porém, não existe um rol definitivo destas, isso depende da época, do ambiente e das necessidades das empresas. Ademais, apesar da visão generalista exigida pelo cargo, ainda se busca preferencialmente contadores para desempenhá-lo. 


\section{ASPECTOS METODOLÓGICOS}

\subsection{TIPOLOGIA DA PESQUISA}

A pesquisa, quanto aos objetivos, se caracteriza como descritiva, pois tem como meta descrever a realidade de um universo (RAUPP; BEUREN, 2003). Para Gil (2008), uma de suas principais características é utilizar métodos padronizados de coletas de dados.

Quanto aos procedimentos, este estudo utiliza levantamento ou survey. Conforme Gil (2008), este tipo de método se caracteriza pela consulta direta aos integrantes do universo que se deseja estudar. Ademais, levanta informações que conseguem mapear a realidade do universo estudado (RAUPP; BEUREN, 2003).

Quanto à abordagem do problema, se caracteriza como qualitativa. Segundo Raupp e Beuren (2003) é muito comum a utilização de pesquisa quantitativa em estudos do tipo levantamento ou survey. Porém, o tipo de enfoque deste estudo diferencia-se desta classificação por tentar analisar a interação entre as variáveis e procurar compreender processos dinâmicos vividos por este grupo de profissionais (RAUPP; BEUREN, 2003).

\subsection{UNIVERSO E AMOSTRA}

Conforme explica Miranda (2010), diferente de países como os Estados Unidos e o Reino Unido, não existe uma certificação para contadores gerenciais no Brasil. Isto, naturalmente, dificulta a construção de uma base de dados destes profissionais. De maneira idêntica, isto ocorre com os Controllers, visto que também não há uma certificação específica para este profissional. A entidade que ainda consegue manter uma relação destes profissionais é a Associação Nacional dos Executivos de Finanças (ANEFAC), uma das bases do trabalho de Calijuri (2004), mas não se limitam somente aos Controllers.

Nesta pesquisa, optou-se por seguir uma das estratégias de Miranda (2010), construir esta base de profissionais de controladoria através de usuários da rede social LinkedIn. Uma rede social é um sistema de organização de pessoas ou organizações, conectadas por vários tipos de relação, que partilham conhecimentos, crenças ou prestígio (MIRANDA, 2010). Segundo dados do sítio LinkedIn (www.linkedin.com), esta rede social possui mais de 300 milhões de usuários, em mais de 200 países e territórios em todo o mundo, sendo mais de 20 milhões de usuários no Brasil, o que demonstra a relevância e motivo de escolha da mesma. 
Tendo como base o caminho trilhado por Miranda (2010), no dia 06 de Julho de 2015 foi criado um perfil para esta pesquisa na rede social LinkedIn. No dia 07 de Julho de 2015, antes da busca efetiva por estes profissionais de controladoria, optou-se por solicitar ingresso em grupos e comunidades no LinkedIn relacionados com Controladoria. Isto com o objetivo de ampliar a rede de contatos possível.

A forma de encontrar esses profissionais se deu através do campo de busca da rede social, utilizando a palavra-chave "controller" (Grifo nosso). Em seguida, verificou-se no perfil declarado se o mesmo, de fato, era um profissional ligado a área de Controladoria. Para que se mantenha contato com esses profissionais é necessário que estes aceitem um convite de solicitação de amizade. Nesta solicitação, deve-se informar o motivo do relacionamento. Para tanto, foi escrito um texto explicando o motivo do contato e o objetivo da pesquisa.

No dia 08 de Julho de 2015 iniciou-se a busca por estes perfis e as solicitações de contato. Em 12 dias foram encaminhados 1.012 solicitações de contatos, dos quais 568 aceitaram o convite. $\mathrm{Na}$ medida em que os aceites ocorriam, eram encaminhados os formulários de coleta, para cada profissional. Foram enviadas três ondas de solicitação de respostas, que se iniciaram em 09 de julho de 2015 e se encerraram em 28 de agosto de 2015. Após esse período, ainda houve aceites de convite e, consequentemente, novos envios de formulários, em 01 de setembro de 2015 e em 09 de outubro de 2015.

Ao fim desse período, foram recebidas 241 respostas, dos 568 profissionais que aceitaram responder o questionário. Ou seja, uma taxa de retorno de $42 \%$.

Após o recebimento dos 241 questionários, iniciou-se o processo de depuração dos dados sob dois enfoques: inconsistência das informações e respostas extremas. Neste processo, foram excluídas 33 respostas, restando um total de 208 questionários validados, número de respostas próximo ao da base de Miranda (2010), que foi de 212.

\subsection{INSTRUMENTO DE COLETA DE DADOS}

Os dados para esta pesquisa foram obtidos através de um questionário eletrônico elaborado e alocado na ferramenta Google Drive, no seguinte endereço: https://docs.google.com/forms/d/1UC26efNqKIMui9ZG30PwiwqpFUmcT3oiAwbJ3yacwBA /viewform

O Instrumento foi estruturado em 03 blocos, a saber: Bloco 01 - Competência dos Controllers em escala de importância; Bloco 02 - Experiências essenciais no desenvolvimento de um Controller; e Bloco 03 - Perfil do respondente. Esta ordem teve como base os 
princípios ensinados por Günther (2003) para estruturação e sequência de um questionário, do mais geral para o mais específico, do menos pessoal e delicado para o mais.

As informações que serão expostas, sobre a estrutura do questionário, referem-se à versão final desenvolvida após a aplicação de 4 pré-testes. Os pré-testes foram submetidos a 2 profissionais da área de controladoria, 1 profissional da área de contabilidade e 1 pesquisador, especialista em questionários, da área de psicologia. Com esses pré-testes foi possível trazer mais clareza a algumas perguntas e estruturar melhor o questionário.

No Bloco 01 - Competência dos Controllers em escala de importância, o objetivo foi identificar, na visão dos respondentes, quais eram as competências mais importantes no desempenho desta função. As 12 competências listadas foram definidas, partindo do estudo de Cardoso et al (2010), e agregando elementos dos trabalhos de Machado et al (2010) e de Araújo, Callado e Cavalcanti (2014), conforme explicita o Quadro 7 - Competências dos Controllers. Além de serem estudos mais recentes, estas três pesquisas objetivaram identificar as competências dos Controllers.

Quadro 7: Competências dos Controllers

\begin{tabular}{|l|c|c|c|}
\hline \multicolumn{1}{|c|}{ Competências } & $\begin{array}{c}\text { Cardoso et al } \\
(\mathbf{2 0 1 0})\end{array}$ & $\begin{array}{c}\text { Machado et al } \\
(\mathbf{2 0 1 0})\end{array}$ & $\begin{array}{c}\text { Araújo, Callado, } \\
\text { Cavalcanti (2014) }\end{array}$ \\
\hline Autocontrole & $\mathrm{X}$ & & $\mathrm{X}$ \\
\hline Capacidade analítica & $\mathrm{X}$ & $\mathrm{X}$ & $\mathrm{X}$ \\
\hline Contabilidade e finanças & $\mathrm{X}$ & $\mathrm{X}$ & $\mathrm{X}$ \\
\hline Empreendedora & $\mathrm{X}$ & & $\mathrm{X}$ \\
\hline Ferramentas de controle & $\mathrm{X}$ & & \\
\hline Gestão da Informação & $\mathrm{X}$ & & $\mathrm{X}$ \\
\hline Conhecimento Legal & $\mathrm{X}$ & $\mathrm{X}$ & \\
\hline Ouvir eficazmente & $\mathrm{X}$ & & $\mathrm{X}$ \\
\hline Planejamento & $\mathrm{X}$ & $\mathrm{X}$ & $\mathrm{X}$ \\
\hline Relacionamento externo & $\mathrm{X}$ & $\mathrm{X}$ & \\
\hline Trabalho em Equipe & $\mathrm{X}$ & $\mathrm{X}$ & \\
\hline Visão Estratégica & & & \\
\hline
\end{tabular}

Fonte: Dados da pesquisa, 2015.

A pergunta 01, incluída neste bloco inicial, foi estruturada para permitir uma graduação das respostas, de forma escalar, com cinco pontos tipo Likert: Nenhuma Importância; Pouca Importância; Importante; Muito Importante; Indispensável. Ainda foi incluída uma opção de "Não Sei Avaliar".

O Bloco 02 - Experiências essenciais no desenvolvimento de um Controller, está estruturado com cinco perguntas, sendo quatro fechadas e uma aberta. A orientação deste 
bloco parte do entendimento de Le Boterf (2003) sobre o desenvolvimento de competências, que pode ser através de cinco vivências distintas: (1) a educação formal, que seria a escolar, básica; (2) a formação inicial, a graduação em um curso de ensino superior; (3) a formação contínua, cursos de pós-graduação e treinamentos; (4) as experiências profissionais, os estágios e empregos anteriores; e (5) as experiências sociais.

A pergunta 02 pede para que cada respondente ordene essas vivências em grau de importância para o desempenho de seu trabalho como Controller.

As perguntas na sequência deste bloco buscam aprofundar o entendimento sobre estas vivências. A pergunta 03, fechada, pede para que sejam listados os cinco conteúdos de disciplinas, de formação inicial ou contínua, mais relevantes no desempenho da função de Controller. A pergunta 04, também fechada, busca trazer as experiências profissionais que mais contribuíram para este profissional ter se tornado um Controller, articulando a área de atuação e o nível do cargo. A pergunta 05 é aberta, e pede para o respondente dizer qual a experiência profissional mais importante e por que.

O último e $3^{\circ}$ bloco teve como objetivo traçar o perfil dos Controllers que responderam a pesquisa e, também, das empresas nas quais eles trabalham. Este tipo de caracterização é importante, pois ajuda a entender as respostas em função das características dos respondentes. Estas perguntas, além de fazer esta caracterização, também trazem informações importantes sobre a formação destes profissionais (graduação e pós-graduação) e da trajetória profissional (tempo de carreira total, tempo de carreira como Controller e nível hierárquico como Controller).

\subsection{PROCEDIMENTOS DE ANÁLISE DOS DADOS}

Foram recebidas, através do questionário eletrônico do Google Drive, respostas até o dia 27 de outubro de 2015. Essas informações foram baixadas em formato de planilha eletrônica, recurso disponível na própria ferramenta, para assim serem tratados. Após tratamento inicial, foi constituído um banco de dados em software específico de estatística, o IBM SPSS Statistics 20.

Visto que a Pergunta 01 foi estruturada para permitir uma graduação das respostas, tipo Likert, foi preciso fazer uma análise da consistência interna utilizando o Alfa de Cronbach como medida de confiabilidade. Conforme explicam Hair et al (2006), a consistência interna parte do princípio que os indicadores individuais de uma escala devem medir o mesmo construto, sendo assim altamente intercorrelacionados. Ainda segundo os 
autores, para este tipo de avaliação, o Alfa de Cronbach é a medida mais utilizada. Ela gera um resultado variando de 0 a 1 , onde são aceitos resultados quando o alfa for superior a 0,70 .

Quadro 8: Alfa de Cronbach

\begin{tabular}{|c|c|c|}
\hline Cronbach's Alpha & $\begin{array}{c}\text { Cronbach's Alpha Based on } \\
\text { Standardized Items }\end{array}$ & $N$ of Items \\
\hline ,773 &, 770 & 12 \\
\hline
\end{tabular}

Fonte: Dados da pesquisa, 2015.

O Alfa de Cronbach calculado para esta pergunta do questionário foi de 0,773 , conforme demostra o Quadro 8, indicando uma boa consistência interna.

Os dados foram submetidos a análises de estatística descritiva e inferencial. Neste último caso, todas as variáveis foram computadas como nominais a fim de serem testadas correlações por meio do $\chi^{2}$ (qui-quadrado). Dado o tamanho reduzido da amostra, foi necessário recorrer ao teste exato de Fisher, considerando o $p$ valor menor ou igual a 0,050 (BELFIORE, 2015). 


\section{ANÁLISE DOS RESULTADOS}

\subsection{PERFIL DOS CONTROLLERS}

Baseando-se nas informações obtidas pelo instrumento de coleta têm-se, como caracterização dos respondentes, as informações a seguir.

Quanto ao sexo dos respondentes, conforme o Gráfico 1, a maioria dos deles é do sexo masculino, com $82 \%$ do total.

Gráfico 1: Sexo dos respondentes

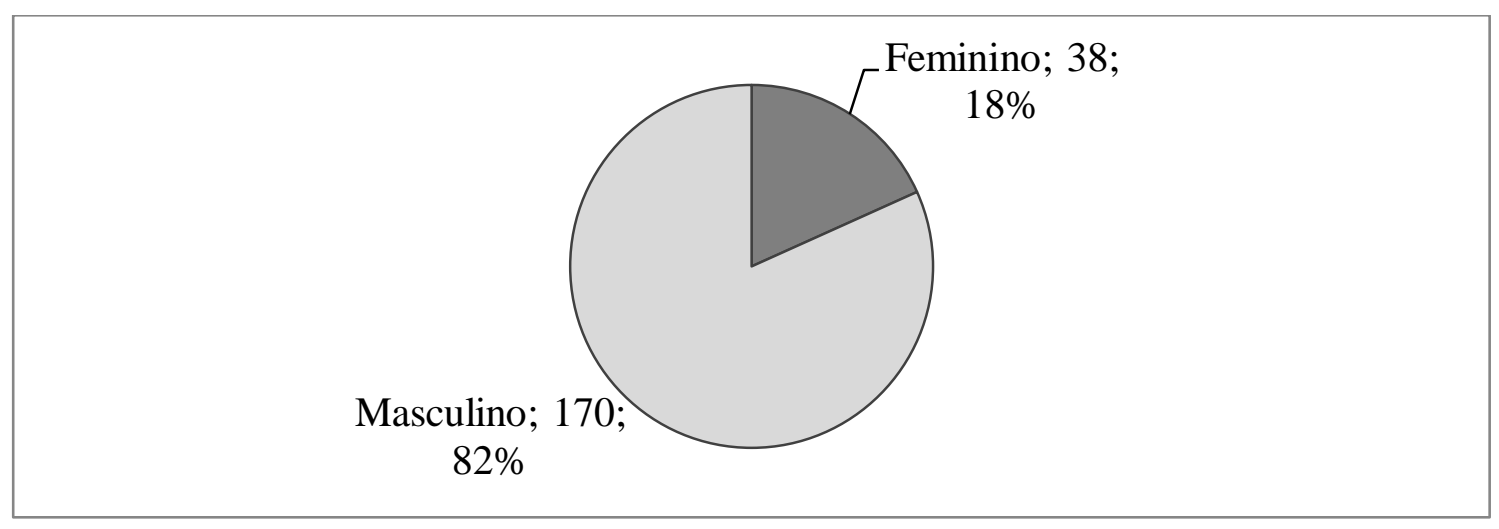

Fonte: Dados da pesquisa, 2015.

Com relação à faixa etária, como demonstra o Gráfico $2,51 \%$ dos respondentes $(\mathrm{n}=$ 106) têm de 30 a 39 anos. Em seguida, figuram os profissionais na faixa etária de 40 a 49 anos, com $36 \%$ do total $(\mathrm{n}=74)$.

Gráfico 2: Faixa Etária

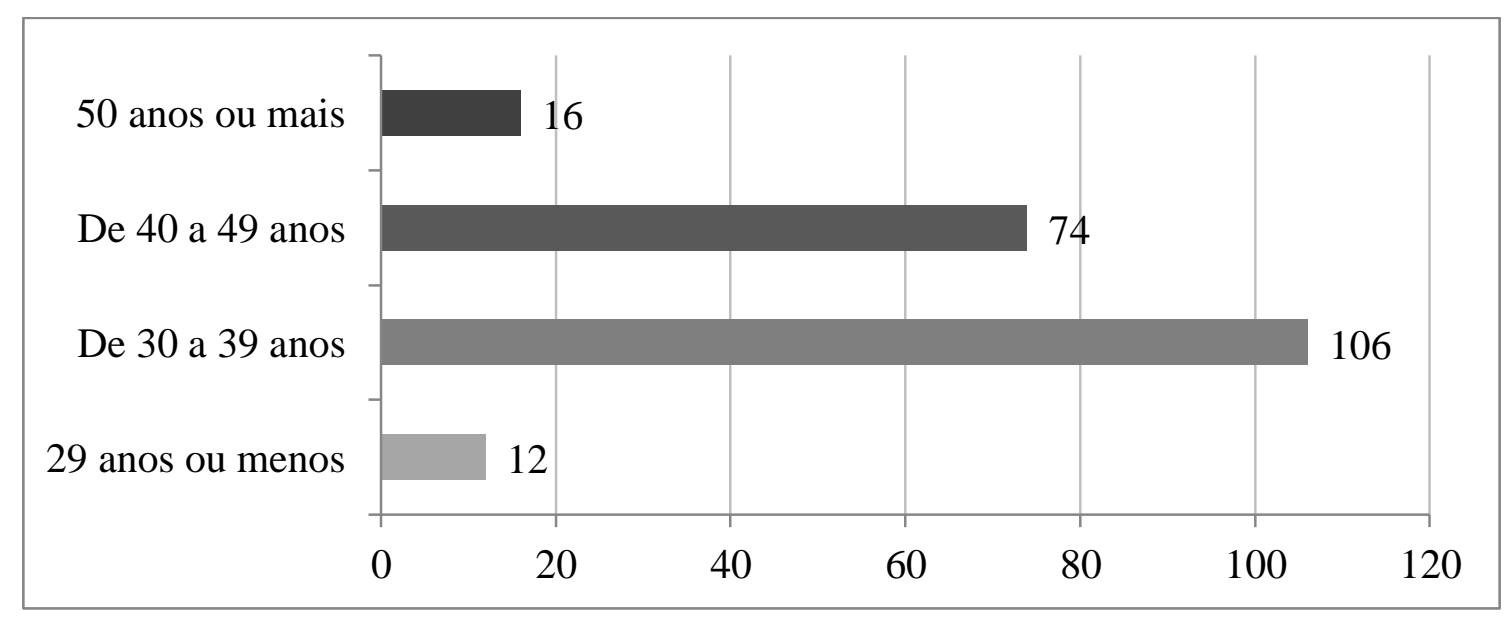

Fonte: Dados da pesquisa, 2015. 
Quanto à formação de ensino superior, observou-se que a maioria dos respondentes tem sua graduação ligada a área de negócios, principalmente dos cursos de Contabilidade e Administração. Conforme pode ser ponderado através de uma análise mais detalhada da Tabela 1, incluindo os profissionais que possuem duas graduações, o número de respondentes com formação em Ciências Contábeis perfaz o total de 133, ou 64\% do total. Esta informação está alinhada com os trabalhos recentes de Dal Vasco, Daniel e Tarifa (2014), de Ferreira et al (2014) e de Gomes, Souza e Lunkes (2014), indicando que a maioria dos profissionais de Controladoria ainda são formados em Contabilidade.

Tabela 1: Formação de ensino superior

\begin{tabular}{l|r|r}
\hline \multicolumn{1}{c|}{ Formação - Graduação } & Frequência & \multicolumn{1}{c}{$\%$} \\
\hline Ciências Contábeis & 104 & $50,00 \%$ \\
\hline Administração & 45 & $21,63 \%$ \\
\hline Administração; Ciências Contábeis & 20 & $9,62 \%$ \\
\hline Economia & 18 & $8,65 \%$ \\
\hline Ciências Contábeis; Economia & 05 & $2,40 \%$ \\
\hline Ciências Contábeis; Direito & 04 & $1,92 \%$ \\
\hline Engenharia Eletrônica & 02 & $0,96 \%$ \\
\hline Outros & 10 & $4,81 \%$ \\
\hline Total & $\mathbf{2 0 8}$ & $\mathbf{1 0 0 \%}$ \\
\hline
\end{tabular}

Fonte: Dados da pesquisa, 2015.

A Tabela 2 demonstra os cursos e as áreas de formação de pós-graduação dos respondentes. No total, foram contabilizadas 434 combinações de respostas. Este número é superior ao de respondentes, porque estes tinham mais de uma formação em cursos de pósgraduação. Os tipos de cursos com mais ocorrência são as especialização Lato Sensu e MBA, acumulando $90 \%(n=394)$. Outro detalhe, com relação aos tipos de cursos de formação em pós-graduação, somente um respondente tem Doutorado, na área de Administração. Quanto às áreas de formação, as principais são Controladoria com 25\% (n=110) e Tributária com 22\% ( $\mathrm{n}=98)$. O curso de especialização tipo MBA em controladoria foi o mais citado pelos respondentes $(\mathrm{n}=75)$.

Segundo o Conselho Nacional de Educação (2001), os cursos denominados como MBA (Master Business Administration) são um tipo especialização Lato Sensu. No entanto, visto que as instituições de ensino fazem distinção entre cursos Especialização Lato Sensu e MBA, neste trabalho preferiu-se fazer esta divisão. 
Tabela 2: Formação de pós-graduação

\begin{tabular}{l|r|r|r|r|r|r}
\hline & $\begin{array}{c}\text { Esp. Lato } \\
\text { Sensu }\end{array}$ & $\begin{array}{c}\text { Esp. } \\
\text { MBA }\end{array}$ & $\begin{array}{c}\text { Mestrado } \\
\text { Profissional }\end{array}$ & $\begin{array}{c}\text { Mestrado } \\
\text { Acadêmico }\end{array}$ & Doutorado & $\begin{array}{c}\text { Total } \\
\text { Áreas }\end{array}$ \\
\hline Controladoria & 31 & 75 & 03 & 01 & - & $\mathbf{1 1 0}$ \\
\hline Finanças & 27 & 68 & 03 & - & - & $\mathbf{9 8}$ \\
\hline Administração & 27 & 39 & 09 & 02 & 01 & $\mathbf{7 8}$ \\
\hline Ciências Contábeis & 24 & 10 & 02 & 09 & - & $\mathbf{4 5}$ \\
\hline Auditoria & 08 & 25 & 01 & 02 & - & $\mathbf{3 6}$ \\
\hline Tributária & 08 & 13 & 00 & - & - & $\mathbf{2 1}$ \\
\hline Gestão de pessoal & 08 & 09 & 01 & - & - & $\mathbf{1 8}$ \\
\hline Economia & 06 & 04 & 04 & - & - & $\mathbf{1 4}$ \\
\hline $\begin{array}{l}\text { Sistemas de } \\
\text { Informação }\end{array}$ & 05 & 03 & 01 & - & - & $\mathbf{0 9}$ \\
\hline $\begin{array}{l}\text { Engenharia de } \\
\text { produção }\end{array}$ & - & 04 & 01 & - & - & $\mathbf{0 5}$ \\
\hline Total Cursos & $\mathbf{1 4 4}$ & $\mathbf{2 5 0}$ & $\mathbf{2 5}$ & $\mathbf{1 4}$ & $\mathbf{0 1}$ & $\mathbf{4 3 4}$ \\
\hline
\end{tabular}

Fonte: Dados da pesquisa, 2015.

Ainda com relação à formação de pós-graduação dos respondentes, o Gráfico 3 traz um panorama por nível do curso.

Gráfico 3: Formação de pós-graduação, por nível do curso

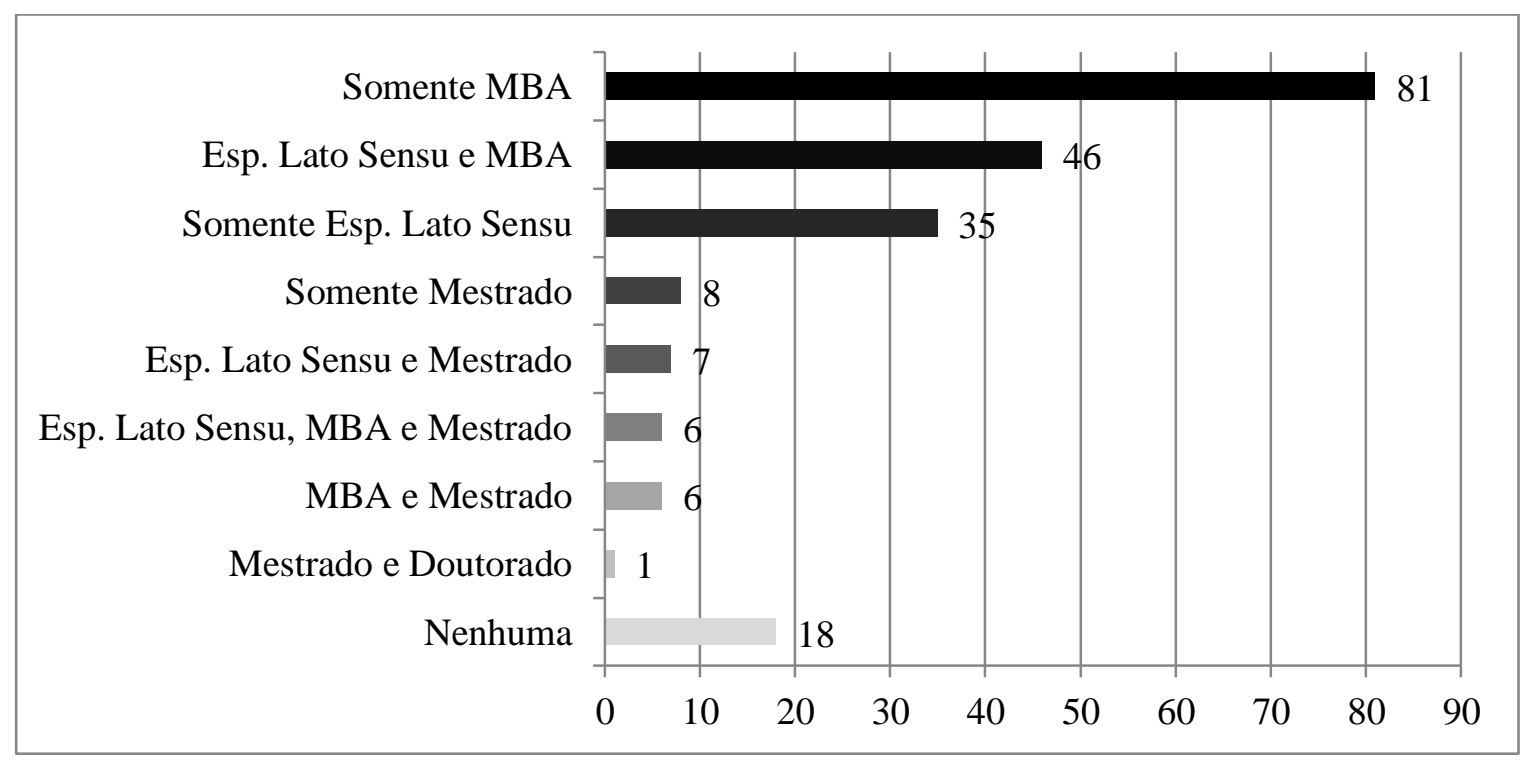

Fonte: Dados da pesquisa, 2015.

A maioria dos respondentes, $78 \%(\mathrm{n}=162)$ tem, somente, pós-graduação em cursos de especialização, seja ele Lato Sensu, MBA ou ambos. Os respondentes que assinalaram ter, ao 
menos o Mestrado, totalizaram 13\% $(\mathrm{n}=28)$. Somente $9 \%$ dos respondentes $(\mathrm{n}=18)$ disseram não ter nenhuma formação de pós-graduação.

Este detalhamento por nível de curso se faz relevante, pois, é a partir da pósgraduação, que existe uma diferenciação dos respondentes com relação ao nível de formação. Como pode ser verificado na Tabela 1, todos eles têm formação incial (graduação) em algum curso de nível superior e, consequentemente, escolar básica. Porém, no nível de pósgraduação, além de existirem cursos do tipo Lato Sensu e Stricto Sensu, alguns respondentes disseram não possuir este nível de formação.

Assim como nos cursos de formação de pós-graduação, o número de respostas, para o domínio de língua estrangeira (Tabela 3), foi superior ao número de respondentes. No total foram 315 respostas, onde 59,37\% $(n=187)$ disseram ter domínio da língua inglesa e 25,71\% $(\mathrm{n}=81)$ domínio do espanhol. Essas duas línguas estrangeiras representam $85 \%$ das respostas. Ademais, ressalta-se que 5,08\% dos respondentes $(\mathrm{n}=16)$ disseram não dominar nenhuma língua estrangeira.

Tabela 3: Domínio de língua estrangeira

\begin{tabular}{l|r|r}
\hline \multicolumn{1}{c|}{ Língua } & Frequência & \multicolumn{1}{c}{$\%$} \\
\hline Inglês & 187 & $59,37 \%$ \\
\hline Espanhol & 81 & $25,71 \%$ \\
\hline Francês & 12 & $3,81 \%$ \\
\hline Alemão & 09 & $2,86 \%$ \\
\hline Italiano & 09 & $2,86 \%$ \\
\hline Chinês & 01 & $0,32 \%$ \\
\hline Nenhuma & 16 & $5,08 \%$ \\
\hline Total & $\mathbf{3 1 5}$ & $\mathbf{1 0 0 \%}$ \\
\hline
\end{tabular}

Fonte: Dados da pesquisa, 2015.

O Gráfico 4 demonstra o tempo de carreira total dos respondentes. A grande maioria dos respondentes, total de $90 \%$, tem mais de 10 anos de carreira, sendo $29 \%(\mathrm{n}=61)$ na faixa de 11 a 15 anos, $25 \%(n=51)$ na faixa de 16 a 20 anos e $37 \%(n=76)$ com mais de 20 anos. 
Gráfico 4: Tempo de carreira total

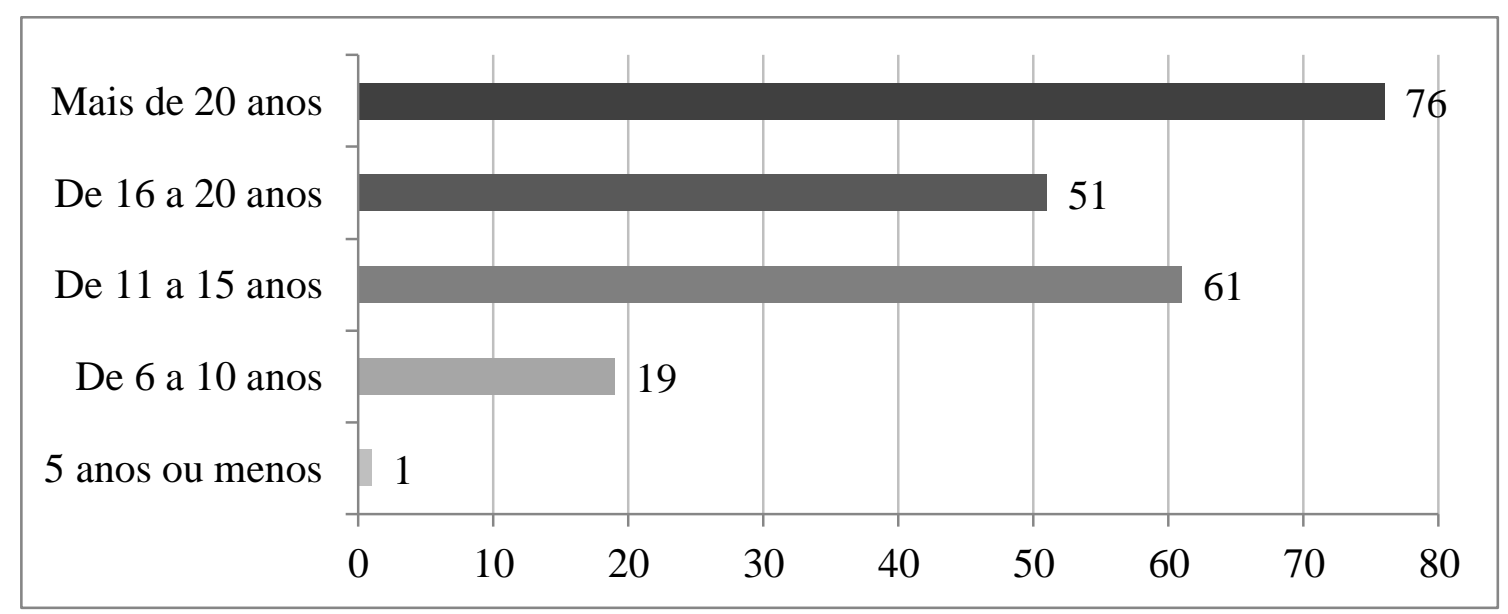

Fonte: Dados da pesquisa, 2015.

Com relação ao tempo de carreira como Controller, conforme o Gráfico 5, a situação se inverte. A maioria dos respondentes, $78 \%$, tem menos de 10 anos de carreira como profissional de Controladoria. De 6 a 10 anos de carreira são 38\% $(\mathrm{n}=78)$ e com menos de 5 anos são $40 \%(\mathrm{n}=84)$.

Pode-se ponderar com essas informações que a ocupação da função de Controller está relacionada a um tempo de experiência prévio, ou seja, os profissionais primeiro desenvolvem uma trajetória em outros cargos para só então seguirem essa carreira.

Gráfico 5: Tempo de carreira como Controller

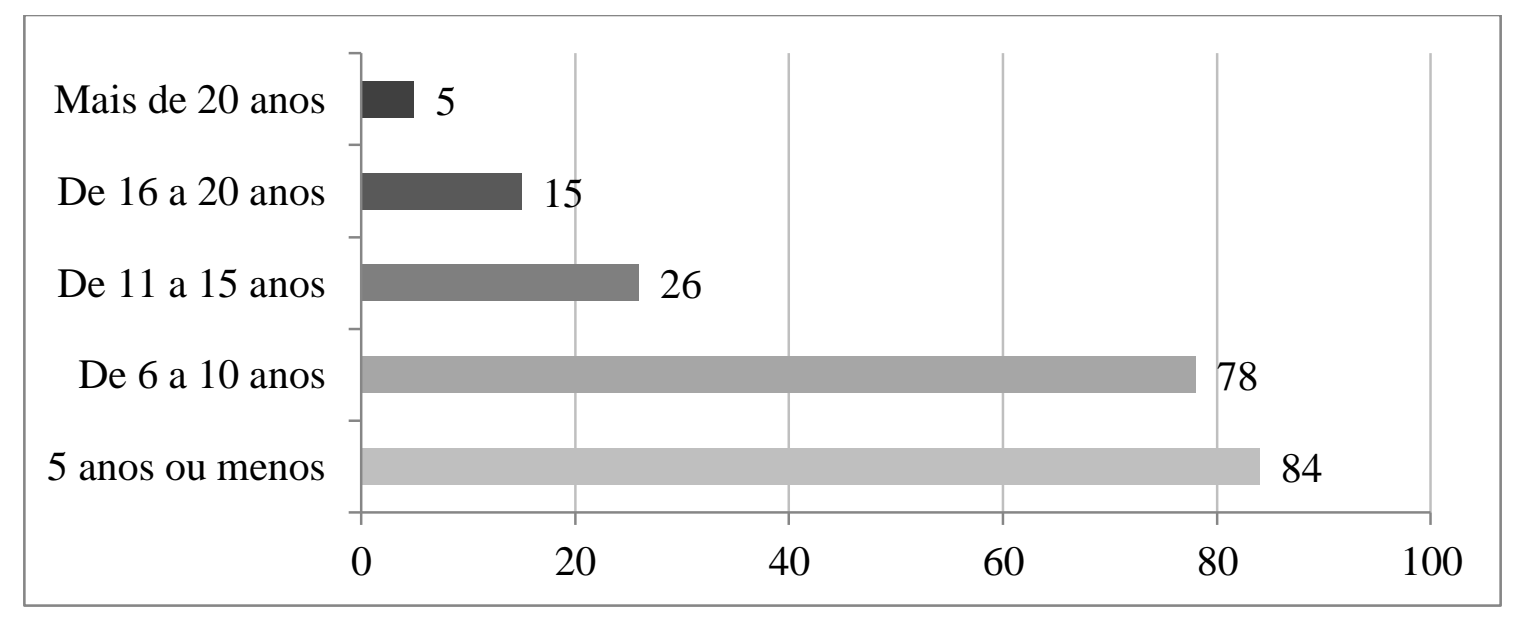

Fonte: Dados da pesquisa, 2015.

Quanto ao nível hierárquico desses Controllers dentro das empresas, Gráfico 6, a maioria deles ocupa cargos de Gerência, um total de $60 \%(n=125)$. 
Gráfico 6: Nível hierárquico como Controller

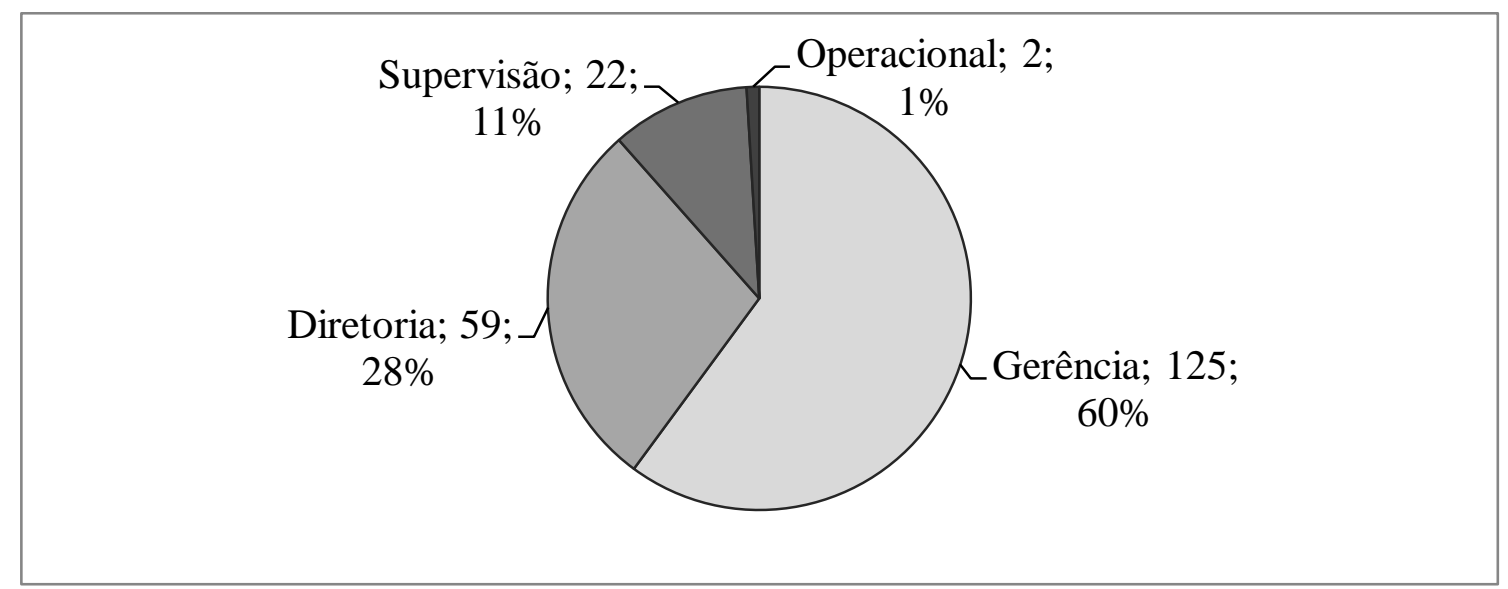

Fonte: Dados da pesquisa, 2015.

Esta variedade de níveis hierárquicos ocupados pelos Controllers é uma característica nesta função. Conforme demonstraram os resultados do trabalho de Coelho, Lunkes e Machado (2012), não há consenso da classificação hierárquica e do nível de autoridade na controladoria. Segundo os achados da pesquisa mencionada, a controladoria pode se apresentar tanto como órgão de staff relacionado diretamente com a alta administração, tanto como um órgão de linha, de posição intermediária, subordinada a direção financeira da empresa.

Com relação à Unidade da Federação (UF) de trabalho dos respondentes, conforme demonstra a Tabela 4, a grande maioria deles, 69,23\% $(\mathrm{n}=144)$, trabalha na região sudeste. $\mathrm{O}$ estado com o maior número de respondentes foi São Paulo, perfazendo um total de 117 (56\%). Somente 17 respondentes $(8,17 \%)$ trabalham na região Nordeste, sendo um deles do Rio Grande Norte.

O trabalho de Gomes, Souza e Lunkes (2014), que estudou o perfil do profissional da controladoria através de anúncios de vagas de emprego, trouxe números similares quanto às UF's e regiões de trabalho. Isto indica que a distribuição por UF dos respondentes desta pesquisa está alinhada com as vagas disponíveis no mercado e, consequentemente, com a região onde estes atuam. 
Tabela 4: UF e região de trabalho

\begin{tabular}{|c|c|c|c|c|}
\hline Região & $\mathbf{U F}$ & $\begin{array}{l}\text { Quantidade } \\
\text { por estado }\end{array}$ & $\begin{array}{l}\text { Quantidade } \\
\text { por região }\end{array}$ & \% por região \\
\hline \multirow{4}{*}{ Sudeste } & São Paulo & 117 & \multirow{4}{*}{144} & \multirow{4}{*}{$69,23 \%$} \\
\hline & Minas Gerais & 17 & & \\
\hline & Rio de Janeiro & 09 & & \\
\hline & Espirito Santo & 01 & & \\
\hline \multirow{3}{*}{ Sul } & Paraná & 14 & \multirow{3}{*}{34} & \multirow{3}{*}{$16,35 \%$} \\
\hline & Santa Catarina & 14 & & \\
\hline & Rio Grande do Sul & 06 & & \\
\hline \multirow{4}{*}{ Nordeste } & Pernambuco & 09 & \multirow{4}{*}{17} & \multirow{4}{*}{$8,17 \%$} \\
\hline & Bahia & 05 & & \\
\hline & Ceara & 02 & & \\
\hline & Rio Grande do Norte & 01 & & \\
\hline \multirow{4}{*}{ Centro-oeste } & Goiás & 07 & \multirow{4}{*}{10} & \multirow{4}{*}{$4,81 \%$} \\
\hline & Distrito Federal & 01 & & \\
\hline & Mato Grosso & 01 & & \\
\hline & Tocantins & 01 & & \\
\hline Norte & Amazonas & 03 & 03 & $1,44 \%$ \\
\hline & Total & 208 & 208 & $100 \%$ \\
\hline
\end{tabular}

Fonte: Dados da pesquisa, 2015.

Quanto ao perfil das empresas onde estes Controllers desempenham sua função, a Tabela 5 demonstra o setor de atividade destas.

Tabela 5: Setor de atividade da empresa

\begin{tabular}{l|r|r}
\hline \multicolumn{1}{c|}{ Setor de Atividade } & Frequência & \multicolumn{1}{c}{$\%$} \\
\hline Indústria & 112 & $53,85 \%$ \\
\hline Serviço & 36 & $17,31 \%$ \\
\hline Comércio & 25 & $12,02 \%$ \\
\hline Agropecuário & 12 & $5,77 \%$ \\
\hline Tecnologia & 07 & $3,37 \%$ \\
\hline Financeiro & 06 & $2,88 \%$ \\
\hline Construção Civil & 03 & $1,44 \%$ \\
\hline Mineração & 03 & $1,44 \%$ \\
\hline Terceiro Setor & 02 & $0,96 \%$ \\
\hline Editorial & 01 & $0,48 \%$ \\
\hline Energia & 01 & $0,48 \%$ \\
\hline Total & $\mathbf{2 0 8}$ & $\mathbf{1 0 0 \%}$ \\
\hline
\end{tabular}

Fonte: Dados da pesquisa, 2015. 
Pouco mais da metade dos respondentes $(53,85 \%)$, trabalham em empresas do setor industrial. Na sequência, os setores mais citados foram o de serviços $(17,31 \%)$ e o de comércio $(12,02 \%)$.

A dissertação de Ferreira (2011), que estudou os anúncios de recrutamento e seleção para Controllers, demonstra resultados similares aos acima expostos. O setor de atividade das empresas, conforme o trabalho supracitado, com um maior número de anúncios de vagas foi o da indústria, seguido do comércio, segundo lugar, e de serviços, terceiro.

Ainda com relação ao perfil, o Gráfico 7 revela o porte das empresas onde os respondentes trabalham. Esta classificação foi feita levando em consideração o número de funcionários de cada empresa, e com base no critério do Sebrae para esta distinção. A saber: a) Nas indústrias: Até 99 funcionários - pequena empresa, De 100 a 499 funcionários - média empresa, 500 ou mais funcionários - grande empresa; b) Comércio e serviços: a) Até 49 funcionários - pequena empresa, b) De 50 a 99 funcionários - média empresa, c) 100 ou mais funcionários - grande empresa.

\section{Gráfico 7: Porte das empresas}

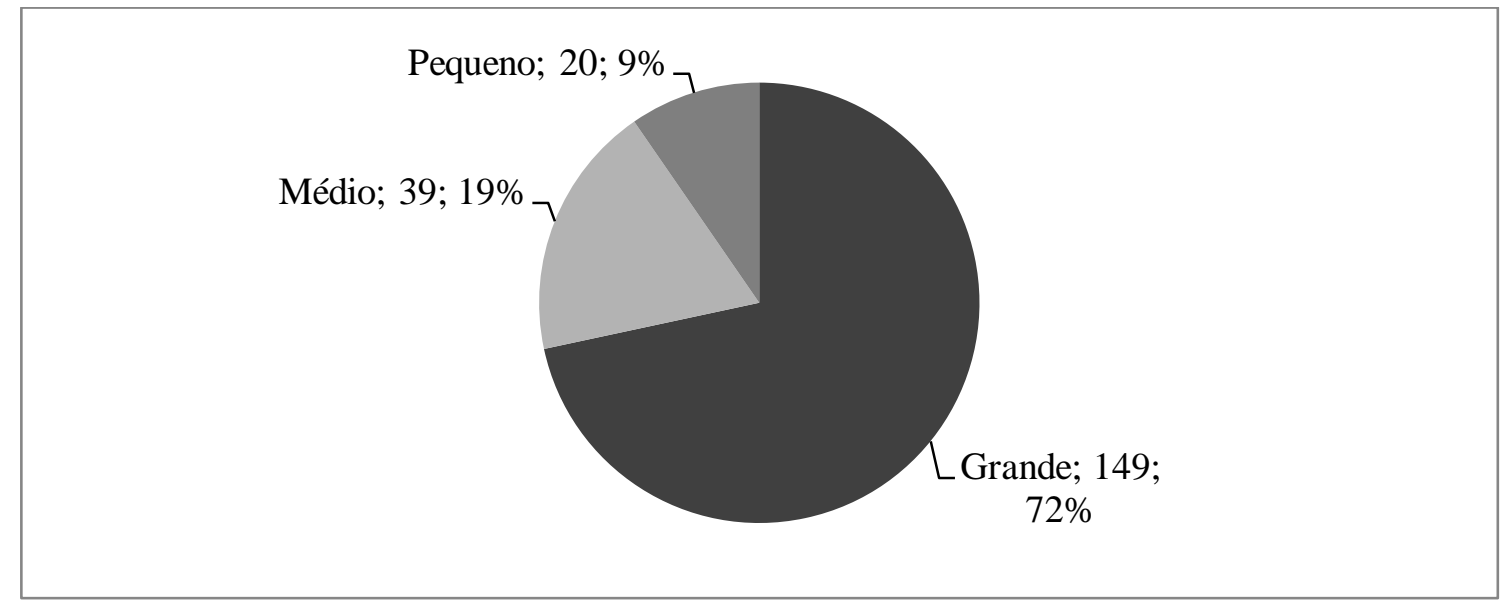

Fonte: Dados da pesquisa, 2015.

A maioria dos respondentes, $72 \%(n=149)$, disseram trabalhar em empresas de grande porte. Segundo Martins et al (2013), a utilização de ferramentas ligadas ao segmento gerencial da contabilidade, como as que a Controladoria faz uso, incrementam o custo das empresas, pois é preciso possuir um setor específico para isso. Desta feita, não é de se estranhar que a maioria dos respondentes desta pesquisa estejam alocados em empresas de maior porte e, consequentemente, uma maior estrutura. 


\subsection{DESENVOLVIMENTO DE COMPETÊNCIAS}

Conforme exposto, existem vários estudos na literatura com o objetivo de identificar e analisar as competências de um Controller, tais como o de Cardoso et al (2010), Machado et al (2010), Maciel e Lima (2011), Ferrari et al (2013), Araújo, Callado e Cavalcanti (2014), Gomes, Souza e Lunkes (2014). A proposta desse bloco é trazer uma avaliação dos próprios Controllers destas competências.

Assim, a tabela 6 traz as competências dos Controllers, em grau de importância, segundo os respondentes. De início, é importante ressaltar que nenhum respondente considerou as competências listadas como de "Nenhuma Importância". Por este motivo, não foi incluída uma coluna com esta opção na tabela. O número de respondentes que consideraram, ao menos, uma das competências listadas como de "Pouca Importância", foi baixo $(2,6 \%)$. A grande maioria dos respondentes $(97,4 \%)$ consideraram as competências listadas como "Importante", "Muito Importante" ou "Indispensável".

Tabela 6: Competências dos Controllers em grau de importância

\begin{tabular}{l|c|c|c|c|c|c|c|c}
\hline \multirow{2}{*}{\begin{tabular}{l}
\multirow{2}{*}{ Competências } \\
\cline { 2 - 9 }
\end{tabular}} & \multicolumn{2}{c|}{$\begin{array}{c}\text { Pouca } \\
\text { Importância }\end{array}$} & \multicolumn{2}{c|}{ Importante } & \multicolumn{2}{c|}{$\begin{array}{c}\text { Muito } \\
\text { Importante }\end{array}$} & \multicolumn{2}{c}{ Indispensável } \\
\cline { 2 - 10 } & $\mathbf{N}$ & $\mathbf{\%}$ & $\mathbf{n}$ & $\mathbf{\%}$ & $\mathbf{n}$ & $\mathbf{\%}$ & $\mathbf{n}$ & $\mathbf{\%}$ \\
\hline Autocontrole & 01 & $0,5 \%$ & 49 & $23,6 \%$ & $\mathbf{9 0}$ & $\mathbf{4 3 , 3 \%}$ & 68 & $32,7 \%$ \\
\hline Capacidade analítica & - & $0,0 \%$ & 06 & $2,9 \%$ & 68 & $32,7 \%$ & $\mathbf{1 3 4}$ & $\mathbf{6 4 , 4 \%}$ \\
\hline $\begin{array}{l}\text { Contabilidade e } \\
\text { finanças }\end{array}$ & - & $0,0 \%$ & 15 & $7,2 \%$ & 70 & $33,7 \%$ & $\mathbf{1 2 3}$ & $\mathbf{5 9 , 1 \%}$ \\
\hline Empreendedora & 39 & $18,8 \%$ & $\mathbf{1 0 4}$ & $\mathbf{5 0 , 0 \%}$ & 53 & $25,5 \%$ & 12 & $5,8 \%$ \\
\hline $\begin{array}{l}\text { Ferramentas de } \\
\text { controle }\end{array}$ & 02 & $1,0 \%$ & 25 & $12,0 \%$ & $\mathbf{1 0 2}$ & $\mathbf{4 9 , 0 \%}$ & 79 & $38,0 \%$ \\
\hline $\begin{array}{l}\text { Gestão da } \\
\text { Informação }\end{array}$ & 02 & $1,0 \%$ & 36 & $17,3 \%$ & $\mathbf{9 8}$ & $\mathbf{4 7 , 1 \%}$ & 72 & $34,6 \%$ \\
\hline Conhecimento Legal & 10 & $4,8 \%$ & $\mathbf{1 0 2}$ & $\mathbf{4 9 , 0 \%}$ & 74 & $35,6 \%$ & 22 & $10,6 \%$ \\
\hline Ouvir eficazmente & 01 & $0,5 \%$ & 52 & $25,0 \%$ & $\mathbf{9 7}$ & $\mathbf{4 6 , 6 \%}$ & 58 & $27,9 \%$ \\
\hline Planejamento & - & $0,0 \%$ & 17 & $8,2 \%$ & 86 & $41,3 \%$ & $\mathbf{1 0 5}$ & $\mathbf{5 0 , 5 \%}$ \\
\hline $\begin{array}{l}\text { Relacionamento } \\
\text { externo }\end{array}$ & 09 & $4,3 \%$ & 77 & $37,0 \%$ & $\mathbf{8 6}$ & $\mathbf{4 1 , 3 \%}$ & 36 & $17,3 \%$ \\
\hline Trabalho em Equipe & - & $0,0 \%$ & 30 & $14,4 \%$ & 79 & $38,0 \%$ & $\mathbf{9 9}$ & $\mathbf{4 7 , 6 \%}$ \\
\hline Visão Estratégica & 01 & $0,5 \%$ & 09 & $4,3 \%$ & 69 & $33,2 \%$ & $\mathbf{1 2 9}$ & $\mathbf{6 2 , 0 \%}$ \\
\hline Total & $\mathbf{6 5}$ & $\mathbf{2 , 6 \%}$ & $\mathbf{5 2 2}$ & $\mathbf{2 0 , 9 \%}$ & $\mathbf{9 7 2}$ & $\mathbf{3 8 , 9 \%}$ & $\mathbf{9 3 7}$ & $\mathbf{3 7 , 5 \%}$ \\
\hline
\end{tabular}

Fonte: Dados da pesquisa, 2015. 
No total, cinco competências foram citadas, com mais frequência, entre as “indispensáveis", são elas: Capacidade analítica (64,4\%); Contabilidade e finanças $(59,1 \%)$, Planejamento (50,5\%), Trabalho em equipe (47,6\%) e Visão estratégica (62,0\%). Segundo Cardoso et al (2010), as competências de Capacidade analítica, Contabilidade e finanças e Planejamento estão relacionadas a aspectos técnicos, já a competência de Trabalho em equipe relaciona-se a dimensões comportamentais e, por fim, Visão estratégica diz respeito a características de postura.

É possível, com base nas informações expostas, fazer uma relação dessas competências com o que preconiza Le Boterf (2003) e Fleury e Fleury (2007), acerca do processo de desenvolvimento de competência. Segundo estes autores, competências como Capacidade analítica, Contabilidade e finanças e Planejamento, classificadas como conhecimentos técnicos, são adquiridas através de educação formal ou formação inicial e contínua. Com relação às competências comportamentais, como o trabalho em equipe, são adquiridas através de experiências profissionais e sociais. Por fim, quanto às competências de postura, como a visão estratégica, se desenvolvem através de formação inicial e da experiência profissional.

Ainda dentro da análise sobre desenvolvimento de competências, foi utilizado o teste exato de Fischer para verificar correlações entre a avaliação da importância das competências pelos respondentes e o tempo de carreira como Controller. O objetivo desta análise é verificar se a trajetória em anos de trabalho como Controller guarda alguma relação com a percepção dos mesmos acerca das competências mais importantes no desempenho de sua função.

Desta maneira, foi possível verificar que a atuação como Controller por um período de 06 a 10 anos apresentou correlação estatisticamente significativa com as classificações das competências de Empreendedorismo como Indispensável $(p=0,034)$ e de Conhecimento Legal como Muito Importante $(p=0,011)$. Além disso, foi constatado que ter tempo de carreira como Controller por um intervalo de 11 a 15 anos apresentou correlação significativa com a avaliação das competências de Auto Controle $(p=0,019)$ e de Conhecimento Legal ( $\mathrm{p}$ $=0,048$ ) como Muito Importante. Por fim, o trabalho como Controller durante 16 a 20 anos apresentou correlação estatística com as classificações das competências de Relacionamento Externo ( $p=0,028)$ e Trabalho em Equipe $(p=0,025)$ como Muito Importante.

Ante o exposto, e de acordo com a segmentação proposta por Cardoso et al (2010), entre competências técnicas, comportamentais ou de postura, é possível depreender que: (1) Respondentes com 06 a 10 anos de carreira como Controller apresentaram correlação com uma competência técnica (Conhecimento Legal) e uma competência de postura 
(Empreendedorismo), ou seja, não se verificou correlação com competência comportamental; (2) Respondentes com 11 a 15 anos de carreira como Controller apresentaram correlação com uma competência técnica (Conhecimento Legal) e uma competência comportamental (Auto Controle), ou seja, sem correlação com competências de postura; e por fim (3) respondentes com 16 a 20 anos de carreira como Controller apresentaram correlação com duas competências comportamentais (Relacionamento Externo e Trabalho em Equipe). Desta maneira, é possível ponderar que competências comportamentais são indicadas como mais importantes pelos respondentes com mais anos de carreira como Controller (com 11 a 15 anos e com 16 a 20 anos de carreira). E que os profissionais mais experientes, com 16 a 20 anos de carreira como Controller, não enfatizaram as competências técnicas, algo realizado pelos dois outros grupos.

Na medida em que se relaciona competência com sua forma de aquisição, se faz necessário analisar mais profundamente quais são as vivências e experiências mais importantes, na visão dos respondentes, neste processo. O Gráfico 8 traz esse panorama. A $1^{\mathrm{a}}$ vivência seria a mais importante e a $5^{\mathrm{a}}$ vivência a menos importante para o desempenho do trabalho como Controller.

Gráfico 8: Vivências por ordem de importância

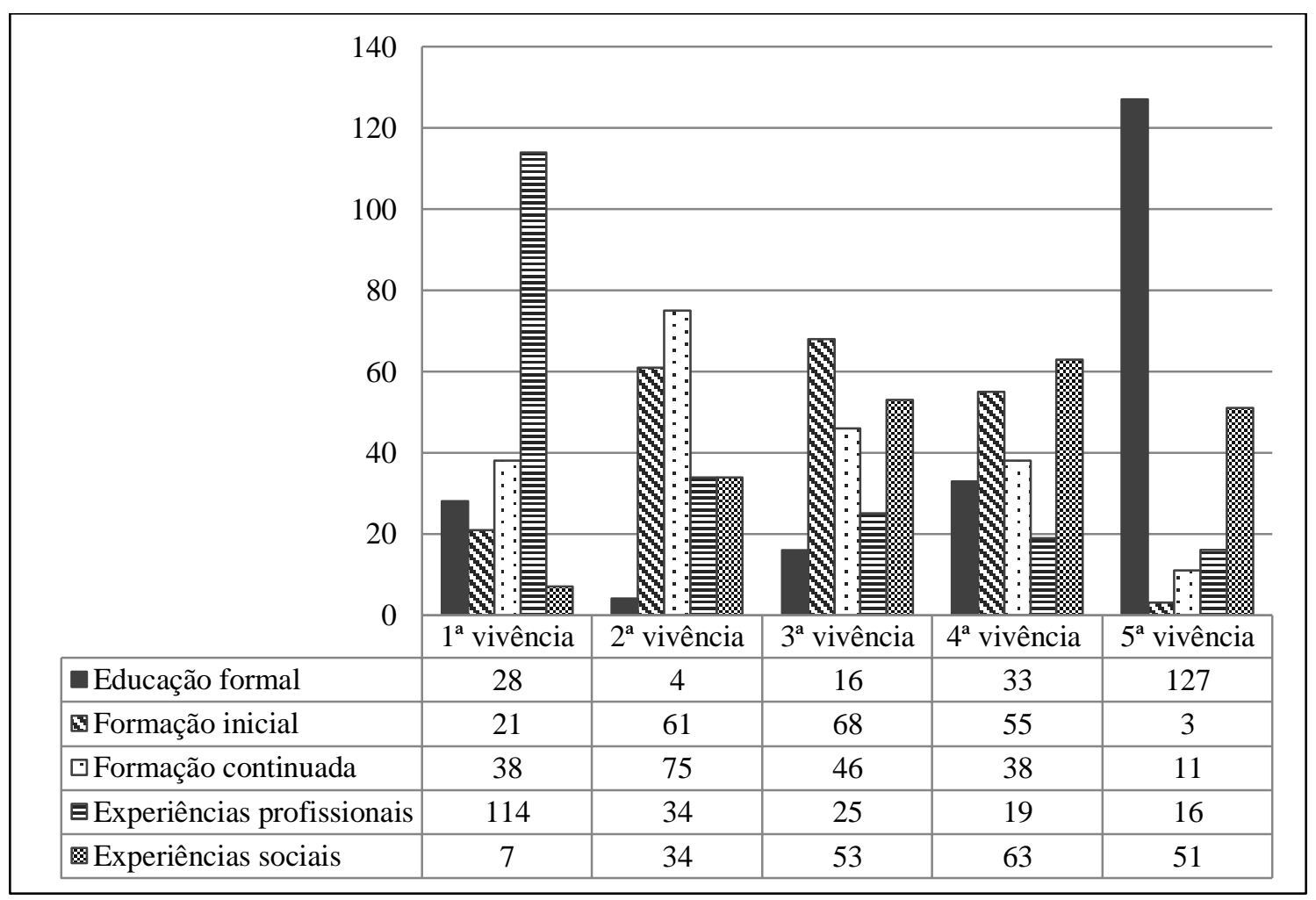

Fonte: Dados da pesquisa, 2015. 
De antemão, é possível perceber que nas duas extremidades do Gráfico $8,1^{\text {a }}$ vivência e $5^{\text {a }}$ vivência, estão as maiores concentrações de respostas em uma só experiência. Como primeira e mais importante vivência, 56,8\% dos respondentes $(\mathrm{n}=114)$ indicaram a experiência profissional. Na outra extremidade, como quinta e menos importante vivência para $61,1 \%$ dos respondentes $(n=127)$, figura a educação formal.

Com relação às vivências intermediárias, da segunda a quarta, é possível verificar visualmente que a distribuição das respostas foi mais uniforme. Como segunda vivência os respondentes indicaram a formação continuada com $36,1 \%(n=75)$, como terceira vivência a formação inicial com 32,7\% $(n=68)$ e como quarta vivência as experiências sociais com $30,3 \%(\mathrm{n}=63)$.

Com base nas duas últimas análises, das competências e vivências em grau de importância, é possível abrir uma importante discussão. Das cinco competências citadas como indispensáveis pelos respondentes, três estão relacionadas com aspectos técnicos, desenvolvidos, em regra, através de educação formal e formação inicial ou contínua. No entanto, para estes mesmos respondentes, as experiência mais valiosa é a experiência profissional.

Em uma análise superficial, estes resultados podem parecer antagônicos. Porém, se for levada em consideração a premissa da escola francesa (Le Boterf, 2003 e Zarifian, 2001) sobre o desenvolvimento de competências, que estas são validadas na ação, a experiência profissional carrega consigo uma importância diferenciada no atual contexto do trabalho. $\mathrm{Ou}$ seja, não há necessariamente incompatibilidade nessas respostas. O recente trabalho de Van Buuren e Edelenbos (2013) ajuda a corroborar esta ideia, quando explica que abordagens de aprendizado voltadas para a prática são mais eficientes no desenvolvimento de competências específicas de uma situação.

Buscando fazer uma análise mais aprofundada dessas experiências profissionais, foi solicitado aos respondentes que relacionassem as áreas em que eles atuaram profissionalmente com o nível hierárquico do cargo. A Tabela 7 traz esses resultados.

A área destacada na Tabela 7 demonstra onde foi a maior concentração de respostas. É possível concluir que as áreas de atuação profissionais, independente do nível do cargo, mais relevantes foram: Controladoria $(n=203)$; Contabilidade gerencial $(n=200)$; Financeiro $(n=$ 192); Custos $(\mathrm{n}=192)$ e Contabilidade financeira $(\mathrm{n}=187)$. Isto representa $51,9 \%$ das respostas. 
Tabela 7: Experiências profissionais

\begin{tabular}{l|c|c|c|c|c|c|c|c|c|c}
\hline \multirow{2}{*}{$\begin{array}{l}\text { Área de } \\
\text { atuação }\end{array}$} & \multicolumn{2}{|c|}{ Estágio } & \multicolumn{2}{|c|}{ Trainee } & \multicolumn{2}{c|}{ Operacional } & \multicolumn{2}{c|}{ Gerencial } & \multicolumn{2}{c}{ Não se aplica } \\
\cline { 2 - 13 } & $\mathbf{n}$ & $\mathbf{\%}$ & $\mathbf{n}$ & $\mathbf{\%}$ & $\mathbf{n}$ & $\mathbf{\%}$ & $\mathbf{n}$ & $\mathbf{\%}$ & $\mathbf{n}$ & $\mathbf{\%}$ \\
\hline Auditoria & 06 & $0,3 \%$ & 18 & $1,0 \%$ & 93 & $5,0 \%$ & 39 & $2,1 \%$ & 52 & $2,8 \%$ \\
\hline $\begin{array}{l}\text { Contabilidade } \\
\text { financeira }\end{array}$ & 07 & $0,4 \%$ & 06 & $0,3 \%$ & 100 & $5,3 \%$ & 74 & $4,0 \%$ & 21 & $1,1 \%$ \\
\hline $\begin{array}{l}\text { Contabilidade } \\
\text { gerencial }\end{array}$ & 01 & $0,1 \%$ & 03 & $0,2 \%$ & 74 & $4,0 \%$ & 122 & $6,5 \%$ & 08 & $0,4 \%$ \\
\hline Controladoria & 02 & $0,1 \%$ & 02 & $0,1 \%$ & 47 & $2,5 \%$ & 152 & $8,1 \%$ & 05 & $0,3 \%$ \\
\hline Custos & 08 & $0,4 \%$ & 06 & $0,3 \%$ & 122 & $6,5 \%$ & 54 & $2,9 \%$ & 18 & $1,0 \%$ \\
\hline Financeiro & 11 & $0,6 \%$ & 08 & $0,4 \%$ & 93 & $5,0 \%$ & 80 & $4,3 \%$ & 16 & $0,9 \%$ \\
\hline Produção & 06 & $0,3 \%$ & 12 & $0,6 \%$ & 68 & $3,6 \%$ & 18 & $1,0 \%$ & 104 & $5,6 \%$ \\
\hline $\begin{array}{l}\text { Sistemas de } \\
\text { informação }\end{array}$ & 07 & $0,4 \%$ & 19 & $1,0 \%$ & 71 & $3,8 \%$ & 55 & $2,9 \%$ & 56 & $3,0 \%$ \\
\hline Tributário & 02 & $0,1 \%$ & 12 & $0,6 \%$ & 92 & $4,9 \%$ & 62 & $3,3 \%$ & 40 & $2,1 \%$ \\
\hline Total & $\mathbf{5 0}$ & $\mathbf{2 , 7 \%}$ & $\mathbf{8 6}$ & $\mathbf{4 , 6 \%}$ & $\mathbf{7 6 0}$ & $\mathbf{4 0 , 6 \%}$ & $\mathbf{6 5 6}$ & $\mathbf{3 5 , 0 \%}$ & $\mathbf{3 2 0}$ & $\mathbf{1 7 , 1 \%}$ \\
\hline
\end{tabular}

Fonte: Dados da pesquisa, 2015.

Com relação ao cargo, os respondentes indicaram que as experiências mais valiosas foram nos níveis operacional (40,6\%) e gerencial $(35,0 \%)$.

No nível operacional, as áreas de atuação mais indicadas pelos respondentes foram a de Custos $(\mathrm{n}=122)$ e de Contabilidade financeira $(\mathrm{n}=100)$. Este resultado está alinhado com o que ensinam Anderson (1944) e Machado et al. (2010), quanto à Controladoria ter sua origem na contabilidade e manter estas raízes. Principalmente se forem levadas em consideração as atividades executadas em nível operacional.

No nível gerencial, a contabilidade continua sendo bem indicada pelos respondentes. As áreas de atuação mais citadas foram a própria Controladoria $(n=152)$ e a Contabilidade gerencial $(n=122)$.

Outro aspecto importante a ser aprofundado refere-se às disciplinas mais importantes para os Controllers, visto a relação direta com a formação acadêmica destes. Conforme a Tabela 8, os cinco conteúdos mais importantes para os respondentes foram: Contabilidade $(17,4 \%)$, Finanças $(14,0 \%)$, Custos $(12,8 \%)$, Planejamento estratégico $(11,2 \%)$ e Orçamento $(9,9 \%)$.

Em certa medida, essas disciplinas estão alinhadas com as experiências profissionais indicadas pelos respondentes na análise da Tabela 7, visto que aquelas consideradas como mais importantes dão o suporte necessário para as áreas de atuação mais citadas. 
Tabela 8: Disciplinas mais importantes para os Controllers

\begin{tabular}{l|r|r}
\hline \multicolumn{1}{c|}{ Disciplinas } & \multicolumn{1}{c|}{ N } & \multicolumn{1}{c}{ \% } \\
\hline Contabilidade & 181 & $17,4 \%$ \\
\hline Finanças & 146 & $14,0 \%$ \\
\hline Custos & 133 & $12,8 \%$ \\
\hline Planejamento estratégico & 116 & $11,2 \%$ \\
\hline Orçamento & 103 & $9,9 \%$ \\
\hline Língua estrangeira & 89 & $8,6 \%$ \\
\hline Gestão de pessoas & 84 & $8,1 \%$ \\
\hline Auditoria & 70 & $6,7 \%$ \\
\hline Tributos & 63 & $6,1 \%$ \\
\hline Sistemas de informação & 35 & $3,4 \%$ \\
\hline Direito & 11 & $1,1 \%$ \\
\hline Gestão da produção & 08 & $0,8 \%$ \\
\hline Logística & 01 & $0,1 \%$ \\
\hline Total & $\mathbf{1 0 4 0}$ & $\mathbf{1 0 0 , 0 \%}$ \\
\hline
\end{tabular}

Fonte: Dados da pesquisa, 2015.

Diante do exposto, constata-se que os Controllers avaliam que as competências indispensáveis para sua atuação profissional são: Capacidade analítica, Contabilidade e finanças, Planejamento, Trabalho em equipe e Visão estratégica. Ademais, que a vivência mais importante para o desenvolvimento de competências para sua atuação é a experiência profissional.

\subsection{TRAJETÓRIAS ACADÊMICA E PROFISSIONAL DOS CONTROLLERS}

Visando uma análise sobre os aspectos da trajetória dos Controllers que podem guardar relação com sua atuação profissional atual, foram investigados dois blocos de dados: o primeiro relativo à formação e outro de experiências profissionais, abordagem alinhada com o estudo de Van Buuren e Edelenbos (2013) sobre análise de trajetórias.

No que diz respeito à formação, apurou-se aspectos relacionados aos cursos de graduação, cursos de pós-graduação e domínio de idiomas por parte dos respondentes, com características do trabalho deles no momento da coleta.

Sobre a formação graduada, a Tabela 9 apresenta a relação entre a área do curso dos Controllers e o porte das empresas onde os mesmos atuam. 
Tabela 9: Formação graduada x Porte da empresa

\begin{tabular}{l|r|r|r|r}
\hline \multirow{2}{*}{ Formação } & \multicolumn{3}{c|}{ Porte da empresa } & \multirow{2}{*}{ TOTAL } \\
\cline { 2 - 4 } & Pequeno & \multicolumn{1}{c}{ Médio } & \multicolumn{1}{c}{ Grande } & \\
\hline Ciências Contábeis & 14 & 14 & 76 & $\mathbf{1 0 4}$ \\
\hline Administração & 01 & 09 & 35 & $\mathbf{4 5}$ \\
\hline Administração; Ciências Contábeis & 01 & 07 & 12 & $\mathbf{2 0}$ \\
\hline Economia & 02 & 03 & 13 & $\mathbf{1 8}$ \\
\hline Ciências Contábeis; Economia & - & 02 & 03 & $\mathbf{0 5}$ \\
\hline Ciências Contábeis; Direito & - & 02 & 02 & $\mathbf{0 4}$ \\
\hline Engenharia Eletrônica & - & - & 02 & $\mathbf{0 2}$ \\
\hline Outros & 02 & 02 & 06 & $\mathbf{1 0}$ \\
\hline TOTAL & $\mathbf{2 0}$ & $\mathbf{3 9}$ & $\mathbf{1 4 9}$ & $\mathbf{2 0 8}$ \\
\hline
\end{tabular}

Fonte: Dados da pesquisa, 2015.

Desta tabela, chama a atenção que dos 20 respondentes que disseram trabalhar em empresas de pequeno porte, 15 (75\%) tem formação em contabilidade. Ademais, a maior parte dos graduados em Administração trabalha em empresas de grande porte. Dos 65 respondentes com formação nessa área, 55 (85\%) estão nessa condição. Para este dado, houve correlação significativa ( $p=0,022)$ entre graduação em Administração, de forma exclusiva ou combinada com outros cursos, e atuação em empresas de grande porte. Tal correlação estatística não foi observada para os demais cursos de graduação.

Analisando o trabalho de Ferreira et al (2011), que estudou os anúncios de vagas de emprego para Controllers, a informação exposta acima traz um oportuno debate. Verificou-se que a maioria das vagas (89\%) tinha como requisito para seleção a formação graduada em Contabilidade ou Contabilidade e áreas afins. Em somente 5,6\% dos casos, a graduação em Administração era diretamente citada. Ou seja, ainda é clara a predileção, para as vagas de Controllers, o profissional formado em Contabilidade, no entanto, os resultados apresentados neste estudo demonstram como o curso de Administração pode dar esse suporte necessário paro exercício da função.

Ainda em relação à formação graduada, foi observada a relação entre as áreas e os setores de atividade das empresas. Esta relação foi pensada visto que a classificação utilizada para o porte da empresa leva em consideração o número de funcionários e o setor de atividade. Foi constatada uma correlação significativa $(p=0,020)$ entre graduação em Ciências Contábeis, de forma exclusiva ou combinada com outros cursos, e atuação em empresas do setor de atividade das Indústrias. Neste aspecto, dos 133 respondentes com formação nessa área, 64 (48\%) estão nessa condição. 
No trabalho de Machado (2008), que estudou o perfil da controladoria nas 100 maiores empresas do Estado de Santa Catarina, com relação ao curso de graduação dos respondentes, $79 \%$ são formados em Ciências Contábeis, número maior, inclusive, ao desta pesquisa. Ou seja, para empresas de grande porte, é possível ponderar que o curso de contabilidade é um requisito importante.

Quanto à formação de pós-graduação, a Tabela 10 apresenta a relação entre esta e o nível hierárquico do Controller, onde: DIR = Diretoria; GER = Gerência; SUP = Supervisão; $\mathrm{OPE}=$ Operacional. A maior parte dos respondentes assinalou ter pós-graduação do tipo Lato Sensu, o que não é possível fazer nenhuma ponderação com relação ao nível hierárquico. No entanto, somente 01 dos 28 respondentes, que disseram ter pós-graduação no nível Stricto Sensu (Mestrado e/ou Doutorado), está em um nível hierárquico de supervisão. Os demais, ou são gerentes, ou são diretores das empresas que atuam. Desta maneira, apesar deste tipo de formação de pós-graduação não ser a mais comum entre os respondentes, é possível ponderar, para esta amostra, que Controllers com este nível de formação ocupam cargos hierárquicos mais altos.

Tabela 10: Formação de pós-graduação x Nível hierárquico como Controller

\begin{tabular}{l|r|r|r|r|r}
\hline \multirow{2}{*}{ Tipo de curso de pós-graduação } & \multicolumn{4}{|c|}{ Nível hierárquico como Controller } & \multirow{2}{*}{ TOTAL } \\
\cline { 2 - 5 } & \multicolumn{1}{c}{ DIR } & \multicolumn{1}{c}{ GER } & \multicolumn{1}{c}{ SUP } & \multicolumn{1}{c}{ OPE } & \\
\hline Somente MBA & 22 & 46 & 13 & - & $\mathbf{8 1}$ \\
\hline Esp. Lato Sensu e MBA & 17 & 26 & 03 & - & $\mathbf{4 6}$ \\
\hline Somente Esp. Lato Sensu & 12 & 16 & 05 & 02 & $\mathbf{3 5}$ \\
\hline Somente Mestrado & 01 & 06 & 01 & - & $\mathbf{0 8}$ \\
\hline Esp. Lato Sensu e Mestrado & 03 & 04 & - & - & $\mathbf{0 7}$ \\
\hline Esp. Lato Sensu, MBA e Mestrado & 02 & 04 & - & - & $\mathbf{0 6}$ \\
\hline MBA e Mestrado & 01 & 05 & - & - & $\mathbf{0 6}$ \\
\hline Mestrado e Doutorado & - & 01 & - & - & $\mathbf{0 1}$ \\
\hline Nenhuma & 01 & 17 & - & - & $\mathbf{1 8}$ \\
\hline TOTAL & $\mathbf{5 9}$ & $\mathbf{1 2 5}$ & $\mathbf{2 2}$ & $\mathbf{0 2}$ & $\mathbf{2 0 8}$ \\
\hline
\end{tabular}

Fonte: Dados da pesquisa, 2015.

Levando em consideração, também, as áreas de conhecimento, os estudos de correlação trouxeram o seguinte resultado: foi constatada uma correlação significativa ( $p=$ 0,043) entre cursos de pós-graduação Lato Sensu em Auditoria, de forma exclusiva ou combinada com outros cursos, e atuação com o nível hierárquico de Diretoria, uma vez que dos 08 respondentes com pós-graduação Lato Sensu em Auditoria, 05 (63\%) são diretores. 
Frezatti e Kassai (2003), em seu estudo sobre o impacto de cursos de MBA em sobre seus egressos, constatam que 58\% dos alunos apresentam evolução na carreira após a conclusão deste tipo de pós-graduação. Este trabalho não consegue mensurar se este tipo de curso é responsável por esta evolução na carreira dos respondentes, visto que nenhuma das perguntas teve este foco. No entanto, visto o grande número de respondentes com formação de pós-graduação, infere-se que este seja um requisito essencial para estes profissionais. Alinhado a esta perspectiva, o trabalho de Araújo, Callado e Cavalcanti (2014), traz que $58,4 \%$ dos alunos de um curso de especialização Lato Sensu em Controladoria classificam a motivação "Perspectiva de melhorias na carreira" como muito importante.

No que tange a relação entre a formação de pós-graduação e o porte da empresa, Tabela $11,54 \%$ do total de respondentes $(\mathrm{n}=112)$ disseram ter formação em nível Lato Sensu e/ou MBA e trabalhar em grandes empresas. Por outro lado, somente 03 dos 28 respondentes que disseram ter pós-graduação Stricto Sensu, trabalham em empresas de pequeno porte.

Tabela 11: Formação de pós-graduação x Porte da empresa

\begin{tabular}{l|r|r|r|r}
\hline \multirow{2}{*}{ Tipo de curso de pós-graduação } & \multicolumn{3}{|c|}{ Porte da empresa } & \multirow{2}{*}{ TOTAL } \\
\cline { 2 - 5 } & \multicolumn{1}{|c|}{ Pequeno } & \multicolumn{1}{|c}{ Médio } & \multicolumn{1}{c}{ Grande } & \\
\hline Somente MBA & 06 & 15 & 60 & $\mathbf{8 1}$ \\
\hline Esp. Lato Sensu e MBA & 09 & 09 & 28 & $\mathbf{4 6}$ \\
\hline Somente Esp. Lato Sensu & 02 & 09 & 24 & $\mathbf{3 5}$ \\
\hline Somente Mestrado & 02 & 01 & 05 & $\mathbf{0 8}$ \\
\hline Esp. Lato Sensu e Mestrado & - & 01 & 06 & $\mathbf{0 7}$ \\
\hline Esp. Lato Sensu, MBA e Mestrado & 01 & - & 05 & $\mathbf{0 6}$ \\
\hline MBA e Mestrado & - & - & 06 & $\mathbf{0 6}$ \\
\hline Mestrado e Doutorado & - & - & 01 & $\mathbf{0 1}$ \\
\hline Nenhuma & - & 04 & 14 & $\mathbf{1 8}$ \\
\hline TOTAL & $\mathbf{2 0}$ & $\mathbf{3 9}$ & $\mathbf{1 4 9}$ & $\mathbf{2 0 8}$ \\
\hline
\end{tabular}

Fonte: Dados da pesquisa, 2015.

Ainda dentro deste contexto, verificou-se correlação $(p=0,019)$ entre pós-graduação Lato Sensu e MBA com empresas de pequeno porte. Dos 20 respondentes que trabalham em empresas de pequeno porte, 09 (45\%) disseram ter especialização Lato Sensu e MBA.

Quanto aos idiomas, a Tabela 12 expõe a articulação entre o domínio destes com o porte das empresas onde os Controllers atuam. 
Tabela 12: Domínio de idiomas X Porte da empresa

\begin{tabular}{l|r|r|r|r}
\hline \multirow{2}{*}{ Domínio de idiomas } & \multicolumn{3}{|c|}{ Porte } & \multirow{2}{*}{ TOTAL } \\
\cline { 2 - 5 } & Pequeno & \multicolumn{1}{|c|}{ Médio } & Grande & \\
\hline Sim & 17 & 37 & 138 & $\mathbf{1 9 2}$ \\
\hline Não & 03 & 02 & 11 & $\mathbf{1 6}$ \\
\hline TOTAL & $\mathbf{2 0}$ & $\mathbf{3 9}$ & $\mathbf{1 4 9}$ & $\mathbf{2 0 8}$ \\
\hline
\end{tabular}

Fonte: Dados da pesquisa, 2015.

Analisando os dados é possível inferir que, isoladamente, o domínio de língua estrangeira não influencia no porte da empresa onde os respondentes atuam. No entanto, ainda foi possível identificar algumas correlações quanto a este aspecto: domínio do alemão com o setor de atividade indústria $(p=0,04)$, domínio do espanhol com o setor de atividade de tecnologia $(p=0,015)$ e domínio do inglês com o setor de atividade da construção civil ( $p=$ $0,027)$.

Conforme mencionado, o segundo conjunto de análises sobre as trajetórias dos Controllers diz respeito às experiências profissionais. $\mathrm{O}$ primeiro aspecto observado, em relação a isto, refere-se ao tempo de carreira profissional declarado dos respondentes. $\mathrm{O}$ gráfico 9 traz uma relação entre o tempo de carreira profissional e o nível hierárquico ocupado pelos respondentes no momento da pesquisa.

Gráfico 9: Tempo de carreira profissional X Nível Hierárquico

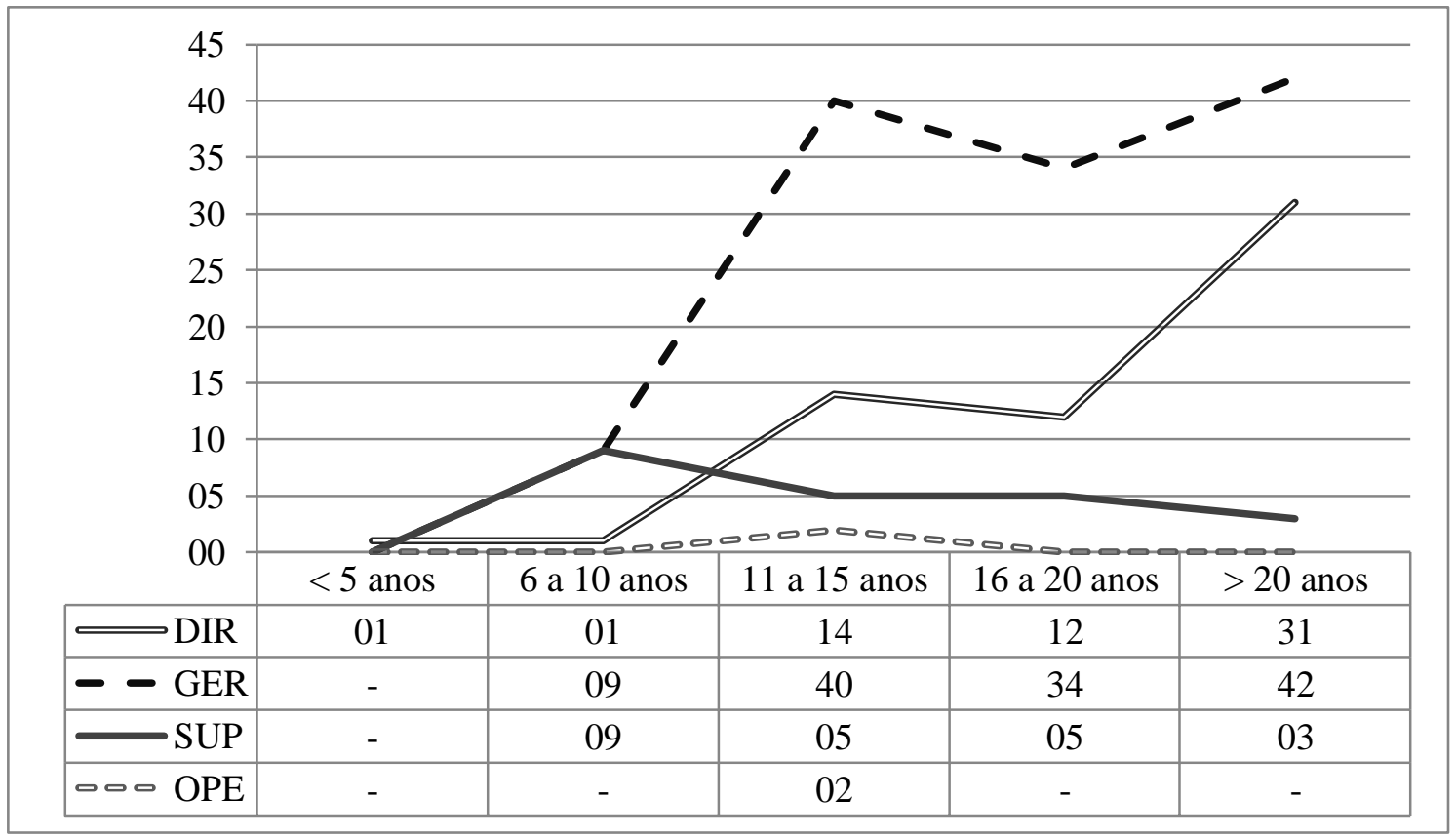

Fonte: Dados da pesquisa, 2015. 
Segundo revela o Gráfico 9, verifica-se uma tendência crescente entre o tempo de carreira e a quantidade de Controllers ocupando níveis hierárquicos mais altos dentro das empresas (diretoria e gerência), ao passo em que o inverso acontece no nível de supervisão. Desta maneira, corrobora-se a ideia de que o cargo de Controller guarda relação com os níveis de gestão das empresas.

Complementando esta informação, verificou-se que 09 dos 22 respondentes que disseram estar em um nível hierárquico de supervisão, têm de 06 a 10 anos de carreira profissional como Controller, sendo possível constatar uma correlação estatisticamente significativa $(p=0,002)$ nesta análise. Ou seja, a correlação demonstra que profissionais em início de carreira na área de Controladoria ocupam níveis hierárquicos mais baixos dentro das empresas.

Ainda no universo das informações referentes à atuação profissional, o Gráfico 10 traz as áreas onde as experiências foram consideradas as mais relevantes para o desempenho de sua função como Controller.

A maioria dos respondentes, 34\% $(n=60)$ assinalou que a experiência no setor de Controladoria foi a mais relevante, seguida da Contabilidade Financeira, com 20\% ( $\mathrm{n}=35)$. Estas duas experiências estão dentro das mais assinaladas conforme exposto na Tabela 7 , sobre as experiências profissionais dos Controllers. Dos 208 respondentes, 09 não indicaram a experiência profissional mais relevante.

Gráfico 10: Experiência profissional mais relevante

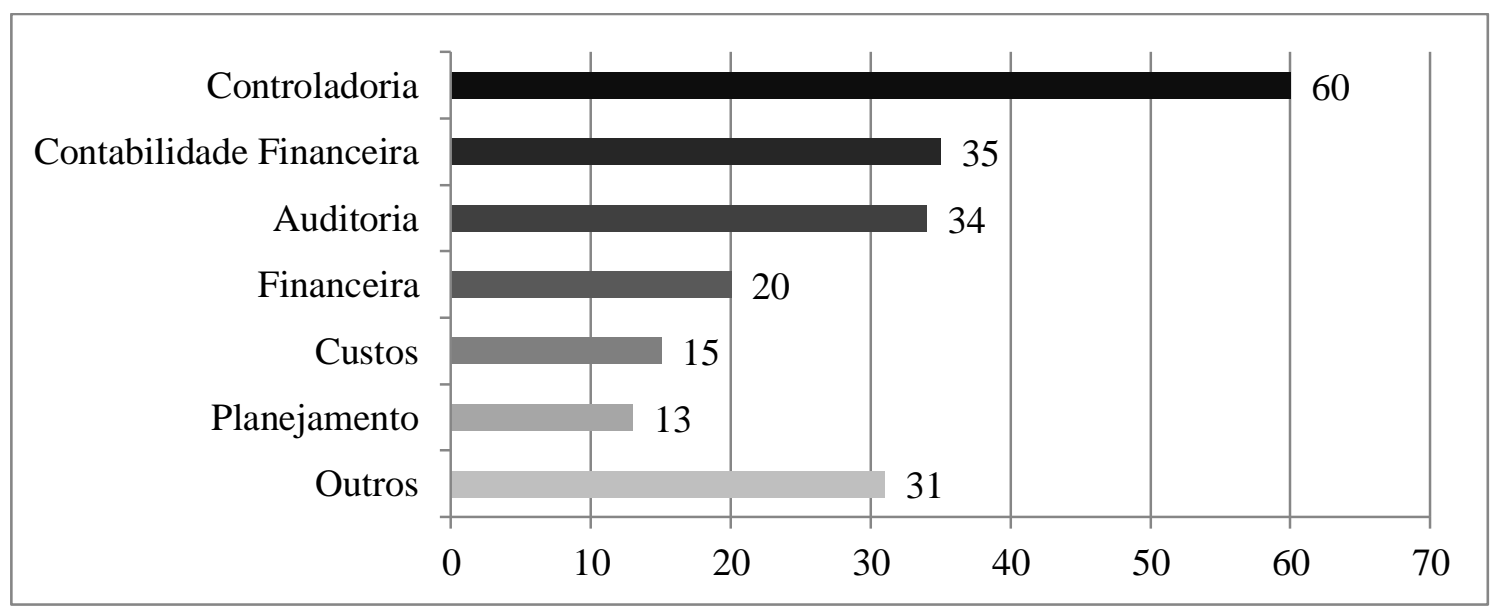

Fonte: Dados da pesquisa, 2015.

Uma resposta interessante nessa questão foi a experiência em Auditoria, assinalada como a mais relevante por $19 \%$ respondentes $(n=34)$. Contudo, ela não faz parte do rol das 
cinco experiências profissionais mais assinaladas pelos Controllers, conforme já discutido a partir da Tabela 7. Este resultado indica que, apesar da Auditoria não ser uma experiência de base para a maioria dos profissionais de Controladoria, ela é muito valiosa para aqueles auditores que se tornaram Controllers.

Ainda com relação à Auditoria como experiência profissional mais relevante, verificou-se uma correlação ( $p=0,007)$ entre esta e a atuação do respondente em empresas de pequeno porte. Desta maneira, é possível concluir que, com relação aos respondentes desta pesquisa, os profissionais com experiência mais valiosa em Auditoria estão alocados em empresas de pequeno porte. Não foi constatada, para nenhuma outra experiência, este tipo de correlação.

Já a Tabela 13 relaciona a experiência mais relevante com nível hierárquico dos respondentes.

Cabe destacar que dos 20 respondentes que disseram que a experiência na área Financeira foi a mais importante, 10 estão ocupando cargo de Diretoria e 09 de Gerência. Para este dado, houve correlação significativa $(p=0,035)$ entre experiência profissional mais valiosa na área Financeira e nível hierárquico de Diretoria. Além disso, verificou-se que dos 34 respondentes que assinalaram que a experiência em Auditoria foi a mais relevante, 79\% (n $=27$ ) deles estão no nível de Gerência. Neste caso, houve correlação significativa $(p=0,013)$ entre experiência profissional mais valiosa Auditoria e nível hierárquico de Gerência.

Tabela 13: Experiência profissional mais valiosa X Nível hierárquico

\begin{tabular}{l|r|r|r|r|r}
\hline \multirow{2}{*}{$\begin{array}{l}\text { Experiência profissional } \\
\text { mais valiosa }\end{array}$} & \multicolumn{4}{|c|}{ Nível hierárquico como Controller } & \multirow{2}{*}{ TOTAL } \\
\cline { 2 - 6 } & \multicolumn{1}{c}{ DIR } & \multicolumn{1}{c}{ GER } & \multicolumn{1}{c}{ SUP } & \multicolumn{1}{c}{ OPE } & \\
\hline Controladoria & 20 & 31 & 08 & 01 & $\mathbf{6 0}$ \\
\hline Contabilidade Financeira & 06 & 24 & 04 & 01 & $\mathbf{3 5}$ \\
\hline Auditoria & 05 & 27 & 02 & - & $\mathbf{3 4}$ \\
\hline Financeira & 10 & 09 & 01 & - & $\mathbf{2 0}$ \\
\hline Custos & 04 & 08 & 03 & - & $\mathbf{1 5}$ \\
\hline Planejamento & 04 & 08 & 01 & - & $\mathbf{1 3}$ \\
\hline Outros & 07 & 13 & 02 & - & $\mathbf{2 2}$ \\
\hline TOTAL & $\mathbf{5 6}$ & $\mathbf{1 2 0}$ & $\mathbf{2 1}$ & $\mathbf{0 2}$ & $\mathbf{1 9 9}$ \\
\hline
\end{tabular}

Fonte: Dados da pesquisa, 2015.

Diante dos dados, verifica-se, de fato, que a maioria dos Controllers são graduados em Contabilidade e, também, tem como experiências mais relevantes a atuação nas áreas de Contabilidade e Controladoria. Entretanto, ter considerado como áreas da experiência 
profissional mais importante para o desempenho de sua função a Auditoria e a Financeira, apesar de menos respondentes, parecem fazer mais diferença na ocupação de cargos de níveis mais altos, visto as correlações estatísticas apresentadas. 


\section{CONSIDERAÇÕES FINAIS}

O objetivo desta pesquisa foi investigar os aspectos da trajetória do Controller e sua contribuição para o desenvolvimento de competências e atuação profissional. Ou seja, já que toda pessoa é o resultado de suas vivências passadas e atuais, de que forma a trajetória de um Controller se relaciona com suas competências e a sua atuação. Para atingir este objetivo, a pesquisa se valeu de um questionário respondido por 208 Controllers.

Os principais resultados obtidos podem ser sistematizados em três pontos: com relação ao perfil do Controller, quanto às experiências que contribuem para as competências essenciais e, por fim, da relação entre trajetória acadêmica e profissional e a atuação desses profissionais.

Primeiro, no que se refere ao perfil do Controller, trata-se de profissionais, em sua maioria, do sexo masculino, com graduação ligada à área de Contabilidade e Administração, com formação de pós-graduação predominantemente em curso Lato Sensu e com domínio de língua estrangeira. Ademais, são profissionais em sua maioria com mais de 20 anos de carreira, ocupando cargos de gerência, de forma predominante em indústrias da região Sudeste.

O segundo ponto observado diz respeito às experiências que contribuíram para o desenvolvimento das competências essenciais para a atuação profissional do Controller. Os respondentes apontaram como competências indispensáveis para o seu trabalho a capacidade analítica, domínio de contabilidade e finanças, planejamento, trabalho em equipe e visão estratégica. Como principal vivência para o desenvolvimento das competências necessárias, estes Controllers indicaram as experiências profissionais.

O terceiro tópico de resultados trata da relação entre trajetória acadêmica e profissional e a atuação dos Controllers. Segundo a análise, ainda predomina, para as vagas de Controller, profissionais formados em Contabilidade. No entanto, verificou-se correlação significativa entre os profissionais formados em Administração e a atuação em empresas de grande porte. Desta maneira, pondera-se a importância deste curso para o exercício da função de Controller. Com relação ao tipo de pós-graduação, apesar da maioria dos respondentes terem formação Lato Sensu, aqueles que concluíram cursos do tipo Stricto Sensu ocupam cargos de níveis hierárquicos mais altos nas empresas que atuam.

Ainda, no que diz respeito à trajetória profissional, observou-se uma tendência crescente entre o tempo de carreira e a quantidade de Controllers ocupando níveis hierárquicos mais elevados nas empresas. Outrossim, a experiência profissional em 
Controladoria foi considerada a mais importante para a maioria dos Controllers e, além disso, foram verificadas correlações entre a experiência em Auditoria e a atuação em empresas de pequeno porte e em níveis hierárquicos de gerência.

Ante o exposto, pode se concluir que vivências acadêmicas e profissionais, de naturezas diversas, podem contribuir de forma incisiva para o desenvolvimento das competências essenciais as suas atividades. Ademais, verifica-se que para chegarem a este cargo, os profissionais devem valorizar um conjunto de experiências, tais como cursos de pósgraduação bem avaliados academicamente e atuação em áreas, para além da contabilidade, como de auditoria e finanças.

Como limitações do estudo pontua-se a forma de acesso aos profissionais. A ausência de um ponto de partida que pudesse subsidiar o contato com os Controllers, como uma instituição representativa da categoria, dificultou um mapeamento mais amplo dos profissionais em atuação no país. Outra limitação decorre da natureza do instrumento utilizado na coleta dos dados para a pesquisa, que restringe o aprofundamento dos dados. Entretanto, cabe ressaltar que o levantamento realizado requer este tipo de questionário de forma estruturada.

Para estudos futuros sugere-se uma investigação mais detalhada das vivências e suas particularidades, e de como estas podem contribuir para o desenvolvimento das competências necessárias para atuação do Controller. Outra possibilidade seria analisar aspectos distintos dos verificados nesta pesquisa, tais como remuneração, rotina de estudo individual e estrutura administrativa das empresas, de modo a entender a relação entre as experiências vividas em sua trajetória e o contexto no qual ele se insere.

Entende-se como contribuição desta pesquisa, para o âmbito acadêmico, uma análise mais ampla que a identificação de competências essenciais para o trabalho do Controller, contemplando uma proposta de se estudar o desenvolvimento destas. Além disso, pode auxiliar na formatação de currículos acadêmicos mais articulados com a prática do profissional de Controladoria. E como contribuição para o meio profissional, esta pesquisa serve como um diagnóstico da função de Controller e dos aspectos da trajetória que contribuem para se chegar a este cargo. 


\section{REFERÊNCIAS}

ALMEIDA, Lauro Brito de, PARISI, Claudio; PEREIRA, Carlos Alberto. Controladoria. In: CATELLI, Armando. Controladoria: Uma Abordagem da Gestão Econômica - GECON. 2.ed. São Paulo: Atlas, 2001.

ANDERSON, D. R. The Function of Industrial controllership. The Accounting Review. v. 19, n. 1, p. 55-65, 1944.

ARAUJO, Antônio de Pádua. Competências profissionais e educação corporativa em gestão de pessoas: um estudo empírico. Tese (Doutorado) - Universidade de São Paulo, São Paulo, São Paulo, Brasil, 2011.

ARAÚJO, Jaqueline Gomes Rodrigues; CALLADO, Aldo Leonardo Cunha; CAVALCANTI, Brasiliana Sulamita B. Habilidades e Competências do controller: Um Estudo com Alunos de Cursos de Pós-graduação em Controladoria. Revista Catarinense da Ciência Contábil, v. 13, n. 38, p.52-64, 2014.

BELFIORE, Patrícia. Estatística Aplicada a Administração, Contabilidade e Economia Com Excel e SPSS. Rio de Janeiro: Elsevier, 2015.

BEUREN, Ilse Maria. O papel da controladoria no processo de gestão. In: SCHMIDT, Paulo (Org). Controladoria: agregando valor para a empresa. Porto Alegre: Bookman/Artmed, 2002.

BORINELLI, Márcio. Estrutura Conceitual Básica de Controladoria: sistematização à luz da teoria e da práxis. 2006. 341 f. Tese (Doutorado em Contabilidade) - Departamento de Contabilidade e Atuária da Faculdade de Economia, Administração e Contabilidade, Universidade de São Paulo, São Paulo, 2006.

BOYATZIS, Richard E. The competent manager: a model for effective performance. New York: John Wiley \& Sons, 1982.

BOYATZIS, Richard E. Competencies in the 21st century. Journal of Management Development. v. 27, n. 1, p. 34-50, 2008.

BOYATZIS, Richard E; SAATCIOGLU, Argun. A 20-year view of trying to develop emotional, social and cognitive intelligence competencies in graduate management education. Journal of Management Development. v. 27, n. 1, p. 92-108, 2008.

BRANDÃO, Hugo Pena. Aprendizagem, contexto, competência e desempenho: um estudo multinível. Tese de doutorado, Instituto de Psicologia, Universidade de Brasília, Brasília, DF, Brasil, 2009.

CALIJURI, Mônica Sionara Schpallir. controller - O perfil atual e a necessidade do mercado de trabalho, Revista Brasileira de Contabilidade, n. 150, pp. 38-53. 2004. 
CARDOSO, Ricardo Lopes. Competências do contador: um estudo empírico. Tese (Doutorado em Ciências Contábeis). Universidade de São Paulo - USP. São Paulo, 2006.

CARDOSO, Ricardo Lopes et al. Entendo e explorando as competências do contador gerencial: uma análise feita pelos profissionais. Revista ASAA - Advances in Scientific and Applied Accounting, v. 3, n.3, p. 353-371, 2010.

CNE. Resolução CNE/CES no 1, de 3 de abril de 2001. Diário Oficial da União, Poder Executivo, Brasília, DF, 9 de abril de 2001, seção 1, p. 12.

COELHO, Eduardo; LUNKES, Rogério João; MACHADO, Alessandra de Oliveira. A controladoria na hierarquia organizacional: um estudo nas maiores empresas do estado de Santa Catarina. Enfoque: Reflexão Contábil. v. 31, n. 2, p. 33-46, 2012.

DAL VASCO, Delci; DANIEL, Maia Marilde; TARIFA, Marcelo Resquetti. Estudo do Perfil, Conhecimento, Papel e Atuação do controller em Cooperativas. Revista de Finanças Aplicadas. V. 2, p.1-31, 2014.

DURAND, Thomas. L'alchimie de la compétence. Revue Française de Gestion, n. 127, p. 261-292, 2000.

DUTRA, Joel Souza. Competências: Conceitos e Instrumentos para a Gestão de Pessoas na Empresa Moderna. São Paulo: Atlas, 2004.

FERRARI, Mara Juliana et al. O perfil do controller sob a ótica do mercado de trabalho brasileiro. RIC - Revista de Informação Contábil, v.7, n.3, p.25-50, 2013.

FERREIRA, Celma Duque. O perfil profissional do Controller e as funções de Controladoria: um estudo da atual necessidade do mercado de trabalho. Pernambuco, PE: 2011. Dissertação (Mestrado em Ciências Contábeis), Universidade Federal de Pernambuco, 2011.

FERREIRA, Celma Duque et al. O Perfil Profissional do Controller e as Funções de Controladoria: Um Estudo da Atual Necessidade do Mercado de Trabalho. Global Journal of Management and Business Research, v. 14, n. 1, p. 45-58, 2014.

FIGUEIREDO, Sandra; CAGGIANO, Paulo Cesar. Controladoria: teoria e prática. 3 ed. São Paulo: Atlas, 2004.

FLEURY, Afonso; FLEURY, Maria Tereza Leme. Estratégias Empresariais e Formação de Competências: Um Quebra-cabeça Caleidoscópico da Indústria Brasileira. 3. Ed. São Paulo: Atlas, 2007.

FLEURY, Maria Tereza Leme; FLEURY, Afonso. Construindo o conceito de competência. Revista de Administração Contemporânea. v.5, n.spe, p. 183-196, 2001.

FREZATTI, Fábio; KASSAI, Silvia. Estudo do impacto de um curso MBA em Controladoria na evolução de seus egressos. Revista Contabilidade \& Finanças, São Paulo, Ed. Comemorativa, p. 54-65, out. 2003. 
GOMES, Carolina Valentim; SOUZA, Paula de; LUNKES, Rogério João. O perfil do profissional da controladoria solicitado por empresas brasileiras. GCG: Revista de Globalización, Competitividad \& Gobernabilidad, v. 08, n. 01, p. 34-50, 2014.

GÜNTER, Hartmut. Como elaborar um questionário (Série: Planejamento de Pesquisa nas Ciências Sociais, $N^{o}$ 01). Brasília, DF: UnB, 2003. Disponível em: http://www.psiambiental.net/pdf/01Questionario.pdf. Acesso em 16 de Janeiro de 2015.

HAIR, Joseph et al. Análise Multivariada de Dados. 6. Ed. Porto Alegre: Bookman, 2006.

LE BOTERF, Gui. Desenvolvendo a competência dos profissionais. Porto Alegre: Artmed Editora, 2003.

LEONARD; David C. The impact of learning goals on emotional, social, and cognitive intelligence competency development. Journal of Management Development. v. 27, n. 1, p. 109-128, 2008.

LUNKES, Rogério João; SCHNORRENBERGER, Darci. Controladoria: na coordenação dos sistemas de gestão. São Paulo: Atlas, 2009.

LUNKES, Rogério João et al. Análise da legitimidade sociopolítica e cognitiva da controladoria no Brasil. Revista Contabilidade \& Finanças da Universidade de São Paulo. São Paulo, v. 23, p. 89-101, 2012.

LUNKES, Rogério João; SCHNORRENBERGER, Darci; GASPARETTO, Valdirene; VICENTER, Ernesto Fernando Rodrigues. Considerações sobre as funções da controladoria nos Estados Unidos, Alemanha e Brasil. Universo Contábil, v. 5, n. 4, p. 63-75, 2009.

LUNKES, Rogério João; SCHNORRENBERGER, Darci; ROSA, Fabricia Silva da. Funções da Controladoria: uma análise no cenário brasileiro. Revista Brasileira de Gestão de Negócios, v. 15, n. 47, p. 283-289, 2013.

MACHADO, Alessandra de Oliveira. Um estudo sobre o perfil da controladoria nas 100 maiores empresas do Estado de Santa Catarina. Florianópolis: Dissertação do Programa de Pós-Graduação em Contabilidade da Universidade Federal de Santa Catarina, 2008.

MACHADO, Alessandra de Oliveira et al. Competências do controller: um estudo nas 100 maiores empresas de Santa Catarina. Pensar Contábil, v.12, n.47 p. 26-34, 2010.

MACHADO, Vinicius Sucupira de Alencar; CASA NOVA, Silvia Pereira de Castro. Análise comparativa entre os Conhecimentos Desenvolvidos no curso de Graduação em Contabilidade e o Perfil do Contador Exigido pelo Mercado de Trabalho: uma pesquisa de campo sobre Educação Contábil. Revista de Educação e Pesquisa em Contabilidade, v. 2, n.1, p. 1-28, 2007.

MACIEL, Lucas Fernandes; LIMA, Robernei Aparecido. O perfil ideal do controller nas condições que se apresentam o mercado de trabalho no Brasil. Disponível em: <http://www.inicepg.univap.br/cd/INIC_2011/anais/arquivos/0485_0402_01.pdf >. Acesso em 20 de novembro de 2014. 
MARTINS, Vinícius Gomes et al. A utilização de modelos de avaliação de desempenho Sob a perspectiva do GECON e do Balanced Scorecard: Estudo de caso em uma central de cooperativas de crédito. Revista Evidenciação Contábil \& Finanças, v. 1, n.1, p. 99-117, 2013.

McCLELLAND, David. C. Testing for competence rather than for intelligence. American Psychologist, n. 28, p. 1-4, 1973.

MIRANDA, Cláudio de Souza. Ensino em contabilidade gerencial: uma análise comparativa de percepções de importância entre docentes e profissionais, utilizando as dimensões de atividades, artefatos e competências. 2010. Tese (Doutorado em Ciências Contábeis), Programa de Pós-Graduação em Ciências Contábeis, Departamento de Contabilidade da Faculdade de Economia, Administração e Contabilidade da Universidade de São Paulo. 2010.

MOSIMANN, Clara Pellegrinello; FISCH, Silvio. Controladoria: Seu papel na administração de empresas. São Paulo: Atlas, 1999.

NASCIMENTO, Auster Moreira; BIANCHI, Marcia. Um estudo sobre o papel da controladoria no processo de redução de conflito de agência e de Governança Corporativa. In: CONGRESSO USP DE CONTABILIDADE E CONTROLADORIA, 5., 2005, São Paulo. Anais... São Paulo: FEA/USP, 2005.

ORO, Ieda Margarete et al. Perfil do Profissional de Controladoria sob a Óptica do Mercado de Trabalho Brasileiro. Pensar Contábil, v. 11, n. 44, p. 5- 15, 2009.

PELEIAS, Ivam Ricardo et al. Evolução do ensino da contabilidade no Brasil: uma análise histórica. Revista Contabilidade e Finanças, Universidade de São Paulo/USP, São Paulo, Edição 30 Anos de Doutorado, p. 19 -32, jun. 2007.

PERRENOUD, Philippe. Construir as competências desde a escola. Porto Alegre: Artmed, 1999.

PINNINGTON, Ashly H. Competence development and career advancement in professional service firms. Personnel Review, v. 40, n. 4, p. 443-465, 2011.

RICHARTZ, Fernando. et al. Análise Curricular em Controladoria e as Funções do Controller. Revista Iberoamericana de Contabilidad de Gestión. v. 9, n. 19, p. 25-39, 2012.

RUAS, Roberto. Gestão por competências: uma contribuição à estratégia das organizações. In: RUAS, Roberto; ANTONELLO, Claudia Simone; BOFF, Luiz Henrique. (Orgs.). Aprendizagem organizacional e competências. Porto Alegre: Bookman, 2005.

SIQUEIRA, José Ricardo Maia de; SOLTELINHO, Wagner. O Profissional de Controladoria no Mercado Brasileiro - Do Surgimento da Profissão aos Dias Atuais. Revista Contabilidade \& Finanças FIPECAFI - FEA - USP, v.16, n.27, p.66-77, 2001. 
SOUZA, Bruno Carlos de; BORINELLI, Márcio Luiz. As funções de controladoria: um estudo a luz dos anúncios da empresas de recrutamento de profissionais. In: Congresso Brasileiro de Custos, 2009, Fortaleza/CE. Anais. XVI Congresso Brasileiro de Custos, 2009.

VAN BUUREN, Arwin; EDELENBOS, Jurian. Organizational competence development in two public agencies in the Netherlands: the effectiveness of in-company training versus learning by doing. Public Personnel Management, v.42, n.3, p. 385-399, 2013.

VARGAS, Alzenir José de; BEUREN, Ilse Maria. O envolvimento do controller no processo de gestão: um estudo em empresas brasileiras. Advances in Scientific and Applied Accounting, v.5, n.3, p. 405-426, 2012.

WEBER, Jürgen. The development of controller tasks: Explaining the nature of controllership and its changes, Journal of Management Control, v.22, n. 1, p. 25 -46, 2011.

WHEELER, Jane V. The impact of social environments on emotional, social, and cognitive competency development. Journal of Management Development. v. 27, n. 1, p. 129-145, 2008.

ZARIFIAN, Philippe. Objetivo Competência: Por Uma Nova Lógica. São Paulo: Artmed Atlas, 2001, p.197.

ZONI, Laura; KENNETH, Merchant. controller involvement in management: an empirical study in large Italian corporations. Journal of Accounting \& Organizational Change, v. 3, n.1, p. 29-42, 2007. 


\section{APÊNDICE - Questionário aplicado}

\section{Pesquisa Acadêmica - Trajetória do Controller}

Prezado (a), estamos desenvolvendo uma pesquisa de âmbito nacional, vinculada ao Programa Multi-Institucional e Inter-regional de Pós-Graduação em Ciências Contábeis UnB, UFPB e UFRN, sobre experiências profissionais e acadêmicas que contribuem para a formação de um Controller.

Este questionário está dividido em 03 (três) blocos de perguntas. No Bloco 01, o foco são as competências relacionadas com a função de Controller. O Bloco 02 contempla questões acerca das experiências essenciais no desenvolvimento de um profissional de controladoria. Por fim, no Bloco 03, o perfil do respondente. O tempo médio de resposta do questionário é de 10 minutos.

Ressaltamos que a expectativa da pesquisa é contribuir com a formação do Controller, alinhada às demandas do mercado de trabalho, repercutindo indiretamente no desempenho deste profissional.

Por fim, é importante ratificar que as informações fornecidas serão utilizadas para fins estritamente científicos, em momento algum serão divulgados dados individualizados.

Desde já, grato pela atenção,

Roberto José Vieira de Sousa Lima

Mestrando do Programa Multi-Institucional e Inter-regional de Pós-Graduação em Ciências Contábeis - UnB, UFPB e UFRN

Dra. Aneide Oliveira Araujo

Professora do Programa Multi-Institucional e Inter-regional de Pós-Graduação em Ciências Contábeis - UnB, UFPB e UFRN 


\section{BLOCO 01: Competência dos Controllers em escala de importância.}

01. Como você avalia o grau de importância das competências descritas abaixo para o desempenho do cargo de Controller?*

Assinale articulando a competência (linhas) com sua avaliação (colunas).

* Marcar apenas uma opção por linha.

\begin{tabular}{|l|l|l|l|l|l|l|}
\hline Competências & $\begin{array}{c}\text { Não sei } \\
\text { avaliar }\end{array}$ & $\begin{array}{c}\text { Nenhuma } \\
\text { Importância }\end{array}$ & $\begin{array}{c}\text { Pouca } \\
\text { Importância }\end{array}$ & Importante & $\begin{array}{c}\text { Muito } \\
\text { Importante }\end{array}$ & Indispensável \\
\hline Autocontrole & & & & & & \\
\hline $\begin{array}{l}\text { Capacidade } \\
\text { analítica }\end{array}$ & & & & & & \\
\hline $\begin{array}{l}\text { Contabilidade e } \\
\text { finanças }\end{array}$ & & & & & & \\
\hline Empreendedora & & & & & & \\
\hline $\begin{array}{l}\text { Ferramentas de } \\
\text { controle }\end{array}$ & & & & & & \\
\hline $\begin{array}{l}\text { Gestão da } \\
\text { Informação }\end{array}$ & & & & & & \\
\hline $\begin{array}{l}\text { Conhecimento } \\
\text { Legal }\end{array}$ & & & & & & \\
\hline $\begin{array}{l}\text { Ouvir } \\
\text { eficazmente }\end{array}$ & & & & & & \\
\hline Planejamento & & & & & & \\
\hline $\begin{array}{l}\text { Relacionamento } \\
\text { externo }\end{array}$ & & & & & & \\
\hline $\begin{array}{l}\text { Trabalho em } \\
\text { Equipe }\end{array}$ & & & & & & \\
\hline $\begin{array}{l}\text { Visão } \\
\text { Estratégica }\end{array}$ & & & & & & \\
\hline
\end{tabular}




\section{BLOCO 02: Experiências essenciais no desenvolvimento de um Controller.}

02. Ordene as vivências a seguir pelo grau de importância que elas têm para o desempenho de seu trabalho como Controller. *

$\left(1^{\circ}=\right.$ Mais importante. $5^{\circ}=$ Menos importante $)$.

* Marcar apenas uma opção por linha.

\begin{tabular}{|l|l|l|l|l|l|}
\hline & $\mathbf{1}^{\mathbf{0}}$ & $\mathbf{2}^{\mathbf{o}}$ & $\mathbf{3}^{\mathbf{0}}$ & $\mathbf{4}^{\mathbf{0}}$ & $\mathbf{5}^{\mathbf{0}}$ \\
\hline Educação formal (escolar, básica) & & & & & \\
\hline Formação inicial (graduação) & & & & & \\
\hline $\begin{array}{l}\text { Formação contínua (pós-graduação, } \\
\text { treinamentos) }\end{array}$ & & & & & \\
\hline $\begin{array}{l}\text { Experiências profissionais (estágios, } \\
\text { empregos anteriores) }\end{array}$ & & & & & \\
\hline $\begin{array}{l}\text { Experiências sociais (intercâmbio, } \\
\text { network) }\end{array}$ & & & & & \\
\hline
\end{tabular}

03. Da lista abaixo, selecione os 05 (cinco) conteúdos de disciplinas da sua formação (inicial e/ou contínua) mais importantes para o desempenho de seu trabalho como Controller. *

* Marque todas que se aplicam.

( ) Auditoria

( ) Contabilidade

( ) Custos

( ) Direito

( ) Finanças

( ) Gestão da produção

( ) Gestão de pessoas

( ) Língua estrangeira

( ) Logística

( ) Orçamento

( ) Planejamento estratégico

( ) Sistemas de informação

( ) Tributos

( ) Outro 
04. Quais das experiências profissionais listadas abaixo contribuíram decisivamente para você ter se tornado um(a) Controller? *

Assinale cada experiência articulando a área de atuação (linhas) e o nível do cargo (colunas).

* Marcar apenas uma opção por linha.

\begin{tabular}{|l|l|l|l|l|l|}
\hline Área & $\begin{array}{c}\text { Não se } \\
\text { aplica }\end{array}$ & Estágio & Trainee & Operacional & Gerencial \\
\hline Auditoria & & & & & \\
\hline $\begin{array}{l}\text { Contabilidade } \\
\text { financeira }\end{array}$ & & & & & \\
\hline $\begin{array}{l}\text { Contabilidade } \\
\text { gerencial }\end{array}$ & & & & & \\
\hline Controladoria & & & & & \\
\hline Custos & & & & & \\
\hline Financeiro & & & & & \\
\hline Produção & & & & & \\
\hline $\begin{array}{l}\text { Sistemas de } \\
\text { informação }\end{array}$ & & & & & \\
\hline Tributário & & & & & \\
\hline
\end{tabular}

05. Qual seria a sua experiência profissional (área de atuação e cargo) mais valiosa para o desempenho de sua função como Controller? Por quê? 


\section{BLOCO 03: Perfil do respondente.}

06. $\operatorname{Sexo} *$

* Marcar apenas uma opção.

( ) Feminino

( ) Masculino

07. Faixa etária *

* Marcar apenas uma opção.

( ) 29 anos ou menos

( ) De 30 a 39 anos

( ) De 40 a 49 anos

( ) 50 anos ou mais

08. Tempo de carreira profissional total $*$

* Marcar apenas uma opção.

( ) 5 anos ou menos

( ) De 6 a 10 anos

( ) De 11 a 15 anos

( ) De 16 a 20 anos

( ) Mais de 20 anos

09. Tempo de carreira como Controller *

* Marcar apenas uma opção

( ) 5 anos ou menos

( ) De 6 a 10 anos

( ) De 11 a 15 anos

( ) De 16 a 20 anos

( ) Mais de 20 anos 
10. Nível hierárquico, como Controller, na empresa atual (ou última empresa) *

* Marcar apenas uma opção

( ) Diretoria

( ) Gerência

( ) Supervisão / Coordenação

( ) Operacional

11. Formação de ensino superior *

(pode assinalar mais de uma opção)

* Marque todas que se aplicam.

( ) Administração

( ) Ciências Contábeis

( ) Direito

( ) Economia

( ) Engenharia de Produção

( ) Outro:

12. Área de formação de pós-graduação.

Articular a área de conhecimento (linhas) e o tipo de curso (colunas).

(Pode assinalar mais de uma opção por linha)

\begin{tabular}{|l|l|l|l|l|l|}
\hline & $\begin{array}{c}\text { Especialização } \\
\text { Lato Sensu }\end{array}$ & $\begin{array}{c}\text { Especialização } \\
\text { MBA }\end{array}$ & $\begin{array}{c}\text { Mestrado } \\
\text { Profissional }\end{array}$ & $\begin{array}{c}\text { Mestrado } \\
\text { Acadêmico }\end{array}$ & Doutorado \\
\hline Administração & & & & & \\
\hline Auditoria & & & & & \\
\hline Ciências Contábeis & & & & & \\
\hline Controladoria & & & & & \\
\hline Economia & & & & & \\
\hline $\begin{array}{l}\text { Engenharia de } \\
\text { produção }\end{array}$ & & & & & \\
\hline Finaças & & & & & \\
\hline Gestão de pessoal & & & & & \\
\hline $\begin{array}{l}\text { Sistemas de } \\
\text { Informação }\end{array}$ & & & & & \\
\hline Tributária & & & & & \\
\hline Outro & & & & & \\
\hline
\end{tabular}


13. Domínio de língua estrangeira *

(pode assinalar mais de uma opção)

* Marque todas que se aplicam.

( ) Chinês

( ) Espanhol

( ) Francês

( ) Inglês

( ) Nenhuma das alternativas

( ) Outro:

14. Setor de atividade da empresa atual (ou última empresa) *

* Marcar apenas uma opção

( ) Agropecuário

( ) Comércio

( ) Financeiro

( ) Indústria

( ) Serviço

( ) Terceiro Setor

( ) Outro:

14. UF onde o respondente trabalha atualmente (ou última empresa) *

* Marcar apenas uma opção

( ) Acre

( ) Alagoas

( ) Amapá

( ) Amazonas

( ) Bahia

( ) Ceara

( ) Distrito Federal

( ) Espirito Santo

( ) Goiás

( ) Maranhão

( ) Mato Grosso

( ) Mato Grosso do Sul 
( ) Minas Gerais

( ) Pará

( ) Paraíba

( ) Paraná

( ) Pernambuco

( ) Piauí

( ) Rio de Janeiro

( ) Rio Grande do Norte

( ) Rio Grande do Sul

( ) Rondônia

( ) Roraima

( ) Santa Catarina

( ) São Paulo

( ) Sergipe

( ) Tocantins

16. Número de funcionários no Brasil da empresa atual (ou última empresa)*

* Marcar apenas uma opção

( ) 50 funcionários ou menos

( ) De 51 a 100 funcionários

( ) De 101 a 250 funcionários

( ) De 251 a 500 funcionários

( ) De 501 a 1.000 funcionários

( ) Mais de 1.000 funcionários 